University of Rhode Island

DigitalCommons@URI

Open Access Dissertations

1976

\title{
Analysis of Chilean Fisheries Expansion Alternatives
}

Luis Alberto Adriasola

University of Rhode Island

Follow this and additional works at: https://digitalcommons.uri.edu/oa_diss

\section{Recommended Citation}

Adriasola, Luis Alberto, "Analysis of Chilean Fisheries Expansion Alternatives" (1976). Open Access Dissertations. Paper 497.

https://digitalcommons.uri.edu/oa_diss/497

This Dissertation is brought to you for free and open access by DigitalCommons@URI. It has been accepted for inclusion in Open Access Dissertations by an authorized administrator of DigitalCommons@URI. For more information, please contact digitalcommons-group@uri.edu. 


\section{ANA LYSIS OF CHILEAN FISHERIES}

EXPANSION ALTERNATIVES

By

LUIS ALBERTO ADRIASOLA

A DISSERTATION SUBMITTED IN PARTIAL FULFILLMENT OF THE REQUIREMENTS FOR THE DEGREE OF

DOCTOR OF PHILOSOPHY

IN

ECONOMICS

MARINE RESOURCES OPTION

UNIVERSITY OF RHODE ISLAND

1976 


\section{DOCTOR OF PHILOSOPHY DISSERTATION}

OF

LUIS ALBERTO ADRIASOLA

Approved:

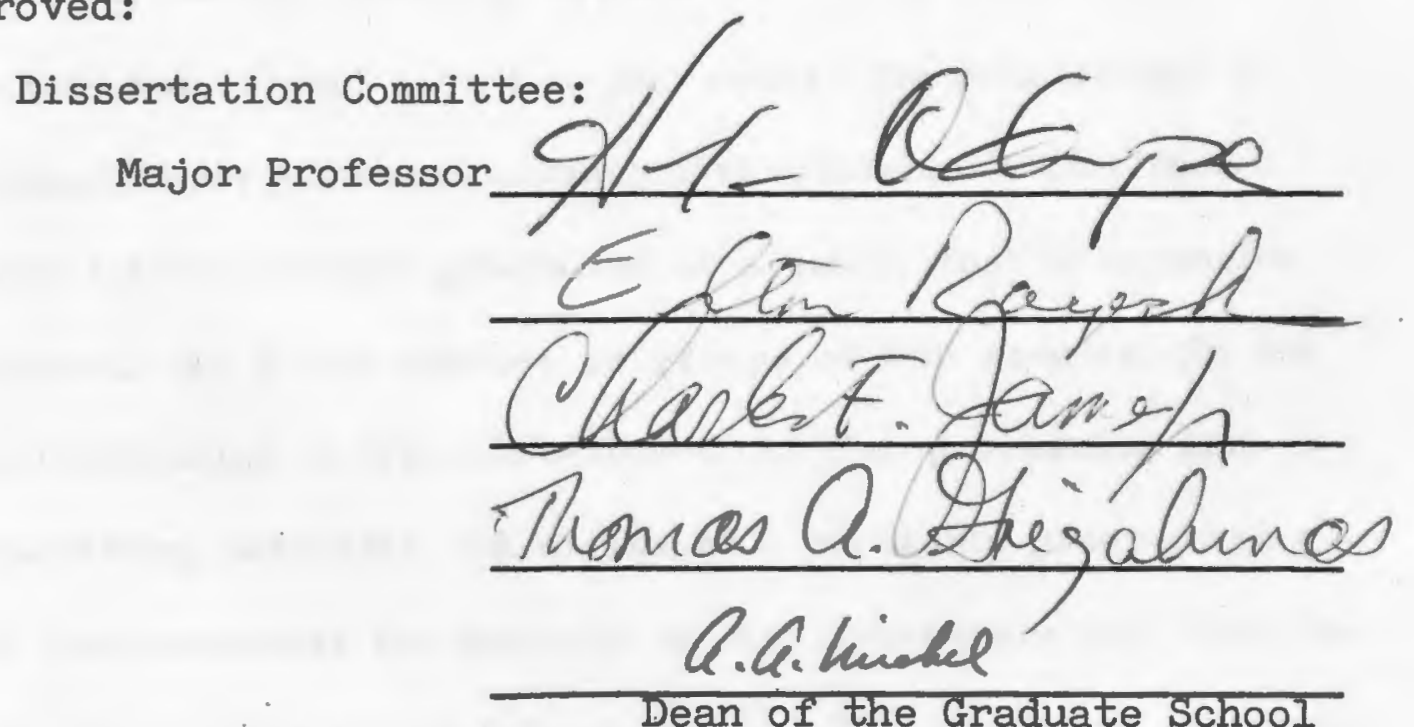

UNIVERSITY OF RHODE ISLAND 


\section{A BSTRACT}

This dissertation investigates the expansion of the Chilean fisheries focusing on the processing and marketing activities for seven fish species that represent over $90 \%$ of the catch and for two groups of the remaining fish species. A review is made of the current condition of the Chilean fisheries, its expansion potential and some possible expansion alternatives. It is established that there exists an ample potential for the expansion of the catch and physical production of fishery commodities. A model is developed to characterize the economic system formed by the fisheries extractive and related activities and assess the profitability of investment under different expansion alternatives. This model includes (a) the random generation of a catch, that is normally distributed, for 9 fish species or groups of fish species; (b) the optimal allocation of $\mathrm{fish}$ harvested to $25 \mathrm{fish}$ processing and 125 marketing activities, by means of a separable programming model that simulates the behavior of fish processors and distributors in the country's five fishing zones. The results of the model of the fishery economic system indicate static rates of return on investment in the different zones and determines the intertemporal internal rate of return for the investment in different zones.

The major conclusion of the study is that it is economically feasible to expand the output of both processed and unprocessed fishery commodities, particularly in Zone II. 
The study concludes with a discussion of future directions for research, including improvement of the quality of the basic data used, and to a lesser degree refinement of the model, to improve the accuracy and reliability of the results. 
To my parents,

my wife

and

our children 


\section{A CKNOW LEDGEMENTS}

I am grateful to the members of my program committee, Professors Harlan C. Lampe, Charles F. James, Elton T. Rayack and Spiros Constantinides, for their continuous interest in my program and dissertation research. Important contributions to the improvement of the form of the final report were made by them and by the other members of the examining committee, Professors Lewis Alexander and Tomas Grigalunas. Whatever good qualities this work may possess are mainly due to the gentle and uncompromising guidance received from the Chairman of my program, Professor Lampe. Thanks are first and foremost due to him.

Programming assistance from the computer Laboratory staff, and from Professor Lampe, who guided the development of his linear programming algorithm into a separable programming subroutine, are gratefully acknowledged. Thanks are also due to Professor G. Booth from U.R.I. School of Business Administration for allowing the use of his internal rate of return subroutine.

The support and encouragement received from my colleagues at the Department of Resource Economics, University of Rhode Island; Escuela de Pesquerías y Alimentos, Universidad Católica de Valparaíso; and Centro de Planeamiento, Departamento Industrias, Universidad de Chile, provided a continuous incentive for the completion of this work. In the impossibility of mentioning them all, I single out Lars Vidaeus from REN/U.R.I.; Pablo Herrera from EPA/UCV, 
and Oscar Barros from CEPLA/U.Ch. Thanks are due to them and to the many Chilean organizations that gave free access to their information (IFOP, SAG, CORFO, Pesquera Chile-Arauco, etc.).

Finally my thanks are due to Mrs. Sue Rubinsky for typing the early drafts, and to my wife Verónica for typing the final version in addition to her normal secretarial and uxorial duties. The completion of this dissertation has been in fact possible only through her understanding, unwaivering support and continuous encouragement.

Monetary and logistic support that permitted the research on which this dissertation is based was received from the University of Rhode Island's International Center for Marine Resources Development and Department of Resource Economics. Support for internal travel in Chile was received from the Escuela de Pesquerías y Alimentos, Universidad Católica de Valparaíso, and from the Centro de Planeamiento, Departamento Industrias, Universidad de Chile. A generous travel invitation extended by the Chilean Office of the United States Agency for International Development, permitted the international travel required for the completion and defense of this dissertation. 


\section{TABLE OF CONTENTS}

Chapter

INTRODUCTION.

I. THE CHILEAN FISHERIES: A CASE FOR DEVELOPMENT...... 8

1. The Chilean Fishery Resources.................... 8

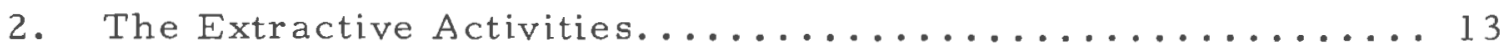

3. Marketing and Distribution of Fishery Products......... 17

Fresh Fish Marketing...................... 17

Processing and Distribution of Frozen and

Canned Fishery Products..................... 23

Marketing and Exports of Fishmeal and Oil.......... 23

4. The Fisheries and Related Activities as An Economic

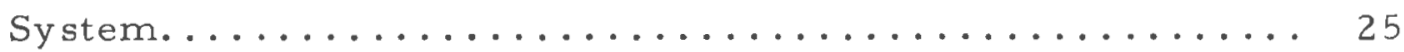

Constraints on Fisheries Performance.............. 27

5. Expansion Alternatives for the Chilean 27

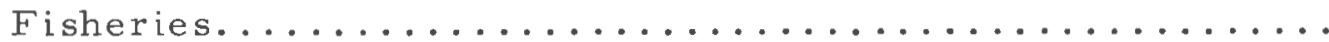

Expansion of the Catch from Natural Resources...........28

Fish and Shellfish Cultures.................... 30

Utilization of Fishery Resources................. 3 I

Improvement in the Utilization of Currently

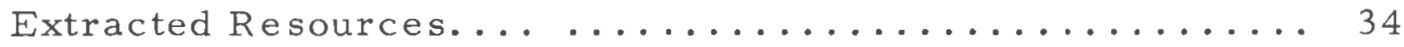

Alternatives for Expansion. .................. 38

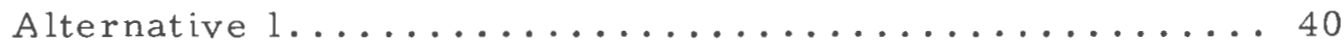

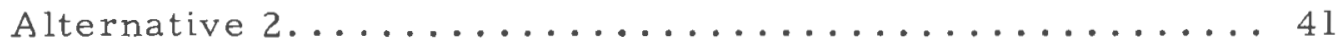


TABLE OF CONTENTS (Continued)

Chapter

Page

II. SIMULATION OF ECONOMIC PERFORMANCE:

DESCRIPTION OF THE MODEL.............. 42

Section 1 - - The Stochastic Elements......... 44

Section 2 - Simulation of the Extractive Activity.... 45

Generation of the National Catch........... 45

Simulation of Zonal Catch............. 47

Section 3 -- Simulation of Processing and

Distribution...................... 49

Section 4 -- Optimization of Fish Processing and

Fresh Fish Marketing................ 52

Estimation of Costs................. 52

Estimation of Prices.................... 53

Estimation of Net Revenue Functions......... 55

Allocation of Fish Resources............. 59

Section 5 - Evaluation of Performance........ 66

.III. SIMULATION OF ECONOMIC PERFORMANCE:

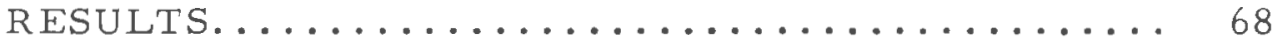

1. Initial and Projected Conditions............ 68

2. Short-Run Performance.................69 69

3. Long-Run Performance................ 77 
TABLE OF CONTENTS (Continued)

Chapter

Page

4. Discussion of Results.................. 80

Output Behavior................... 80

Price Behavior...................... 82

Net Revenues and Return on Investment....... 86

Interpretation of the Shadow Prices.........886

Long-Run Results.................. 86

Sensitivity Analysis Results..............89

5. Accuracy and Reliability of Results..........91

IV.CONCLUSIONS AND POLICY IMPLICATIONS. . . . . . . . 93

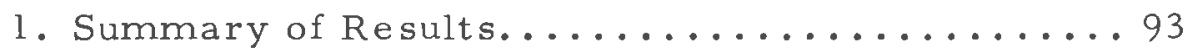

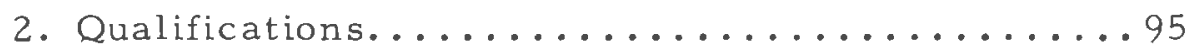

3. Policy Ramifications................... 96

4. Limitations of the Present Study........... 97

5. Extension of Economic Research of the

Production of Fishery Commodities in Chile.....999

BIBLIOGRAPHY ........................ 101

APPENDICES

A. Marine Species in Chilean Waters

B. Prices and Costs for Chilean Fishery Commodities

C. List of Separable Programming Variables

D. Zonal Net Revenue Functions 
TABLE OF CONTENTS (Continued)

E. Output Under Zonal Objective Functions

F. Net Revenues and ROI Under Zonal OB Function 
1. Chilean Landings, 1930-1974, in Metric Tons of $\mathrm{Fish}$ and Shellfish.................. 3

2. Fleet Distribution - - Industrial Sector.......... 14

3. Artisanal Fishing Activities in Chile........... 16

4. Extraction and Utilization of Chilean Fishery

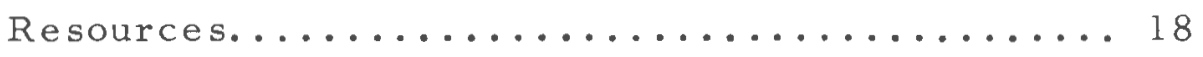

5. Selected Measures of Chilean Landings 1970-1973 19

6. Selected Measures of Chilean Fishery Production

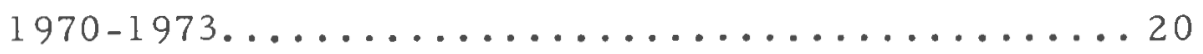

7. Average Landings, Current and Potential......... 29

8. Suitability of Conventional Underexploited Marine

Species for Different Forms of Marketing........ 33

9. Utilization of Chilean Fishery Resources

$(\%$ of each species destined to each use)....... 35

10. Fish Contribution to Product Value in Alternative

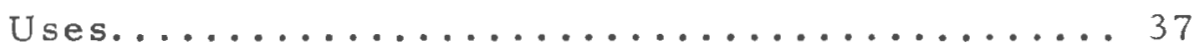

11. Fish Catch Frequency Distribution Parameters.... 46

12. Catch Distribution by Zone................ 48

13. Total Net Revenue (in US\$) and Associated

Outputs for Zonal Production of Selected Fishery

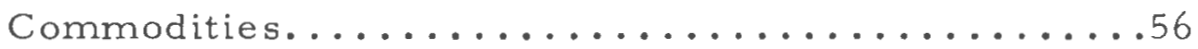

14. Current and Projected Zonal Capacities for the 
LIST OF TABLES (Continued)

Table

Page

15. Estimated Investment in the Production of

Fishery Commodities in US $\$$ of $1975 \times 1000 \ldots \ldots 70$

16. Separable Programming Results - Summary of

Annual Outputs by Commodity - Alt. A......... 72

16. Separable Programming Results: Summary of

Annual Outputs by Commodity - Alt. B.......... 73

17. Separable Programming Results: Net Revenues

and Return on Investment by Zone and Year...... 74

18. Separable Programming Results: Slack Available

and Associated Shadow Prices of Constraints.......75

19. Summary of Yearly Performance.............. 76

20. Ten Year Output of Fishery Commodities and

Associated Employment as Function of Output..... 77

21. Summary of Annual Results Capacity and Output

and Employment as a Function of Capacity.........78

22. Long-Run Return on Investment................ 79

23. Impact of Capacity Change on National Output.......81

24. Separable Programming Results: Summary of

Annual Output and Prices for Selected Commodities 83 
FIGURE S

Figure

Page

1. Chilean Landings of Fish and Shellfish........

2. Chilean Fishery Zones.................

3. Marketing Channels for Fresh Fishery Products..... 21

4. Marketing Channels for Processed Fishery

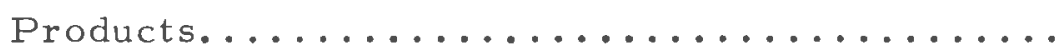

5. Cost Curves for Canned Production............ 54

6. Separation of Net Revenue Function Canned Products...................... 60

7. Flow Chart - Simulation of Fisheries Operation... 67 
INTRODUCTION

The current state of the Chilean fisheries, as characterized by its performance since 1965, gives a clear indication that its development is at a point of stagnation. This poses an important challenge to this nation of over 10,000,000 inhabitants, where, despite the access to marine food resources, a significant part of the population suffers from some degree of malnutrition.

An indication of the evolution of the primary fishing activities in Chile is presented in Figure 1 and Table 1. It shows that until 1960 the average yearly catch did not exceed 300,000 metric tons. Spurred by the success of the Peruvian anchoveta fisheries, and by incentives provided by the Chilean government, mainly in the form of tariffs and tax exemptions and subsidized credits, a number of enterprises, both publicly and privately owned, started the exploitation of the anchoveta resource off the Chilean coast. As a result of this effort the sector had an explosive rate of physical growth of nearly $35 \%$ per year during the period between 1960 and 1965. After 1965, and during the last ten years, the Chilean catch has fluctuated around 1,000,000 metric tons, giving the impression that the limit of the sustainable yield of Chilean fishery resources has been reached.

Contrasting with this evidence are the findings of stock assessment research carried out by the Instituto de Fomento Pesquero (IFOP), the national agency in charge of these investigations, that 
METRIC

TON.

$\times 1000$

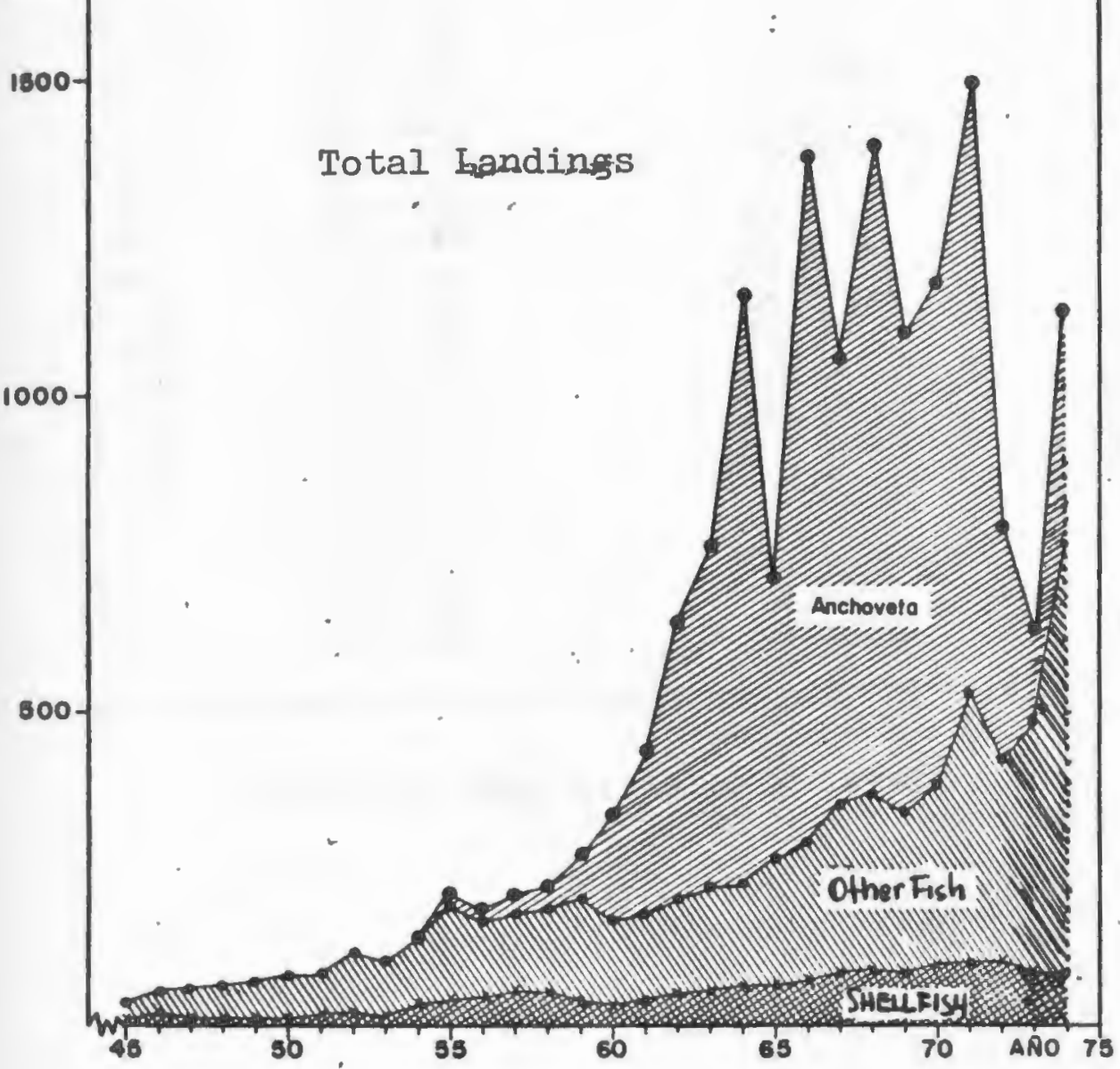

Eigure 1 Chilean Landings of Fish and Shellfish

Source: Servicio Agricola y Ganadero, Division de - Caza y Pesca 
Table 1 Chilean Landings, 1930-1974, in Metric Tons of Fish and Shellfish

\begin{tabular}{|c|c|c|c|}
\hline Year & Fish & Shellfish & $\begin{array}{l}\text { Total or Aver Y } \\
\text { Landings per Yeis }\end{array}$ \\
\hline $\begin{array}{l}1930-34 \\
1935-39 \\
1940-44 \\
1945-59 \\
1950-54 \\
1955-59 \\
1960 \\
1961 \\
1962 \\
1963 \\
1964 \\
1965 \\
1966 \\
1967 \\
1968 \\
1969 \\
1970 \\
1971 \\
1972 \\
1973 \\
1974\end{array}$ & $\begin{array}{r}15,573 \\
26,097 \\
28,044 \\
45,180 \\
85,647 \\
173,846 \\
304,666 \\
338,810 \\
586,434 \\
705,682 \\
1,093,561 \\
642,957 \\
1,309,139 \\
969,011 \\
1,291,041 \\
1,009,840 \\
1,082,252 \\
1,389,022 \\
690,407 \\
581,417 \\
1,047,808\end{array}$ & $\begin{array}{r}7,748 \\
7,393 \\
9,607 \\
16,621 \\
24,011 \\
43,976 \\
35,037 \\
40,932 \\
52,129 \\
56,538 \\
67,703 \\
65,782 \\
74,270 \\
83,814 \\
84,845 \\
85,309 \\
99,069 \\
97,901 \\
101,496 \\
82,593 \\
80,432\end{array}$ & $\begin{array}{r}23,321 \\
33,490 \\
37,651 \\
61,301 \\
109,653 \\
222,332 \\
339,703 \\
429,751 \\
630,563 \\
762,220 \\
1,161,264 \\
708,739 \\
1,383,409 \\
1,052,825 \\
1,375,836 \\
1,095,149 \\
1,181,821 \\
1,433,923 \\
791,903 \\
664,010 \\
1,128,240\end{array}$ \\
\hline
\end{tabular}

Source: SAG, Division de Pesca. 
estimate the maximum sustainable yield (M.S.Y.) of the Chilean fisheries at 2,000,000 metric tons per year. 1 Arguments are made for the expansion of the Chilean fisheries based on this evidence. The fact that expansion has not come about is used as grounds to contend that either the physical potential does not really exist or is not by itself enough to make the expansion of the fisheries sector as attractive as the expansion of other sectors of the economy.

The Chilean government, accepting IFOP's estimates of available resources, has postulated the following objectives for fisheries development: 2

(1) to make the fisheries (a) a source of sustained food reserves for the country (b) an important factor of the national economy that may permit the satisfaction of the basic needs of a constantly increasing (domestic) population and may contribute to the solution of the world food crisis. Towards this end, the utilization of current catches must be

\section{1}

Oscar F. Guzmán "Situación y Perspectivas de la Explotación de los Principales Recursos Pesqueros de Chile", in Seminario Sobre las Perspectivas de Desarrollo del Sector Pesquero Chileno, Viña del Mar, Septiembre 1974, Asociación de Profesionales Pesqueros de Chile, Escuela de Pesquerías y Alimentos, Universidad Católica de Valparaíso, 1975.

2

José T. Merino "Política Pesquera Nacional", issued at the inauguration of the Month of the Sea, San Vicente, Talcahuano, May 5, 1975. Printed by Instituto de Fomento Pesquero, Santiago, 1975 (author's translation). 
improved and subsequently the extraction of currently exploited species increased rationally in the cases where this is possible and the exploitation of potential resources and culture must be encouraged.

(2) to expand the per capita consumption of fishery products as a solution to the food and nutrition problem of the (domestic) population, through campaigns to promote the consumption of these products, in fresh or processed form.

(3) to make a positive impact on the balance of trade, generating a market for Chilean fishery products of quality standards that are internationally accepted.

(4) to generate significant employment opportunities, through the establishment of units linked to the marine and continental fisheries that are effectively productive.

The State, through its pertinent agencies, will have the responsibility to (a) insure a rational exploitation of the fishery resources, (b) direct and supervise the development of the sector, (c) plan fisheries economic activity giving due consideration to the right of private activity but will not accept that the renewable natural resources be irrationally exploited.

The above stated objectives may be summarized as:

1. The maximization of the sustained production of food from fishery resources, both for internal consumption as 
well as exports;

2. The maximization of productive employment opportunities for the population.

These two goals are different and are not normally reached simultaneously. Under the current condition of the Chilean economy, however, there appears to exist a relative abundance of labor, making the second objective not inconsistent with the first. The relative abundance of natural resources on the other hand permits the achievement of both objectives at a relatively low opportunity cost to the national economy.

Clearly though, even after accepting IFOP's assessment of potential physical yields, there remain questions to be answered concerning the economic feasibility of expanding the production of fishery commodities, and on the implications of that expansion. This study will seek to answer two of the most important among these questions, i.e., (1) Whether there exists, in economic terms, a potential for fisheries development in Chile, and (2) What are some of the implications of the expansion of the fisheries output. To assess the economic potential, the fisheries economic system will be assumed to behave as if it were maximizing profits, knowing fully well it may not be entirely so, as in reality the system is mixed, and the net revenues associated with that behavior will be evaluated.

The internal rate of return on investment and the net benefit 
to the economy will be used to evaluate alternative approaches to the expansion of the sector. A limited set of alternatives including

a) the current conditions

b) expanded fresh and fishmeal capacities

c) expanded fresh, frozen, canning and fishmeal capacities

will be used to test the performance of the system under an expanded catch of marine fish species which may be as large as twice the current catch.

The first Chapter of this study includes a review of the current situation of the Chilean fisheries, an examination of the limits that constrain fisheries expansion, and the outline of two expansion alternatives. Chapter II presents a methodology of analysis to be used to evaluate the performance of the fisheries economic system under the expanded catch. Chapter III presents the results of the analysis performed and Chapter IV, the conclusions and a discussion of their implications and policy ramifications. 


\section{CHAPTER I}

THE CHILEAN FISHERIES: A CASE FOR DEVELOPMENT

The development of a fisheries requires the consideration of a number of factors. The most important are:

a) the approximate location and abundance of resources and the nature of their exploitation. These factors determine the characteristics and size of the fleet required for their extraction.

b) the nature of the marketing system and the alternative adjustments required from it to absorb the increased catch.

The objectives of this Chapter are to describe the Chilean fisheries and related activities, to characterize the operation of these activities in an economic system, and to outline alternatives for the expansion of the contribution of the sector to the national economy.

\section{The Chilean Fishery Resources.}

Chile has over 2,500 miles of mainland sea coast, and claims a 200-mile fishery zone. Although the narrowness of the continental shelf off the Chilean coast limits in part the productivity of the primary fishing activity, it is still considerable enough to place Chile among the ten major fishing nations of the world.

The vast physical extent to the Chilean fishing grounds can be divided into six zones. These are shown in Figure 2. The first fishing zone runs from the border with Perú to south of Taltal and includes the ports of Arica, Iquique, Tocopilla, Mejillones, 


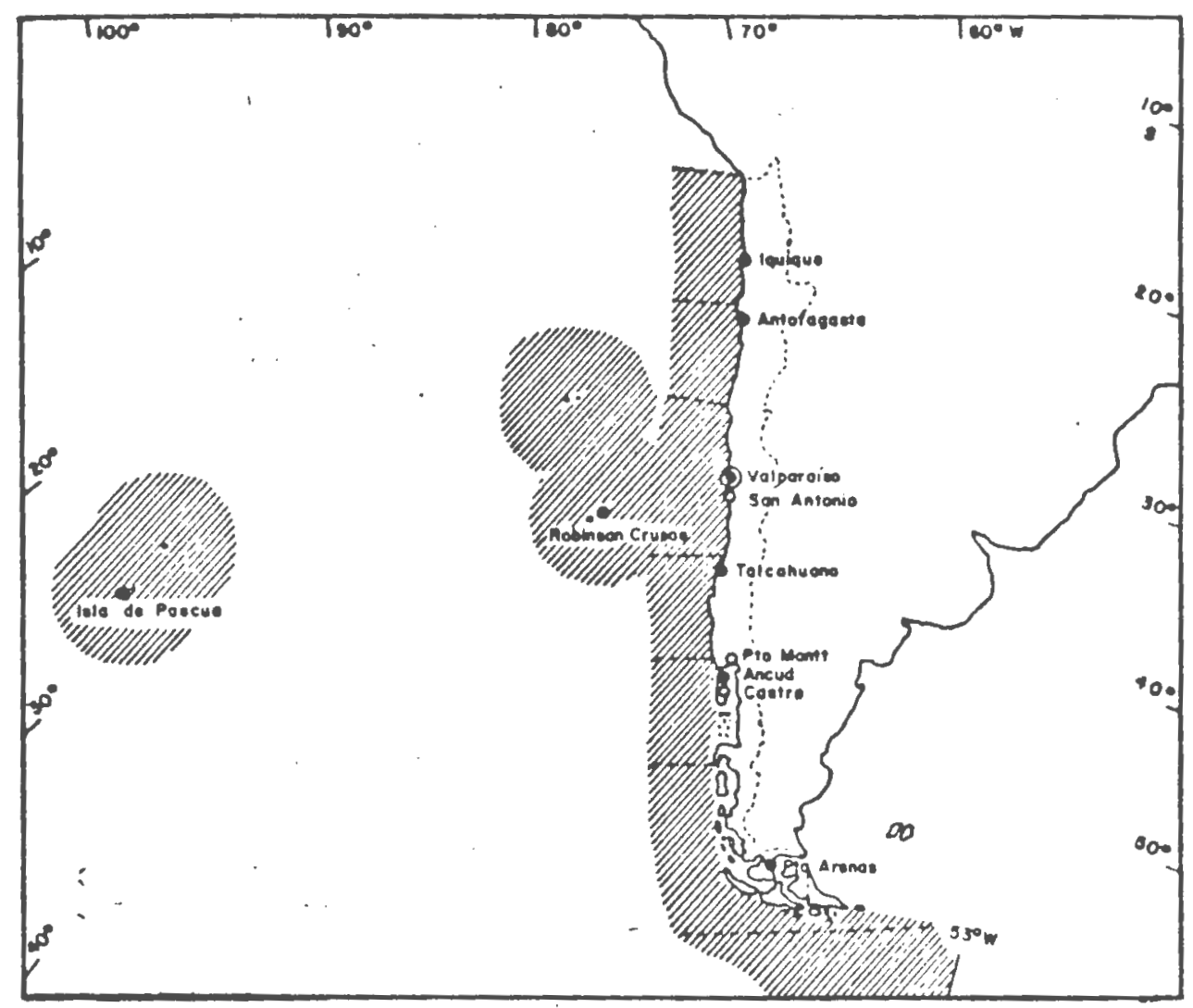

Figure 2 Chilean Fishery Zones I to VI.

Source: Patricio Arana "Investigación Pesquera en Chile," in Seminario sobre Perspectivas, p. 87. 
Antofagasta, and Taltal. The main conventional resources in this zone are the pelagic species -- anchoveta lengraulins ringen anchovy), jurel (trachurus murphyi - mackerel), and sardina (strangomera benticki, sardinops sagax musica - - pilchard).

Potential resources yet unexploited include mainly the agujilla species (scomberesox stolatus - saury), also a pelagic fish. The anchoveta and sardina resources of this zone have been heavily exploited over the past ten years.

The second fishery zone runs from south of the port of Taltal and includes the ports of Coquimbo and the fishing villages Guanaqueros and Tongoy. The main fishery resources under exploitation in this zone are again the pelagic species jurel, anchoveta and sardinas, although with a lower intensity. The agujilla species is available in greater concentration in this zone.

The third fishery zone runs from the fishing village of Los Vilos, about 150 miles south of Coquimbo, to the Golfo de Arauco, and includes the ports of Quintero, Valparaíso, San Antonio, Constitución, Tomé, Talcahuano, and San Vicente. Main resources in this zone, among the pelagic species, are anchoveta, jurel, sardina (clupea fueguensia - herring), and the dermersal species merluza (merluccius gayi gayi - hake) and congrios (genypterus - cuskeel). Also important are the crustaceans camarón (heterocarpus reedi shrimp) and langostino (pleuroncodes monodon). A characteristic of this zone is the openness of the sea, restricting bad weather fishing operations to sheltered waters for all but vessels of large 
displacement. Even under this condition, the pressure on some species, particularly crustaceans, is fairly intense.

The fourth fishery zone runs from Golfo de Arauco to Puerto Montt and includes the ports of Valdivia, Corral, Puerto Montt, Ancud and Calbuco. The main species under exploitation in this area include the de m ersal species merluza and the variety of mollusks (ameghinamia antigua, mesoderma donacium - clams; mytilus edulis, aulacomya ater - mussels.). Unexploited species include mainly merluza de cola (macrurus magellanicus - grenadier). Climatic conditions in this zone are quite severe, and road access to the coast is not as available as in the nortern and central zones. The fifth fishery zone runs from the south of Ancud Island to the Golfo de Penas and includes mainly the port of Puerto Aguirre. The fisheries in this zone present a marked difference between the open seas and the sheltered waters. In the open seas, demersal species, led by the merluzas and congrios, are predominant, although there are also important pelagic resources of which the mackerels are the most important. While fishing operations in the open seas are often impeded by the severe weather, extractive activities in the waters of the channels and fiords can be carried out under almost any weather conditions even with small vessels. The resources found in sheltered waters are mainly shellfish cholgas, choritos, almejas, etc., while the largest concentrations of merluza de cola are found in the open seas. 
The sixth fishery zone runs from the Golfo de Penas to the Cabo de Hornos and includes the ports Puerto Natales, Punta Arenas and Porvenir. The open sea fishery resources in this zone are quite sparse, while the sheltered waters offer significant amounts of shellfish, mainly mussels.

The Antarctic waters provide little in the way of conventional resources, under climatic conditions that restrict fishing to the three summer months. In these waters, however, lies the most spectacular opportunity for the expansion of the world food supply in the krill (euphausia spp) a loose link in the food chain between plankton and the almost extinct whales. The maximum sustainable yield of this protein rich crustacean is variously assessed at 5 million metric tons per year for the resources in Chilean waters, to 100 million metric tons per year for those in the Antarctic waters 2 as a whole. The extractive as well as processing technology for the commercial exploitation of this fishery are still under development.

A list of the Chilean marine fish species is shown in Appendix A.

1

Guzmán, op. cit., p. 120 .

2

Gordon Campleman, "Chile: The Last Frontier of Fisheries Expansion," Fishing News International, Vol. 14, No.9, September 1975 , p. 37. 
2. The Extractive Activities.

Extractive operations are carried out at two different levels: the industrial and the artisanal. Industrial operations are characterized by the intense use of capital (i.e., large vessels, expensive fishing gear and electronic equipment for fish search and communications to shore, etc.), large scale of operation (volume fishing by trawling, purse seining, etc.), fairly advanced technology, and normally, a close association with fish processing facilities. Industrial fishing accounts for over $92 \%$ of the catch in the country. The set of activities related to each of these levels of operation are often referred to as the artisanal and industrial subsectors of the fisheries sector of the economy.

More than 240 industrial vessels operate out of the 22 fishing ports in the Chilean coast. The main characteristics of the industrial fleet are shown for each fishery zone in Table 2. Over $90 \%$ of the industrial catch goes to fish or crustacean meal production, and the rest to the production of commodities for direct human consumption either in canned or frozen form and not infrequently also to the fresh fish market. 
Table 2 - Fleet Distribution - Industrial Sub Sector

\begin{tabular}{|c|c|c|c|c|c|c|}
\hline $\begin{array}{c}\text { Fishery } \\
\text { Zone }\end{array}$ & Resources & $\begin{array}{l}\text { Type of } \\
\text { Fishing }\end{array}$ & $\begin{array}{l}\text { No. of } \\
\text { Vessels } \\
\end{array}$ & $\begin{array}{l}\text { Hold Capac. } \\
\text { metric tons }\end{array}$ & Main Ports & $\begin{array}{l}\text { State of } \\
\text { Fleet }\end{array}$ \\
\hline $\begin{array}{l}\text { Norte } \\
\text { Grande }\end{array}$ & Pelagic & Purse Seine & 93 & 12,580 & $\begin{array}{l}\text { Arica } \\
\text { Iquique } \\
\text { Antofagasta }\end{array}$ & Good \\
\hline $\begin{array}{l}\text { Norte } \\
\text { Chico }\end{array}$ & Pelagic & Purse Seine & 7 & 580 & $\begin{array}{l}\text { Coquimbo } \\
\text { Caldera }\end{array}$ & Good \\
\hline Centro & $\begin{array}{l}\text { Demersal } \\
\text { Pelagic }\end{array}$ & $\begin{array}{l}\text { Trawl } \\
\text { Purse Seine }\end{array}$ & 28 & 12,563 & $\begin{array}{l}\text { Valparaíso } \\
\text { San Antonio }\end{array}$ & Poor/Fair \\
\hline Sur & $\begin{array}{l}\text { Demersal } \\
\text { Pelagic }\end{array}$ & $\begin{array}{l}\text { Trawl } \\
\text { Purse Seine }\end{array}$ & $\begin{array}{r}22 \\
6\end{array}$ & 1,541 & $\begin{array}{l}\text { Valdivia } \\
\text { Calbuco }\end{array}$ & Fair/Poor \\
\hline $\begin{array}{l}\text { Extremo } \\
\text { Sur }\end{array}$ & Shellfish & Diving & 9 & 419 & Punta Arenas & Fair \\
\hline
\end{tabular}

Source: José Muga et al., "Perspectivas de Desarrollo de la Industria Pesquera en Chile," Seminario Sobre Perspectivas, passim; Comité Sectorial Pesquero, Plan de Desarrollo Industrial Pesquero Discussion Paper, Corporación de Fomento, Santiago 1972, passim. 
The artisanal activities are characterized by a more intense use of labor (small owner operated vessels, often not powered), manual fishing methods, backward technology, and fresh market dependency. This subsector accounts for nearly $8 \%$ of the total catch in the country, almost all of which goes into the fresh market. The artisanal catch constitutes approximately two-thirds of the supply of fresh fishery products and nearly one-half of the total supply of fishery products for direct human consumption (landed weight), with the remaining half marketed in frozen or canned form.

Artisanal fishing methods include mainly the use of hand line, long line and gill nets, for fishing, and diving for the extraction of shellfish. To some extent, the most developed among the artisanal fishermen use purse seines. There are approximately 17,000 fishermen operating some 5,300 vessels out of 189 fishing communities. A breakdown by zone and region of the number of artisanal fishing communities, fishermen and fishing vessels is shown in Table 3 . Because of the differences in the operation of each subsector, i.e., factor intensity, volume vs. selective fishing, integration or lack of integration with processing operations, they have specialized in clearly separate markets. The raw materials for processing plants is supplied by industrial extractive activities, and the fresh fish market is supplied mostly by artisanal fisherm directly or through intermediaries. Accordingly, while the industrial fishery specializes in exploitation of abundant stocks of either pelagic or demersal 
Ilable 3 - Artisanal Fishing Activities in Chile

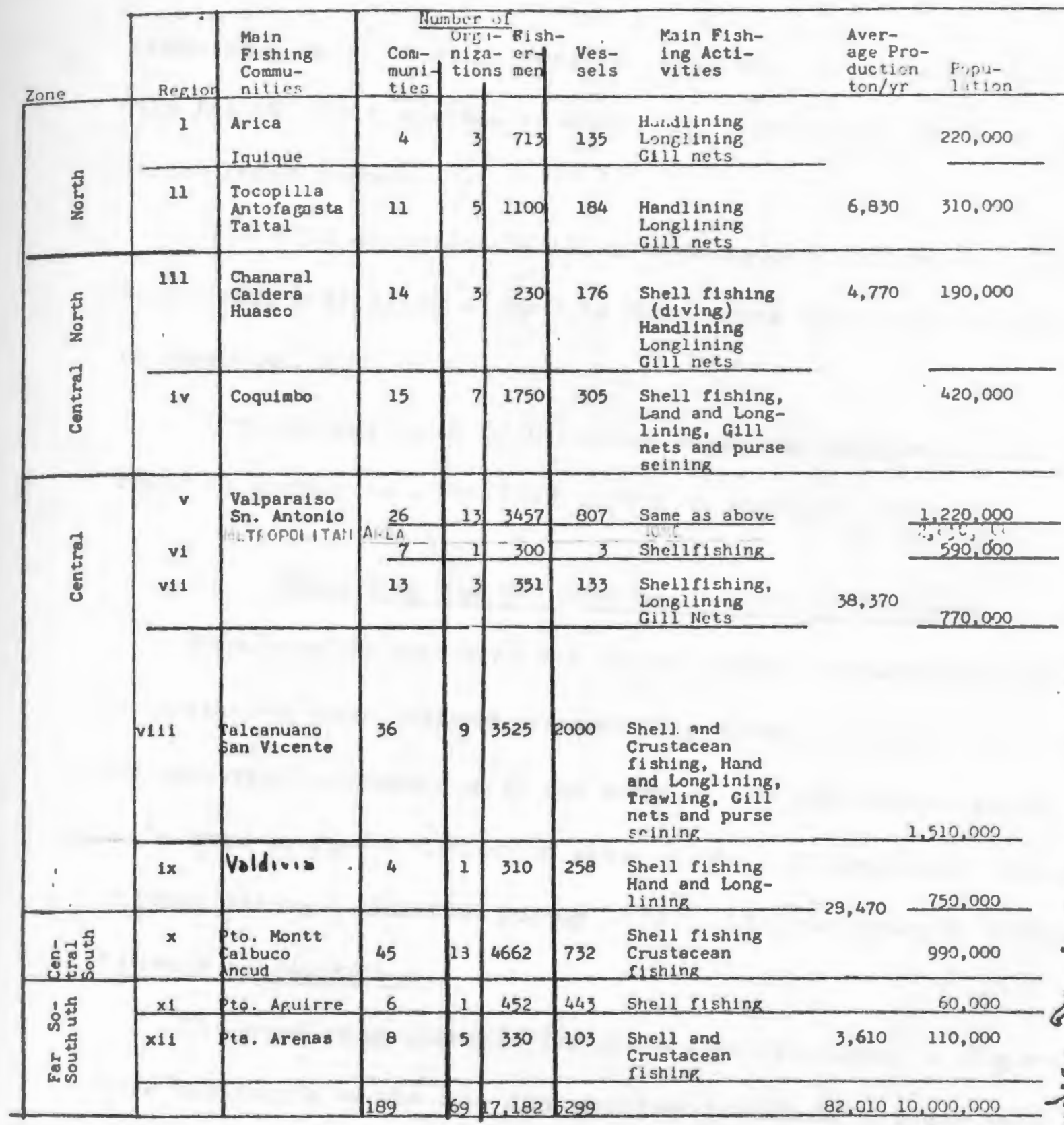

Source: Gonzalo Campos, "Estado Actual de la Pesqueria Artesanal," Paper presented at the $V$ meeting of the Comision Coordinadora de las Investigaclones Cientiflcas-Vina del Mar, October 2975 
resources, most of which goes to reduction, the artisanal fishermen fish for the finer species of white fish, which fetch the best prices in the fresh market.

The total catch during 1974, with its percent distribution for each species or group of species that comes from each subsector is shown in Table 4 .

The average catch of the most important species of fish and shellfish during the 1970-1973 period is shown in Table 5.

3. Marketing and Distribution of Fishery Products.

Fish may be marketed for direct human consumption in fresh or preserved form (canned, frozen, dry salted, smoked, etc.) or for industrial consumption in the form of semi-processed goods to be used in the production of other goods. A breakdown of the Chilean fishery production during 1970 to 1973 is shown in Table 6 . Fresh Fish Marketing

The marketing channels for fresh fish are shown in Figure 3. Over two-thirds of the fish and shellfish marketed in fresh form is supplied by artisanal fishermen. On its way to the consumer this fraction of the supply may pass directly from the fisherman to the household, or through one or two middlemen in a local market to three or more in the case of a great demand center where passage through a large wholesale market (terminal) is required.

Different types of fish merchants buy at the terminals and eventually sell to the consumer either in established retail outlets 
Table 41974 Extraction and Utilization of Chilean Fishery Resources..

\begin{tabular}{|c|c|c|c|c|}
\hline Species & $\frac{\text { Catch Distrik }}{\text { Artisanal }(\%)}$ & $\frac{\text { on }-1974}{\text { Industrial }(\%)}$ & $\begin{array}{l}1974 \text { Catch } \\
\text { Metric Tons }\end{array}$ & $\begin{array}{c}\% \text { Going into } \\
\text { Fishmeal in } 1974\end{array}$ \\
\hline $\begin{array}{l}\text { Anchoveta } \\
\text { Sardina } \\
\text { Jurel } \\
\text { Sierra } \\
\text { Tunidos } \\
\text { Corvina } \\
\text { Merluza } \\
\text { Congrios } \\
\text { Cojinova } \\
\text { Robalo } \\
\text { Other fish }\end{array}$ & $\begin{array}{r}0.5 \\
4.4 \\
8.2 \\
100.0 \\
20.0 \\
48.0 \\
87.5 \\
30.7 \\
86.0 \\
99.8 \\
65.2\end{array}$ & $\begin{array}{l}99.5 \\
95.6 \\
91.8 \\
0 \\
80.0 \\
52.0 \\
12.5 \\
69.3 \\
14.0 \\
0.2 \\
34.8\end{array}$ & $\begin{array}{r}383,374.4 \\
398,824.1 \\
194,383.3 \\
3,826.3 \\
1,345.1 \\
2,377.6 \\
43,067.3 \\
5,349.1 \\
911.6 \\
827.6 \\
13,522.4\end{array}$ & $\begin{array}{c}100 \\
95 \\
91 \\
0 \\
0.1 \\
0 \\
26.3 \\
0 \\
2.6 \\
0 \\
49.8\end{array}$ \\
\hline Subtotal Fish & $\underline{5.3}$ & 94.7 & $1,047,808.5$ & 92.1 \\
\hline $\begin{array}{l}\text { Camaron-Langostino } \\
\text { Other Crustaceans }\end{array}$ & 100.0 & $\begin{array}{c}100.0 \\
0\end{array}$ & $\begin{array}{r}35,047 \cdot 1 \\
2,127 \cdot 6\end{array}$ & ${ }_{0}^{58.2^{*}}$ \\
\hline $\begin{array}{l}\text { Almeja } \\
\text { Cholga/Chorito } \\
\text { Loco } \\
\text { Other Shellfish }\end{array}$ & $\begin{array}{l}100.0 \\
100.0 \\
100.0 \\
100.0\end{array}$ & $\begin{array}{l}0 \\
0 \\
0 \\
0\end{array}$ & $\begin{array}{r}6,938.0 \\
20,91.6 \\
5,928.1 \\
9,482.0\end{array}$ & $\begin{array}{l}0 \\
0 \\
0 \\
0\end{array}$ \\
\hline Subtotal Shellfish & 56.4 & 43.6 & $80,430.4$ & \\
\hline Grand Total & 9.8 & 90.2 & $1,128,238.9$ & \\
\hline
\end{tabular}

Source: SAG Division de Protecion Pesquera "Sintesis Estadistica de Pesca 1974," Santiago, 1975.

*Utilizing the waste from the production of main products. 
Table 5 Selected Measures of Chilean Landings 1970-1973

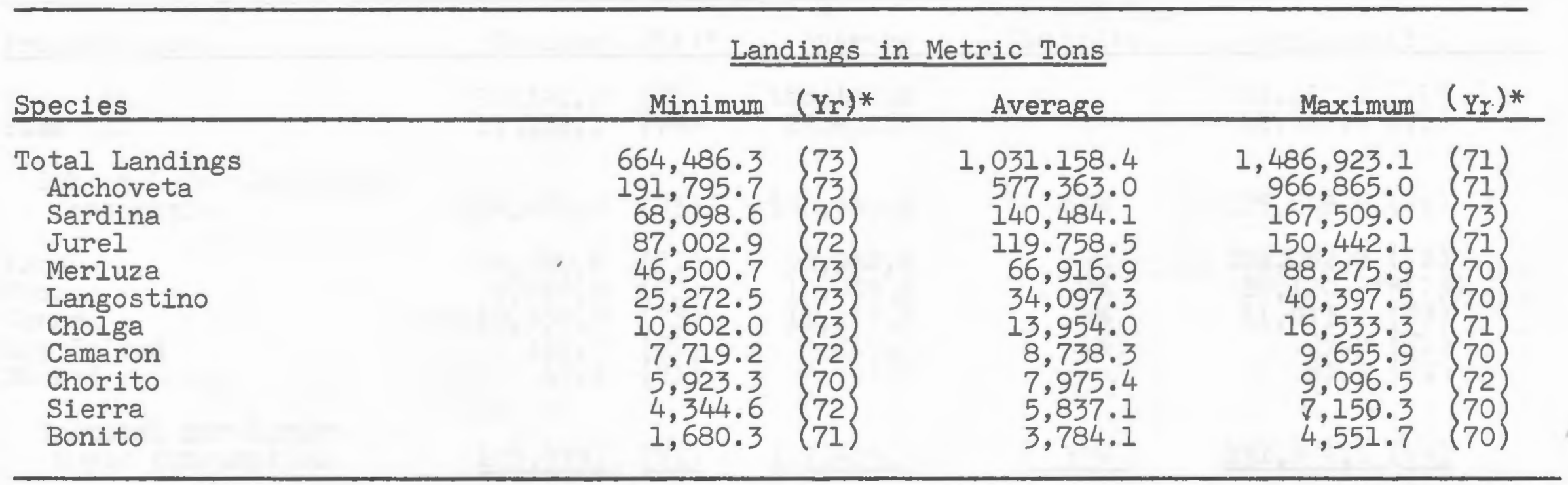

*Indicates the Year in which minimum or maximum production occurred.

Source: Anuarios y Sintesis Estadistica de Pesca S.A.G. 
IEtleE Eelecteä resesures of Crilean Fishery Procuction 1970-73

\begin{tabular}{|c|c|c|c|c|c|}
\hline Product Form & Linimum & $(Y r) *$ & Average & $\begin{array}{l}\% \text { of Total } \\
\text { Quantity }\end{array}$ & Iiaximum (Yr) \\
\hline $\begin{array}{l}\text { Fish Weal } \\
\text { Fish Oil }\end{array}$ & $\begin{array}{l}93,341,7 \\
11,132,1\end{array}$ & $\left(\begin{array}{l}73 \\
75\end{array}\right)$ & $\begin{array}{r}168,148,0 \\
23,451,8\end{array}$ & & $\begin{array}{r}263,130,8\left(\begin{array}{l}71 \\
62,517,8 \\
71\end{array}\right)\end{array}$ \\
\hline $\begin{array}{l}\text { Subtotal for Industrial } \\
\text { Consumption }\end{array}$ & $104,473,8$ & $(73)$ & $196,599,8$ & $63 \%$ & $325,648.6(71)$ \\
\hline $\begin{array}{l}\text { Fresh } \\
\text { Frozen } \\
\text { Canned } \\
\text { Dry Salted } \\
\text { Smoked }\end{array}$ & $\begin{array}{r}84,740,8 \\
5,516,9 \\
10,358,8 \\
186,7 \\
47,5\end{array}$ & 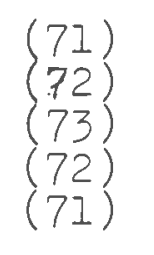 & $\begin{array}{r}96,042,8 \\
10,005,5 \\
11,113,6 \\
219,9 \\
43,7\end{array}$ & $\begin{array}{r}84 \% \\
7 \% \\
8 \% \\
1 \%\end{array}$ & $\begin{array}{r}101,082,7(72) \\
20,120.4 * *(73) \\
11,913,2(70) \\
305,2(71) \\
60,9(72)\end{array}$ \\
\hline $\begin{array}{l}\text { Subtotal for Direct } \\
\text { Human Consumption }\end{array}$ & $105,579,1$ & $(71)$ & $\underline{117,425,5}$ & $37 \%$ & $131,84,1$ (i三) \\
\hline TOTAL PRODUCTION & $206,277,9$ & $(73)$ & $314,025,3$ & $100 \%$ & $431,227,9(71)$ \\
\hline
\end{tabular}

* Indicates year in which minimum or maximum production accurred.

* This figure includes nearly 15000 IT of frozer merluza fished and processea by USSR factory slips, under a special contract.

Source: Anuario y Sintesis Estadistice de PESCA-SAC 
Figure 3 - Marketing Channels for Fresh Fishery Products

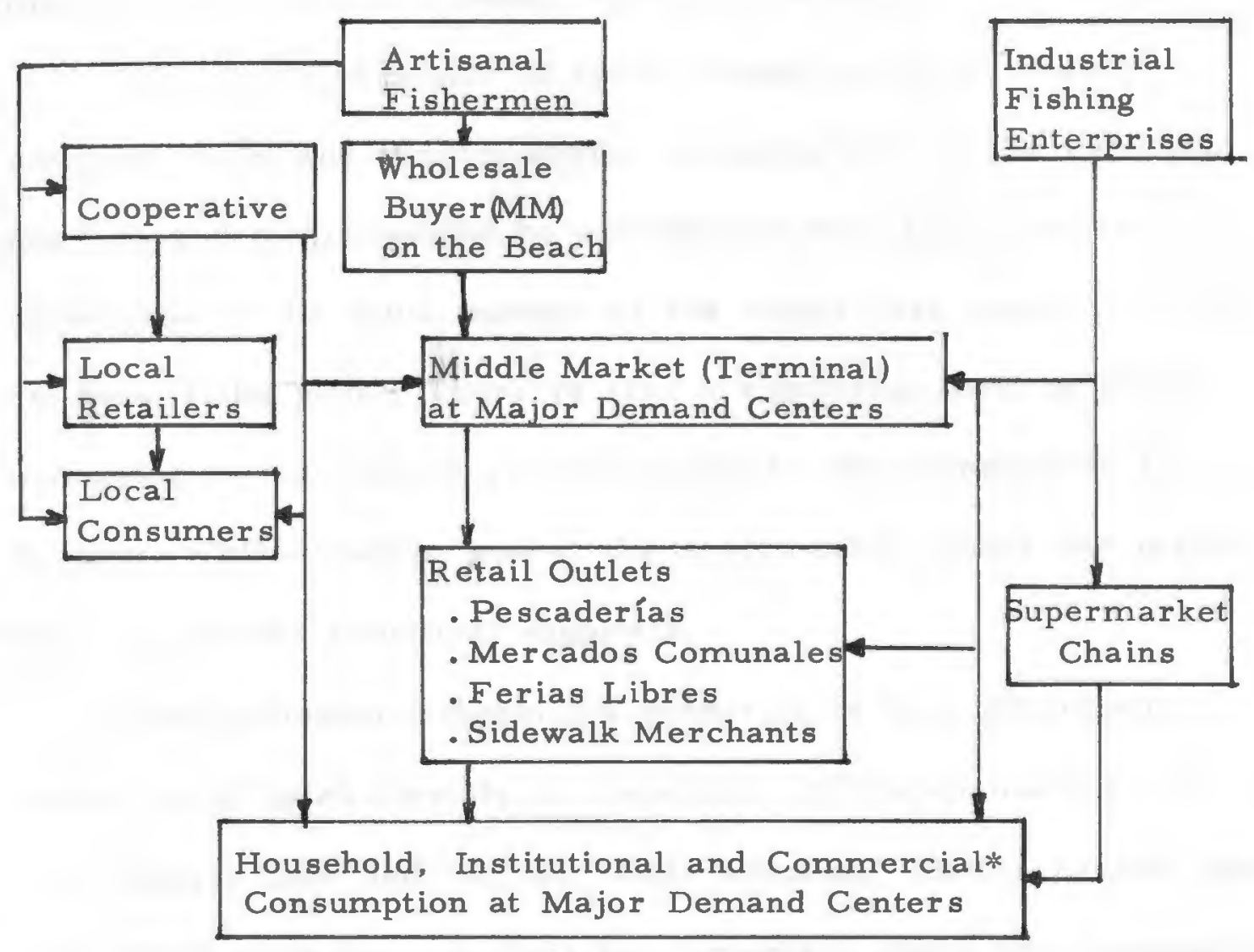

* Institutional consumption covers Industries and Commerce (non-food)hospitals, police, schools, military, etc. while commercial refers to establishments where fish is expended - restaurants, hotels, etc. 
(pescaderías) and public markets (mercados) or periodic fairs, where agricultural produce and fish are sold usually once a week (ferias) or by mobile sidewalk vendors and traders (canasteros). The industrial supply of fresh fishery products, mainly merluza, jurel and congrio negro, is partly sold at the wholesale markets and merchandised by pescaderías, mercados, ferias or canasteros in the same manner as the supply that comes from the artisanal fishermen. There is also a significant level of direct marketing to the consumer, carried out by one company so far, Pesquera Chile-Arauco, and to the supermarket chains and institutions by several industrial suppliers.

Some artisanal fishermen's cooperatives have attempted to market their catch directly to consumers in distant markets, but these efforts have had, so far, little success. Better results have been obtained by them in their local markets where the cooperatives usually provide facilities and services for the sale of the member's catch, open normally to consumers and merchants as well, e.g. Cooperativa San Antonio in San Antonio. In other cases the cooperatives have succeeded in establishing fish food outlets - - restaurants, e.g. Cooperative El Membrillo, Valparaíso, or permanent retail outlets in distant markets (Cooperativa Puertecito from San Antonio recently inaugurated an outlet in the Feria del Mar in Santiago). 
Processing and Distribution of Frozen and Canned Fishery Products

The industrial processing of fishery commodities is carried out at the nearly 95 plants that operate in the country. Marketing of the production is slightly different for frozen or canned products. Because of the need for refrigeration and the relatively high costs of frozen commodities (langostino, white fish fillets, etc.) those commodities are marketed mostly to the higher income consumers, usually through supermarket chains, or exported.

Canned fishery products, on the other hand do not require special preservation during the distribution process. For this reason the commodities are retailed not only by supermarkets but also by the more traditional stores (almacenes), as well as the corner stores in the low income areas. Current exports of Chilean canned fishery products is negligible. Marketing and Exports of Fish Meal and Oil

Approximately $80 \%$ of the Chilean production of fishmeal is exported and the rest goes into the domestic market. Most of the domestic consumers of fishmeal are either agricultural feeds manufacturers, or producers of pork or poultry who mix their own feeds. Fishmeal manufacturers usually sell either to wholesale dealers of agricultural commodities, to agricultural cooperatives, or directly to the consumers.

The marketing channels for processed fishery products are shown in Figure 4. 
Figure 4 - Marketing Channels for Processed Fishery Products

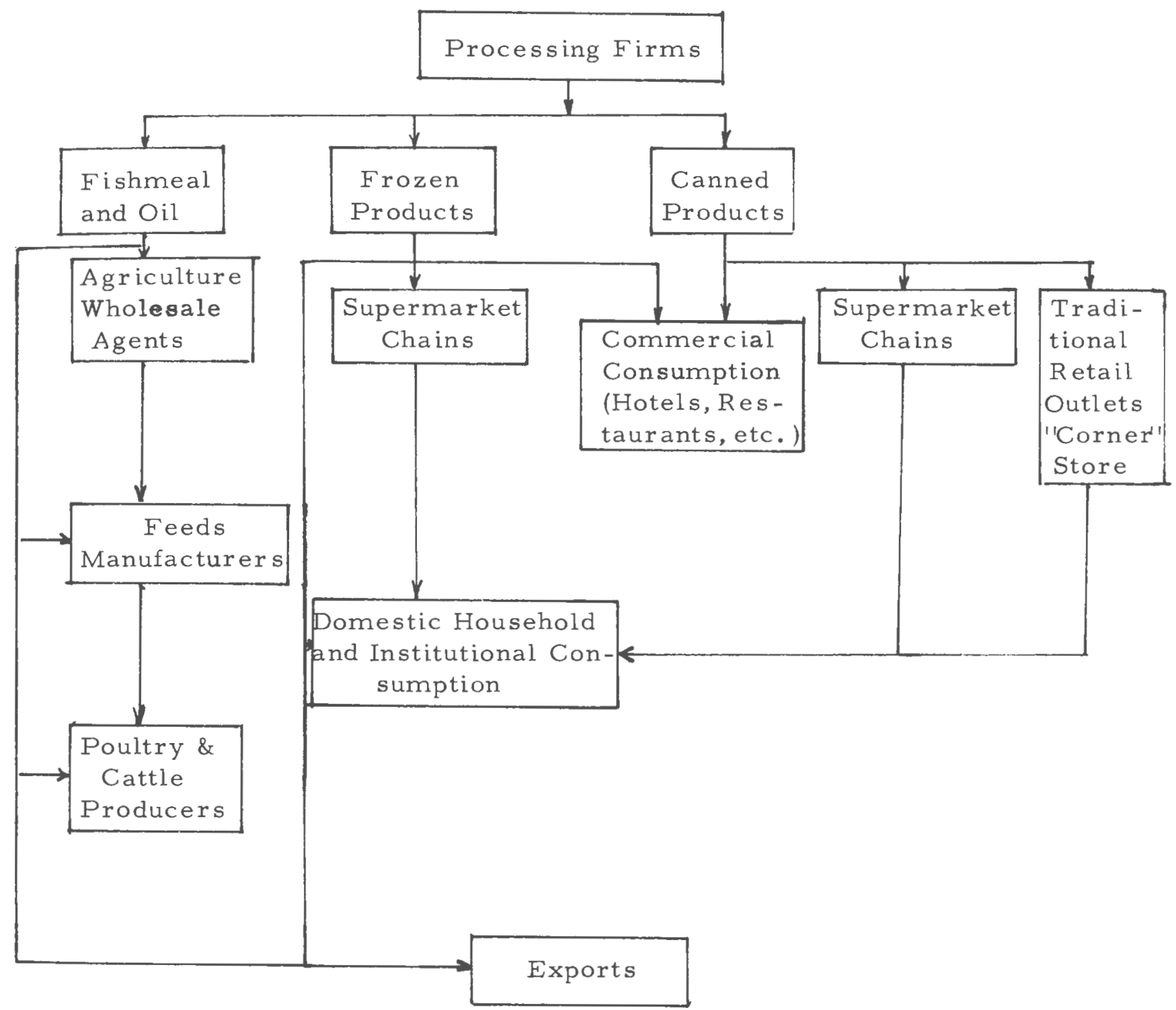


4. The Fisheries and Related Activities as an Economic System.

The fisheries and related activities can be conceptualized as a socioeconomic system formed by the following subsystems:

(a) A supply subsystem with the following components:

- Fishery resources

- Extractive activities

artisanal

industrial

- Processing activities

for intermediate goods: fish or crustacean meal and oil for final goods, in fresh, frozen, canned or other forms

(b) A demand subsystem with the following components:

- Marketing activities

wholesale

retail

- Domestic markets, the Chilean households in the different regions of the country

- Export markets, the countries that currently do, or potentially may, import Chilean fishery products

(c) A supporting activities subsystem with the following components:

Note: This subsystem will not be treated in the analysis that is performed on the subsequent chapters. 
- Resource research and management (stock assessment and fishery regulation)

- Landings and distribution infrastructure: ports, roads, public provision of distribution facilities including frozen storage

- Shipbuilding and maintenance dockyards

- Market research and information services

- Education, i. e. technical and professional development The operation of the entire system can be characterized by the interaction beween the demand for an supply of goods and services under the constraints imposed by nature (size and yield of the resource stocks) the size of the markets and the capacity of supporting activities.

The demand for fishery products and supply of labor or capital for fishing and other activities results from the utility maximizing behavior of the consumer, constrained by his endowment of resources; while the supply of fishery products and demand for labor and capital services result from the profit maximizing behaviour of the firms, constrained by the production function and availability of natural resources. The interaction between these two sets of functions yields a vector of short run equilibrium inputs (i. e. capital, labor and other inputs) and a vector of short run equilibrium outputs that in real life is reflected by the amounts of each commodity that are transacted in the market. 
Constraints on Fisheries Performance

The primary constraints that may limit the output of the fisheries is naturally the availability of fishery resources. Considering the fact that these are renewable, the size of fish populations and their reproduction rate determine the maximum sustainable yield for each species, i. e. maximum amount that can be extracted during a period (usually stated in annual terms) without decreasing the size and yield of the population for the following periods. This constraint is one that rational exploitation of the fisheries would have to adhere to in order to maximize long run yield. Within these constraints, the extractive capacity of the fleet and the landings infrastructure provide additional constraints. Given the availability of fishery resources, another set of constraints appear in the capacity to transfer and/or distribute fishery commodities. These capacities are in the short run fixed, but over long periods of time may be changed in response to shifts in the demand for these commodities. Both in the short and long run, however, the availability of other production factors may become another constraining factor.

Finally, the size of markets may constitute an additional constraint.

5. Expansion Alternatives for the Chilean Fisheries

The principal sources for the expansion of the contribution of the Chilean fisheries to the economy are: 
(a) Expansion of the extraction of natural resources from (i) currently underexploited species, (ii) currently unexploited species.

(b) Fish and shellfish cultures, and

(c) The improved utilization of fishery resources Expansion of the Catch from Natural Resources

Estimates made by IFOP place the maximum sustainable yield from fishery resources at nearly $2,000,000$ metric tons per year. A breakdown of the current and potential catch by species is given in Table 7 . It shows that the possibilities of expansion of the catch from conventional resources may come mainly from:

$$
\begin{aligned}
& \text { jurel, which could yield an additional } 110,000 \mathrm{~m} . \mathrm{t} . / \mathrm{yr} \text {. } \\
& \text { sierra (thyrsites atun - mackerel) } 20,000 \text { m.t./yr. } \\
& \text { merluza and other white fish } 84,000 \text { m.t./yr. } \\
& \text { cholgas (aulacomya ater-mussels) 243,000 m.t./yr. } \\
& \text { choritos (mytilus edulis - mussels) 17,400 m.t./yr. }
\end{aligned}
$$

The new species, yet unexploited, include:

agujilla (scombersox stolatus - saury) that could yield $105,000 \mathrm{~m} . \mathrm{t} . / \mathrm{yr}$. and merluza de cola (macruronus magellanicus) that could yield 140,000 m.t./yr. 


\begin{tabular}{|c|c|c|}
\hline Fish & $\begin{array}{l}\text { Current Average } \\
\text { Landings - } 1970-73 \\
\text { M.T. Per Year } \\
\end{array}$ & $\begin{array}{l}\text { Potential } \\
\text { Yield }\end{array}$ \\
\hline Anchoveta & $577,363,0$ & $780,000,0$ \\
\hline Sardina & $140,484,1$ & $120,000,0$ \\
\hline Jurel & $119,758,5$ & $230,000,0$ \\
\hline Merluza & $66,916,9$ & $108,500,0$ \\
\hline Bonito & $3,784,1$ & $20,000,0$ \\
\hline Sierra & $5,837,1$ & $26,000,0$ \\
\hline Agujilla & -- & $140,000,0$ \\
\hline Merluza de cola & -- & $105,000,0$ \\
\hline Other Fish & $21,630,8$ & $65,000,0$ \\
\hline TOTAL FISH & $935,775,5$ & $1,594,500,0$ \\
\hline \multicolumn{3}{|l|}{ Shellfish } \\
\hline Cholgas & $13,954,0$ & $257,390,0$ \\
\hline Choritos nat. & $7,975,4$ & $25,500,0$ \\
\hline Lang. + Camaron & $42,835,6$ & $39,600,0$ \\
\hline Other Shellfish & $30,618,8$ & $34,098,5$ \\
\hline TOTAL SHELLFISH & $95,383,8$ & $346,588,5$ \\
\hline GRAND TOTAL & $1,031,158,3$ & $1,951,088.5$ \\
\hline
\end{tabular}


In addition, by improved management of currently over -

exploited species, the anchoveta catch could increase by some 200,000 metric tons over the extraction rate during the reference 1

period, to its estimated M.S.Y. It is interesting to note, however, that preliminary results of the 1974 fishing year indicated an unexpected increase in the catch of sardines (clupea fueguensia, strangomera benticki, sardinops sagax). This may be caused by the interaction between two species (anchoveta and sardines) that feed on the same grounds or by errors in the classification of the catch over the past yen years, whereby catches of clupeoid fish may have been reported as anchoveta.

Fish and Shellfish Cultures

Estimates of the potential yield from fresh fish cultures are made at 92, 000 metric tons per year, based mostly on the possibilities afforded by the central and southern zones of the country.

During the period of reference (1970 to 1973) the anchoveta catch varied from a high of 967 thousand metric tons in 1971 to a low of 192 in 1973, apparently in response to two years of overfishing. The resulting average is some 200 thousand metric tons below the estimated sustainable yield of the resource under more rational exploitation.

2

Gabriel Dazarola, Juan Delard, Alfredo Valenzuela, 'Perspectivas de los Cultivos de Agua Dulce en Chile," in Seminario Sobre Perspectivas, pp. 175-186. 
The state of the art in this field is, however, at a very early stage and much biological research remains to be done before financial analysis of commercial undertakings can be performed, and the necessary investment is attracted.

Estimates of the potential yield from shellfish culture, (mainly mussels) are made at 81,600 metric tons per year. Research on the costs and benefits associated with this culture indicate an annual rate of return of $18.6 \%$ vis a vis the $17.3 \%$ that the exploitation of natural choritos yields. Utilization of Fishery Resources

Fishery resources may be used to feed people or animals and also to produce goods that satisfy other human needs. Among the latter, fish oil is used in the production of many non-food commodities, and other fish parts have been used to produce goods that are not food. By far the most important use for $f$ ishery resources is as food, either for direct human consumption or, via another step in the food chain, as cattle or poultry feed to produce other animal food for human consumption, or just to feed animals that render services that satisfy other human needs.

Two sets of forces dictate what the actual use of fishery

1

Luis E.González, et. al. "Perspectivas de Desarrollo de la Conquilicultura en Chile", Seminario Sobre Perspectivas, p. 152. 
resources are. On one hand, given the organic composition of each species, a fish may yield different proportions of their landed weight in different products. As an example, jurel may give around $19.8 \%$ of fishmeal and $3.5 \%$ of oil in the reduction process; $36.1 \%$ of fillet; $47.8 \%$ of minced flesh; $44 \%$ in smoked goods; $40.2 \%$ in canned goods. The organic composition also determines organoleptic characteristics (the way each product looks, smells and tastes) for the different products that can be made from each species of fish.

The other set of forces is provided by consumers' tastes and is manifested through their preferences and willingness to pay for each product.

The interaction of these forces over a long period of time results in an infrastructure for the extraction and transformation of fishery resources. This infrastructure provides a set of "capacity" constraints that limit in the short $r$ un the amounts of each product that may be produced, and cannot be expanded from one period to the next, but may be expanded by efforts that are sustained over several periods.

The suitability of some of the species under conventional exploitation for different forms of marketing is shown in Table 9.

In the case of the unexploited species it would appear that the agujilla may make a good canned product, while the merluza de cola seems to have most promise in the form of frozen minced 
Table 8 Suitability of Conventional Underexploitcd Viarine Species for Different Forms of Marketing

\begin{tabular}{|c|c|c|c|c|c|}
\hline Species & Forms: & Fresh & Frozen & Canned & Fish Med \\
\hline jurel & & Fair & Bad & Good & Good \\
\hline sierra & & Good & Fair & Good & Good \\
\hline $\begin{array}{l}\text { Merluza and } \\
\text { white fish }\end{array}$ & & Good & Good & Fair & Good \\
\hline cholgas & & Good & Fair & Good & -- \\
\hline choritos & & Good & Fair & Good & -- \\
\hline
\end{tabular}

Source: Seminario Sobre La Utilizacion de Especies Marinas Sub-Utilizadas en Chile, Universidad Catolica de Valparaiso, September 1975 
fish flesh, or as input in the production of fish protein concentrate. Improvement in the Utilization of Currently Extracted Resources

The average utilization of the Chilean fishery resources during $1970-73$ is shown in Table 9 . It can be seen from this Table that during the period observed, $99 \%$ of the anchoveta, $39 \%$ of the merluza, $93 \%$ of the sardinas and $76 \%$ of the jurel were directed to the production of fishmeal.

The average contribution to the gross value of the production during the same period of one metric ton of each of these species in the different forms that they may be marketed is shown in Table 10. The estimated average contribution to the net returns of the producer from one metric ton of product in each of the basic forms during the same period was: US\$

Fresh

Frozen

Canned

Fishmeal and Oil
110

164

$$
140
$$

50

It can be argued then that better uses can be made of the catch, even within current technological and capacity constraints.

l

This product is not considered in this study, as its production and marketing do not appear yet to be commercially feasible, unless in the context of governmental spending programs. For further details see references 3 , and 53 . 
Table 9 Utilization of Chilean Fishery Resources (\% of each species destined to each use)

\begin{tabular}{l|rrrccc}
\hline \multirow{2}{*}{ Species } & \multicolumn{7}{|c}{ U S E S } & & \\
& Fresh & Frozen & Canned & Other F.H.C. & Fich WEul & Totel \\
\hline bonito & 19.9 & -- & 78.2 & -- & 1.9 & 100 \\
merluza & 31.4 & 20.9 & .2 & 8.1 & $3 j .4$ & 100 \\
anchoveta & .1 & .1 & -- & .6 & 99.2 & 100 \\
sardina & 2.5 & -- & 4.5 & -- & 93.0 & 100 \\
jurel & 9.7 & 1.4 & 11.3 & 1.4 & 76.2 & 100 \\
sierra & 93.0 & -- & 5.0 & 2.0 & -- & 100 \\
choritos & 31.5 & -- & 68.5 & -- & -- & 100 \\
cholgas & 38.0 & -- & 49.6 & 12.4 & -- & 100 \\
camaron & 10.6 & 87.7 & 1.7 & -- & -- & 100 \\
langostino & 5.4 & 89.2 & 5.4 & -- & -- & 100 \\
\hline
\end{tabular}

Source: Anuario y Sintesis Estadistica de Pesca, SAG/IFOP 
Table 10 Fish Contribution to Product Value in Alterrative Usesl

(US\$ Per Ton of Raw Material)

\section{Rroduct Forms}

\begin{tabular}{|c|c|c|c|c|}
\hline Species & Fresh & Frozen & Canned & Fish Meal axd oil \\
\hline bonito & 420 & $115 *$ & 407 & 59 \\
\hline merluza & 250 & $150 * *$ & -- & 59 \\
\hline jurel & 150 & $40 *$ & 264 & 59 \\
\hline sierra & 500 & -- & 450 & 59 \\
\hline sardina & 250 & $40 *$ & 270 & 59 \\
\hline anchoveta & -- & $40^{*}$ & 264 & 59 \\
\hline camaron/lang. & 450 & $265 * *$ & 240 & -- \\
\hline $\begin{array}{c}\text { choritos/ } \\
\text { cholgas }\end{array}$ & 300 & -- & 68 & -- \\
\hline
\end{tabular}

$I_{\text {The stated contribution reflects only the difference }}$ in yields, and has no other cost elements included.

*Frozen round

**frozen fillets or tails 
If we take the merluza as an example, it makes excellent fresh or frozen products, both fetching returns to the producer three times greater and making a contribution to GNP almost five times greater than when used to make fishmeal. This argument can be repeated for jurel, sardina, and to a lesser degree for anchoveta. There are several explanations for the persistence of this apparent malallocation of resources. Factors that prevent the utilization of fishery resources in their "best" uses include technological as well as economic considerations. There are limits to the extent that all good raw material can be devoted to the production of food for direct human consumption for technical reasons: some of the catch is bound to become bruised during the extraction and handling operations and becomes unsuitable for direct human consumption. Most important, however, is an economic consideration: the price elasticity of demand, i. e. if output of fishery commodities is significantly increased, the impact of this expansion on price may be such that price may drop beyond the point needed for the producer to meet costs. Beyond some level of sales, then, this makes the domestic market prospects look unpromising for Chilean producers. In the exports markets, however, this is not the case as the entire potential Chilean production is not likely to affect prices. In the light of the above discussion, the Chilean fish processors have not been irrational in making their decisions. They 
would have been if they had had the option to produce and sell all of the alternative commodities. As it happens many fishmeal plants do not have alternative freezing and/or canning processing lines. More important, however, is the fact that although there is evidence of excess processing capacity ${ }^{1}$ stable exports market opportunities have existed so far only forfishmeal and oil. From the producer's point of view the market for other products (fresh, canned, frozen) has seemed to be at a saturation point in the domestic cases, and nonexistant in the case of exports.

The utilization of fishery resources is not itself a controllable variable, but rather the result from the interaction of the different components of the economic system described in Section 4 , each of them formed by numbers of variables. To change the current utilization of Chilean fishery resources changes must occur first in the variables that determine the economic system, and those changes must sustain themselves long enough to permit the adjustment of the processing and marketing infrastructure. Alternatives for Expansion

The three sources for the expansion of the Chilean fisheries discussed in the preceding subsections do not necessarily imply exclusive alternatives. They do, however, imply alternatives in

\footnotetext{
${ }^{1}$ CORFO's assessment of capacity utilization in 1971 indicated utilization rates of $34 \%, 13 \%$ and $15 \%$ for reduction, freezing and canning capacities respectively 15 . A comparison of registered capacity during 200 shifts against actual average production in 1970-73 indicates utilization rates of 50,20 and $25 \%$ for the same facilities.
} 
the measure that they require resources that are scarce, and their use in the implementation of one line of expansion will leave fewer resources left to implement the others. All of these ways to expand the contribution of the Chilean fisheries to the economy require the investment of capital resources that are scarce. With this consideration in mind the field of choice can be narrowed down assigning a lower priority to the aquaculture option. On one hand the uncertain state of the technology (biological research on productivity, disease control, etc.) in the case of fish culture, and on the other, the estimation of profitabilities that hardly are better than those associated with the extraction of natural resources for shellfish culture, do not warrant a concentration of effort in this option when there are unexploited natural resources that can be exploited at similar costs.

The other two sources of improvement, i.e. "expansion of the catch" and "improvements in the utilization of the catch" imply alternatives between themselves only to the extent that one be enhanced at the cost of not enhancing the other. The alternatives are not so much whether to expand the catch or utilize it better, as efforts to implement one would make it possible and more attractive to develop the other. The two efforts are in fact complements of each other. Steps to establish a long-term position among world suppliers of fishery commodities should consider: ${ }^{1}$ lShorter term strategies may consider temporary leasing of the fishing grounds, charging a fixed fee per ton extracted and/or the marketing of semi-processed goods, or similar arrangements. 
- development of the technical capacity to produce products, from available resources, of a quality acceptable in the exports market

- expansion of the market opportunities for these products

- expansion of the catch and production from the available resources.

The development alternatives present themselves in a different context now: which line of fishery production to invest in?

Canneries? Frozen production? or balanced combinations of canned or frozen products and fishmeal, depending on the characteristic of each species and the technological possibility of the joint production of main and by-products?

The basic alternatives which will be analyzed in the following chapters are:

Alternative 1 - Efforts are made to utilize the expanded catch with the currently available facilities, expanding the fresh market opportunities to its limit and, when necessary, fishmeal production capacity until all the expected catch can be processed. 
Alternative 2 - The fresh market is expanded as in

Alternative 1, while processing capacity for the production of fully elaborated frozen and canned fishery commodities is expanded as required to exploit currently underutilized species (jurel, sardinas) and unutilized species (agujilla, merluza de cola), and fishmeal capacity is expanded only as required to process by-products from the production of frozen and canned commodities.

The analysis of these alternatives will be carried out by focusing on the following nine fish species or group of fish species:

1. anchoveta

2. jurel - sierra

3. sardina

4. agujilla
5. other pelagic fish species

6. merluza

7. congrios

8. merluza de cola

9. other demersal fish species 
CHAPTER II

SIMULATION OF ECONOMIC PERFORMANCE :

DESCRIPTION OF THE MODEL

To evaluate the effects of changes in the economic system formed by the fisheries and related activities, a tool is needed that may permit the analysis of its performance over time. The specific objectives of this analysis are:

(a) to examine the response of the system to the relaxation of the fishery resources and processing capacity constraints,

(b) to explore the implications of the expanded output in the different markets for fishery commodities,

(c) to explore the implication of the expansion of the output fisheries commodities on employment, and

(d) to estimate the capital requirements and the economic benefits associated with the expansion of fishery production.

The analysis will focus on the eight most important fish species, i.e. anchoveta, jurel, sierra, sardina, agujilla, merluza, congrios, merluza de cola, and two composites of the remaining fish species, i. e. other pelagic fish, and other dem ersal fish.

The analytical tool proposed is a model that replicates the variability in physical extraction by generating catches that deviate 
randomly from the expected mean catch for each species, and characterizes processing and marketing behavior by the profit maximizing allocation of the fishery resources among their alternative uses. Discrete time increments are effected and changes in exogenous variables and other conditions constraining the system are made, and their effect on performance is evaluated. This Chapter is devoted to the description of the model, its underlying assumptions and the data used.

Section 1 describes the stochastic elements of the extractive activity

Section 2 , the simulation of extractive activity

Section 3, the economic elements of the processing and marketing activities

Section 4, the use of a profit maximizing separable programming model to characterize the fish marketing and processing activities, and

Section 5, the evaluation of processing and marketing activities. 
Section 1 -- The stochastic elements

One of the most complex characteristics of

fishery related activities is the presence of elements that are beyond human control and that affect the extractive activity in what appears to be a random manner. Among these elements the most important are (a) the weather, which affects the ease with which fish may be found and also the number and duration of safe fishing trips, (b) the interaction among fish populations, as well as with other forms of animal and vegetable life in the oceans, conforming a delicate balance in the ecology, the behavior of which is unpredictable once it is upset, (c) the currents with their important effect on the concentration of marine food and fish populations, (d) errors in the measure of the extraction rates and estimation of the size of fish populations. The variability in this case rises from the lack of accurate information on stock sizes and rates of extraction, thus bringing in an additional source of departure from the expected catch. There are, in sum, a number of factors that determine fish concentration and catchability that are still beyond human control. If we add to this the fact that fish are not easily seen and that fish schools are mobile, we can expect the results of the fishing activity to be highly variable. In analyzing economic activities that are generated by the availability of a raw material which is so variable it is imperative to account for this variability 
if we desire to capture to a meaningful extent the decision environment. One way to accomplish this is the generation of a variable catch that deviates randomly from its expected value.

\section{Section 2 -- Simulation of the Extractive Activity}

The procedure to follow to simulate the extractive activities includes:

- Generation of national catch for each species

- Distribution of the catch among fishery zones

Generation of the national catch - The current average rates of extraction for the principal fish species under conventional exploitation in Chile are shown in Table 11, along with their standard deviations.

If we assume normality in the distribution of the deviations around the mean catch for each species, and independence among the different fish species, we can simulate extractive activity by generating a normally distributed random variable $C(I)$, i. e. the national catch of a given species in a given year.

The first assumption, i.e., normality in the distribution of the deviations from the mean may not hold true when account is made of long run trends in the exploitation of each resource. In the short run, however, this assumption will generally hold true. 
Table 11 - Fish Catch Frequency Distribution Parameters (Metric Tons)

\begin{tabular}{|c|c|c|c|c|}
\hline Species & $\begin{array}{c}\text { Catch } \\
1968-72 \\
\end{array}$ & $\begin{array}{c}\text { Standard De } \\
\text { viation from } \\
\text { Mean Catch } \\
1968-72\end{array}$ & $\begin{array}{l}\text { Mean } \\
\text { Catch } \\
1970-73\end{array}$ & $\begin{array}{l}\text { Potential } \\
\text { Catch(MSY) } \\
\end{array}$ \\
\hline Anchoveta & 759,588 & 250,670 & 577,363 & 780,000 \\
\hline Jurel & 47,604 & 35,226 & 119,758 & 230,000 \\
\hline Sardina & 87,433 & 29,727 & 140,484 & 120,000 \\
\hline Sierra & 8,890 & 3,827 & 5,837 & 25,500 \\
\hline Agujilla* & $*$ & $*$ & $*$ & 140,000 \\
\hline Other Pelagic Fish & 25,120 & 15,825 & 17,455 & 60,150 \\
\hline Merluza & 84,054 & 25,200 & 66,917 & 108,500 \\
\hline Congrios & 3,670 & 700 & 4,019 & 10,000 \\
\hline Merluza de Cola* & $*$ & $*$ & $*$ & 105,000 \\
\hline $\begin{array}{l}\text { Other Dem ersal } \\
\text { Fish }\end{array}$ & 5,322 & 3,353 & 3,491 & 38,800 \\
\hline
\end{tabular}

Notes: (*) Species currently unexploited

Sources: Guzmán O., op. cit. 
The second assumption, i.e., independence of fish populations, may be questioned on the grounds that there are important predatorprey interactions between some species and competition for the same fishing grounds among others. Again the effect of these interactions becomes important in the long run, and is not significant in the short run.

Simulation of Zonal Catch - The zonal catch is arrived at by distributing the simulated national annual catch among five fishery zones, according initially to the proportions in which they have shared the catch of each species over the years 1968 to 1972. These shares are shown in Table 12 for the actual catch during the period indicated, along with the shares of potential catch based on the estimated concentrations of fish populations in each zone, towards which the distribution of the catch in the long run will be changed.

1 For the purposes of this analysis fishery zones $V$ and $V I$ have been merged. 
Table 12 - Catch Distribution by Zone

\begin{tabular}{|c|c|c|c|c|c|c|c|c|c|c|c|}
\hline \multirow[b]{2}{*}{ Species } & \multirow[b]{2}{*}{ Zones: } & \multicolumn{4}{|c|}{ Current (1968-1972) } & \multicolumn{6}{|c|}{ Potential } \\
\hline & & North & $\begin{array}{l}\text { C. } \\
\text { North }\end{array}$ & $\begin{array}{l}\text { Cen- } \\
\text { tral } \\
\end{array}$ & South & $\begin{array}{l}\text { Far } \\
\text { South } \\
\end{array}$ & North & $\begin{array}{l}\text { C. } \\
\text { North }\end{array}$ & $\begin{array}{l}\text { Cen- } \\
\text { tral } \\
\end{array}$ & South & $\begin{array}{l}\text { Far } \\
\text { South }\end{array}$ \\
\hline Anchoveta & & 0.95 & .01 & 0.04 & 0.0 & 0.0 & .89 & .05 & .06 & .0 & .0 \\
\hline Jurel & & .78 & .10 & .12 & 0.0 & 0.0 & .43 & .22 & .22 & .09 & .04 \\
\hline Sardina & & .06 & .02 & .92 & 0.0 & 0.0 & .08 & .08 & .84 & .00 & .00 \\
\hline Agujilla* & & .0 & .0 & .0 & .0 & .0 & .21 & .50 & .21 & .08 & .0 \\
\hline Other Pelagic Sp. & & .72 & .07 & .17 & .03 & .01 & .58 & .08 & .08 & .08 & .18 \\
\hline Merluza & & .0 & .02 & .97 & .01 & .0 & .0 & .01 & .69 & .23 & .07 \\
\hline Congrios & & .09 & .12 & .71 & .07 & .01 & .04 & .10 & .36 & .20 & .30 \\
\hline Merluza de Cola* & & .0 & .0 & .0 & .0 & .0 & .0 & .0 & .0 & .19 & .81 \\
\hline Other Demer sal Sp. & & .20 & .12 & .49 & .09 & .10 & .04 & .05 & .17 & .28 & .46 \\
\hline
\end{tabular}

* Species currently unexploited

Source: O. Guzmán, op. cit. 
The catch simulator replicates short run extraction, under conditions (mean catch, fleet mix and strength, catch distribution among fishery zones, etc.) that are given to it at the beginning of each annual period. From year to year these conditions may be changed to reflect the expected changes in the fleet, to incorporate new species and fishing grounds to the extractive process, and in general to reproduce the effect of a gradual increase in the catch of each species to eventually reach their maximum sustainable yields.

\section{Section 3 - Simulation of Processing and Distribution}

The need to simulate the behavior of the economic agents involved in the decisions that determine what use is made of the fish landings requires an analytical framework that is consistent with what, in this respect, economic theory tells us: if the processors are attempting to maximize profits, within the constraints imposed on their possibilities of choice by the production function, availability of inputs and the capacity of their installations (in the short run), they will buy inputs until the cost of the last unit equals the revenue associated with its contribution to production, and will produce commodities to the point where the cost of the last unit produced equals the revenue it generates. As there is no evidence to suggest that Chilean fish processors are not profit maximizers the assumption is made that that is, in effect, their objective. 
A relatively simply analytical tool that permits the

examination of this type of behavior is linear programming.

Its basic structure is the following for the problem under consideration.

$\operatorname{Max} Z=\sum_{i=1}^{I} \underset{i}{N R P U} *$, where $N R P U=$ net return associated with the production and sale of each unit of $Q_{i}$

Subject to $(A) *(Q) \leqslant B$

ij i j

Where

$A$ is a matrix of technological coefficients, and

$B$ is a vector of resource or capacity constraints, and $A, Q, B \geqslant 0$ for all i's and j's.

The optimal solution to this problem gives the optimal level for each activity and the imputed value of the scarce resources ( $r a w$ material, capacities), an indication of the marginal contribution to profits that could be expected from the relaxation of each of the binding constraints.

Other advantages of the use of linear programming are the fact that its stage of implementation in computers is fairly advanced and its solution algorithms provide an efficient way of handling large problems, which may include non-linear functions, separated into linear segments. This property is utilized in this application to handle the net revenue functions faced by the processors of fishery commodities. 
The background of this technique is as follows: Given a non-linear function $N R=f(Q)$, that is separable, i. e. $f(Q)=f_{1}\left(Q_{1}\right)+f_{2}\left(Q_{2}\right)+f_{3}\left(Q_{3}\right) \ldots$, that function can be represented by the summation of the products of linear coefficients, that represent either the value of the function at given values of its argument or the change in its value over a range of values of the argument, and auxiliary variables that indicate the relevant points or segments of the function, i.e. which of the separated variables are to be considered, given the functional relationship. Two methods are predominantly used to solve numerically the separable programming problem. One is based on the use of increments (delta method), and is best represented by the routine implemented in IBM'sMathematical Programming System. This uses segments that represent the change in the separated function value over specified increments in the value of its argument and, accordingly, auxiliary equations that include the functional relationships and zero-one variables that force all the segments up to the relevant one to be active and those following it to be inactive. This method requires then a constraint relating the changes in the value of the function over each segment to the corresponding change in the independent variable, an auxiliary equation formed by zero-one variables and a set of zero-one constraints for those variables. The other method is based on a polygonal approximation to the total function value and has been in use since the early sixties. 
This method is best represented by applications such as made 65

by Duloy and Norton, which separate the function into segments that represent total function values at appropriate values of its argument. The auxiliary equations in this case include a constraint that reflects the functional relationship and a constraint that forces one or a set of adjacent segments that add to one, to be active and the rest inactive. Under conditions of convexity or concavity this will require a single constraint besides the constraint that reflects the functional relationship.

The major disadvantage of linear programming lies in the rigid nature of its structure. In this case the basic structure of the model is a matrix of technological coefficients that is not expected to change over time. The remaining elements, i.e. objective function and constraints may be expected to remain reasonably constant during yearly periods. For the replication of long run operation, the elements that could change will be changed parametrically.

\section{Section 4 - Optimization of Fish Processing and Fresh Fish Marketing}

Estimation of Costs - Given the total fixed cost for a determined plant size, the fixed cost per unit (FCPU) is calculated dividing total fixed cost by the output, i. e.

$$
F C P U=\frac{T F C}{Q}
$$


The total variable cost for each process has been estimated and is approximately linear until capacity utilization is approached, when it is assumed that it increases at an exponential rate. Average variable cost (VCPU) will be constant then until nearly $90 \%$ of capacity utilization is reached. Average total cost (ATC) will then be $\quad \mathrm{ATC}=\mathrm{FCPU}+\mathrm{VCPU}$

The three cost functions mentioned are shown graphically for a typical process in Figure 5.

Estimation of Prices - A 24 months series of wholesale fresh fish market transactions and a 10 year series of canned products aggregated output and price levels were collected and analyzed to derive single equation estimates of the price of each commodity as a function of quantity and other variables. (Parametric prices are used for those fishery commodities that are currently exported, i.e., frozen products and fishmeal.)

Cannonical correlation analysis was used to establish initially the relevant relationships among the different variables. Least squares multiple regression was used subsequently to estimate the parameters of the relation between the relevant variables. A second stage estimation was added as a function of the output predicted on the first stage. The price or price relationships used are shown for all commodities in Appendix B. 
Fig. 5

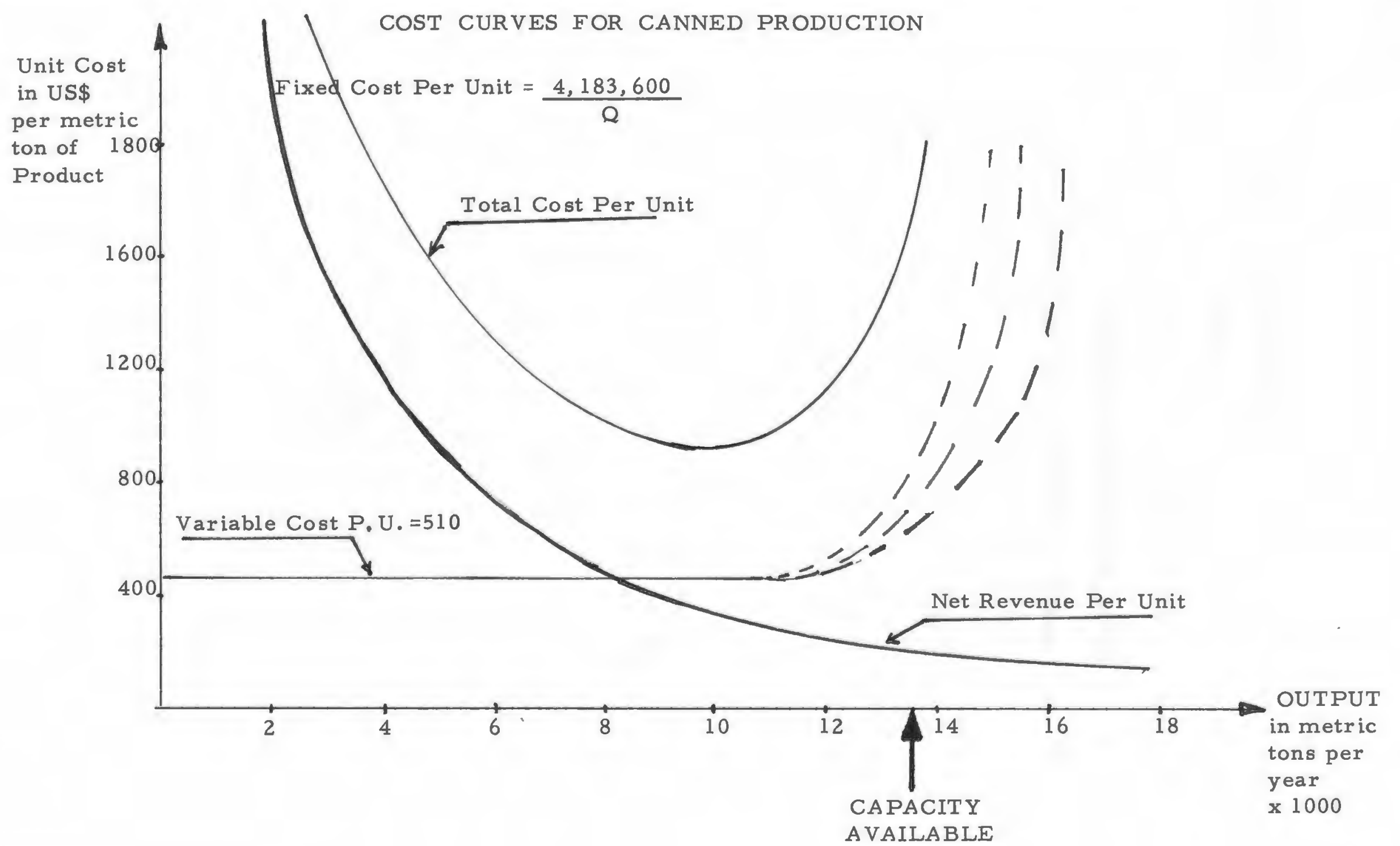


Estimation of Net Revenue Functions - The net revenue function that results from the combination of cost and demand functions has been separated into five segments for each of the commodities under consideration. The net revenue and associated output at the extreme points of each segment are listed for these commodities in Table 13. 
Table 13 - Total Net Revenue (in US\$) and Associated Outputs (in MT/yr) for Zonal Production of Selected Fishery Commoditi es

\begin{tabular}{|c|c|c|c|c|c|c|}
\hline Commodity & & Segment 1 & Segment 2 & Segment 3 & Segment 4 & Segment 5 \\
\hline Anchoveta & TNR & $-300,000$ & 900,000 & $2,000,000$ & $3,200,000$ & $2,640,000$ \\
\hline Canned & $Q$ & 4,000 & 6,000 & 8,000 & 10,000 & 12,000 \\
\hline Anchoveta & TNR & $-2,500,000$ & $7,500,000$ & $18,750,000$ & $15,000,000$ & $18,750,000$ \\
\hline Fishmeal \& Oil & $\mathrm{Q}$ & 50,000 & 100,000 & 150,000 & 200,000 & 250,000 \\
\hline Jurel & TNR & 200,000 & 600,000 & 750,000 & 600,000 & 500,000 \\
\hline Fresh & $Q$ & 10,000 & 20,000 & 30,000 & 40,000 & 50,000 \\
\hline Jurel & TNR & 115,000 & 250,000 & 360,000 & 100,000 & $-250,000$ \\
\hline Frozen & $Q$ & 5,000 & 10,000 & 15,000 & 20,000 & 25,000 \\
\hline Jurel & TNR & 60,000 & $5,400,000$ & $11,250,000$ & $12,600,000$ & 300,000 \\
\hline Canned & $\mathrm{Q}$ & 3,000 & 6,000 & 9,000 & 12,000 & 15,000 \\
\hline Jurel & TNR & 100,000 & 400,000 & 750,000 & $1,200,000$ & $1,250,000$ \\
\hline Fishmeal \& Oil & $Q$ & 10,000 & 20,000 & 30,000 & 40,000 & 60,000 \\
\hline Sardina & TNR & 10,000 & 20,000 & 30,000 & 40,000 & 50,000 \\
\hline Fresh & $Q$ & 10,000 & 20,000 & 30,000 & 40,000 & 50,000 \\
\hline Sardina & TNR & 60,000 & $5,400,000$ & $11,250,000$ & $12,600,000$ & 300,000 \\
\hline Canned & $Q$ & 3,000 & 6,000 & 9,000 & 12,000 & 15,000 \\
\hline
\end{tabular}




\section{Commodity}

Segment 1

Segment 2

Segment 3

Segment 4

Segment 5

\begin{tabular}{|c|c|c|c|c|c|c|}
\hline Sardina & TNR & 100,000 & 400,000 & 750,000 & $1,200,000$ & $1,250,000$ \\
\hline Fishmeal \& Oil & $Q$ & 10,000 & 20,000 & 30,000 & 40,000 & 50,000 \\
\hline Agujilla & TNR & 60,000 & $5,400,000$ & $11,250,000$ & $12,600,000$ & 300,000 \\
\hline Canned & $Q$ & 3,000 & 6,000 & 9,000 & 12,000 & 15,000 \\
\hline Agujilla & TNR & 100,000 & 400,000 & 750,000 & $1,200,000$ & $1,250,000$ \\
\hline Fishmeal \& Oil & $Q$ & 10,000 & 20,000 & 30,000 & 40,000 & 50,000 \\
\hline Other Pelagic & TNR & 750,000 & $1,500,000$ & $2,250,000$ & $2,400,000$ & $1,500,000$ \\
\hline Fresh & $Q$ & 3,000 & 6,000 & 9,000 & 12,000 & 15,000 \\
\hline Other Pelagic & TNR & 60,000 & 540,000 & $11,250,000$ & $12,600,000$ & 300,000 \\
\hline Canned & $Q$ & 3,000 & 6,000 & 9,000 & 12,000 & 15,000 \\
\hline Other Pelagic & TNR & 100,000 & 400,000 & 750,000 & $1,200,000$ & $1,250,000$ \\
\hline Fishmeal \& Oil & $Q$ & 10,000 & 20,000 & 30,000 & 40,000 & 50,000 \\
\hline Merluza & TNR & $1,200,000$ & $2,500,000$ & $3,000,000$ & $3,000,000$ & $2,500,000$ \\
\hline Fresh & $Q$ & 10,000 & 20,000 & 30,000 & 40,000 & 50,000 \\
\hline Merluza & TNR & $-200,000$ & 80,000 & $1,200,000$ & $2,400,000$ & $-240,000$ \\
\hline Frozen & $Q$ & 4,000 & 8,000 & 12,000 & 16,000 & 20,000 \\
\hline Merluza & TNR & 100,000 & 400,000 & 750,000 & $1,200,000$ & $1,250,000$ \\
\hline Fishmeal \& Oil & $Q$ & 10,000 & 20,000 & 30,000 & 40,000 & 50,000 \\
\hline
\end{tabular}


Table 13 (cont.)

\begin{tabular}{|c|c|c|c|c|c|c|}
\hline Commodity & & Segment 1 & Segment 2 & Segment 3 & Segment 4 & Segment 5 \\
\hline Congrio & TNR & 125,000 & 250,000 & 375,000 & 500,000 & 625,000 \\
\hline Fresh & $Q$ & 500 & 1,000 & 1,500 & 2,000 & 2,500 \\
\hline Congrio & TNR & $-2,000,000$ & 80,000 & $1,200,000$ & $2,500,000$ & $-2,400,000$ \\
\hline Frozen & $\mathrm{Q}$ & 4,000 & 8,000 & 12,000 & 16,000 & 20,000 \\
\hline Congrio & TNR & 100,000 & 400,000 & 750,000 & $1,200,000$ & $1,250,000$ \\
\hline Fishmeal \& Oil & $Q$ & 10,000 & 20,000 & 30,000 & 40,000 & 50,000 \\
\hline Merluza de Cola & TNR & $-2,000,000$ & 80,000 & $1,200,000$ & $2,500,000$ & $-2,400,000$ \\
\hline Frozen & $Q$ & 4,000 & 8,000 & 12,000 & 16,000 & 20,000 \\
\hline Merluza de Cola & TNR & 100,000 & 400,000 & 750,000 & $1,200,000$ & $1,250,000$ \\
\hline Fishmeal \& Oil & $Q$ & 10,000 & 20,000 & 30,000 & 40,000 & 50,000 \\
\hline Other Demersal & TNR & 750,000 & $1,200,000$ & $2,250,000$ & $2,500,000$ & $1,500,000$ \\
\hline Fresh & $Q$ & 3,000 & 6,000 & 9,000 & 12,000 & 15,000 \\
\hline Other Demersal & TNR & $-2,000,000$ & 80,000 & $1,200,000$ & $2,400,000$ & $-2,400,000$ \\
\hline Frozen & $Q$ & 4,000 & 8,000 & 12,000 & 16,000 & 20,000 \\
\hline Other Demersal & TNR & 100,000 & 400,000 & 750,000 & $1,200,000$ & $1,250,000$ \\
\hline Fishmeal \& Oil & $\mathrm{Q}$ & 10,000 & 20,000 & 30,000 & 40,000 & 50,000 \\
\hline
\end{tabular}


Allocation of Fish Resources - Given the catch by species, the costs associated with each process, and the demand for each fishery commodity, the net return per unit of product (NRPU) is determined for each of the $\mathrm{n}$ products. The function

$$
\sum_{i=1}^{m} \operatorname{NRPU}_{i} * \times Q_{i} \text { is formed, for } i=1 \text { to } 1
$$

to be maximized subject to the capacity constraints

$$
\sum_{i=1}^{m} Q_{i j} \leqslant B_{j}, \text { for process } j=1 \text { to } 4 \text {; }
$$

and the 9 resource constraints

$$
\sum_{j=1}^{n} \quad c_{i j} Q_{i j} \leqslant R_{i} \text { for resources } i=1 \text { to } 9 .
$$

Each $N R P U_{i} \times Q_{i}$ is separated into five linear segments that represent total revenue at each output level, in the form shown graphically in Figure 6. Constraints that represent the functional relation between output and total revenues and logical restrictions, to ensure that only one or adjacent segments that add to one are active, are also included to complete the basic structure of the model that characterizes the short run profit maximizing behavior of the fish processors and distributors in each of the country's five fishing zones. The difference in the treatment of each fishery zone is provided by the capacity and resource constraints. A list 
Fig. 6 - SEPARATION OF NET REVENUE FUNCTION -

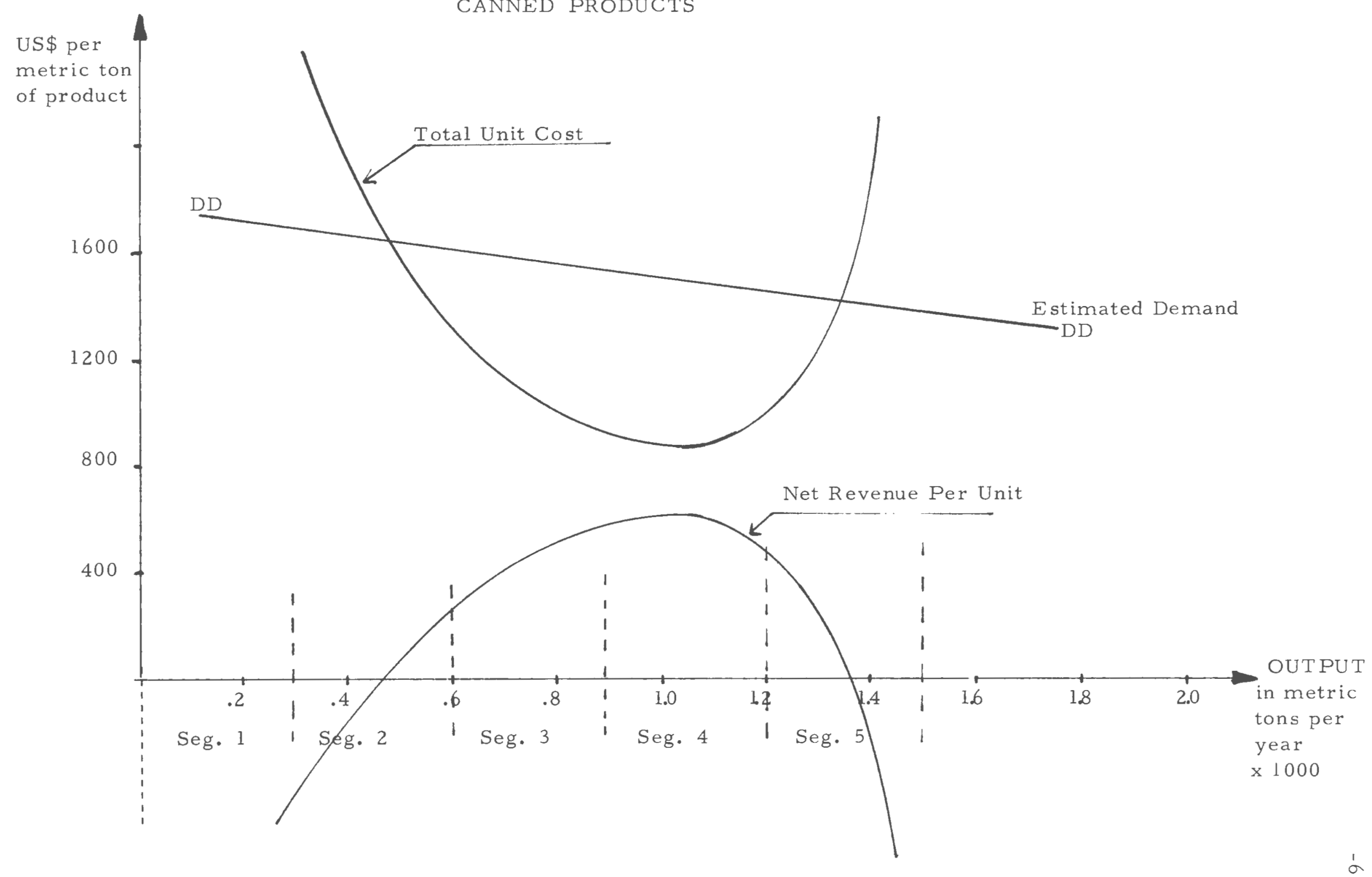


of the separable programming variables is shown on Appendix C, while the capacity constraint vectors, for each fishery zone are shown in Table 14. 
Table 14 - Current and Projected Zonal Capacities

for the Production of Fishery Commodities

(in Metric Tons ${ }^{1}$ )

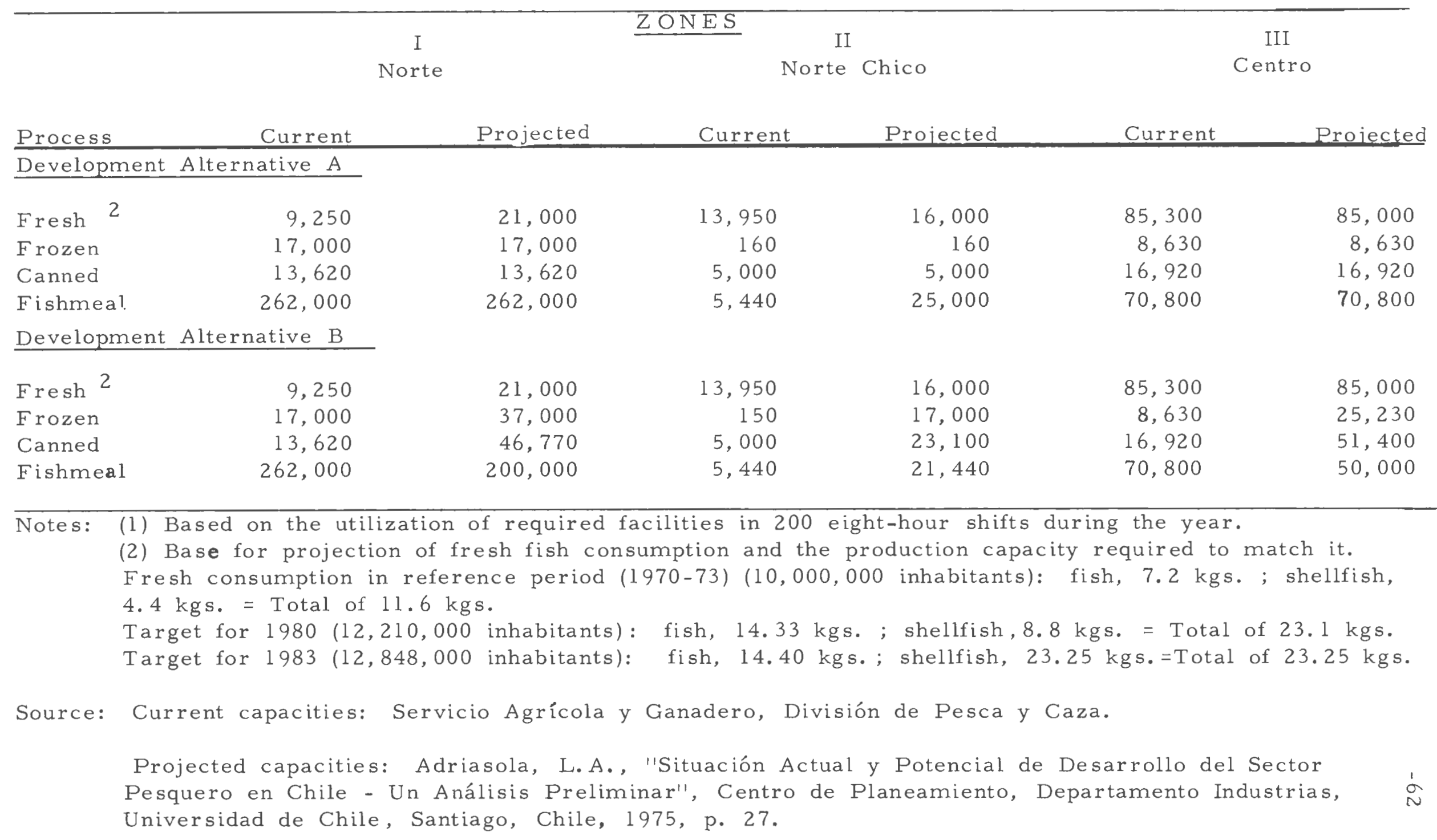




\section{ZONES}

IV

V

Sur

Austral

Nation's Total

\begin{tabular}{|c|c|c|c|c|c|c|}
\hline Process & Current & Projected & Current & Projected & Current & Projected \\
\hline \multicolumn{7}{|c|}{ Development Alternative A } \\
\hline Fresh ${ }^{2}$ & 7,500 & 35,000 & -- & 28,000 & 116,000 & 185,000 \\
\hline Frozen & 400 & 400 & - & -- & 26,190 & 26,190 \\
\hline Canned & 13,226 & 3,226 & 1,000 & 1,000 & 39,766 & 39,766 \\
\hline Fishmeal & -- & 16,300 & -- & 1,700 & 338,240 & 370,800 \\
\hline \multicolumn{7}{|c|}{ Development Alternative B } \\
\hline Fresh ${ }^{2}$ & 7,500 & 35,000 & -- & 28,000 & 116,000 & 185,000 \\
\hline Frozen & 400 & 13,720 & - - & 28,000 & 26,190 & 120,950 \\
\hline Canned & 3,226 & 5,670 & 1,000 & 2,560 & 39,776 & 129,500 \\
\hline Fishmeal & - & 15,000 & -- & 15,000 & 383,240 & 301,440 \\
\hline
\end{tabular}


Long-run Simulation - In the simulation of long run operation, different sets of NRPU's, $B_{j}^{\prime} s$ and $R_{i}{ }^{\prime} s$ may be entered as parametric changes to the model. These changes should reflect in the case of net returns per unit the interaction between supply and domestic and export demand. In the first case as production increases for a given plant size, average cost first decreases and then increases as utilization approaches capacity. For expansions of plant size, average costs shift reflecting economies of scale. In the case of demand, domestic prices change to reflect the effect on price of the increased outputs of the different commodities, and exports prices could be changed to reflect the changes in the position of Chilean fishery commodities in the world market (i.e.prices significantly lower than the competition to gain entrance, and slightly lower once a position in the market has been assured.).

In the case of $B_{j}{ }^{\prime} s$ changes, they reflect the expansion of processing capacity, and the $R_{i}{ }^{\prime} s$ the introduction of new species and changes in the shares of the catch for each zone.

Sensitivity Analysis- Different optimal solutions to the separable programming problem may result in front of changes in the input data. The principal changes that are of interest to investigate refer to the level of the constraints, and the coefficients of the objective (net revenue) function. Practically all the relevant changes in the level of the constraints are covered by the changes in the conditions considered by the situation (initial and projected) and the differences among zonal constraints. It is interesting then to test to some extent the sensitivity of overall results 
to changes in the coefficients of the objective function. Two types of changes are tested. In one case a flat $10 \%$ increase or decrease in the net revenues for all commodities is considered. The consideration of changes in relative prices is precluded by the large number of possible combinations and the scope and limited resources available for this study. A second type of change in the objective function coefficients refers to the consideration of different objective functions for the different zones. The structure of the separable programming model as stated in this section, considers a general objective function, that is applied to all of the fishery zones, and reflects the net revenues shown on Table 13 . This objective function is based on the simplifying assumption that transportation costs and demands faced by producers of fishery commodities in all zones are the same. In the actual performance of the fisheries economic system this is naturally not the case, particularly since the Chilean geography presents a contrast between the concentration of the sources of raw material and supply of fishery commodities with the concentration of the demand centers. The detailed examination of the spatial relationship between supply and demand centers is beyond the scope of this study. A partial aspect of the implications of the spatial relationship can be obtained however by incorporating transportation costs to the net revenue function, using one 
market in the central zone (Santiago) as a reference demand center. The resulting net revenue functions (objective function coefficients) are shown on Appendix D. Different objective functions result then for each zone, reflecting the impact of the cost of transporting all commodities to the reference market.

\section{Section 5 - Evaluation of Performance}

The optimal solution to the linear programming model gives for each year and each zone, the optimal outputs for each commodity, the net returns associated with them and the scarcity values for each capacity or resource that constrains production. The net returns to the producer are an adequate indicator of private performances in the production or marketing of each commodity. Aggregation of zonal results leads to yearly performance, that can be stated in relation to investment. Aggregation of yearly performance leads to long run performance that can be stated in terms of internal rates of return on investment. Social performance may be partially evaluated on the basis of output, associated net returns and contribution to employment.

A flow chart of the simulation of the operation of the Chilean fisheries and related activity is shown in Figure 7. 
Fig. 7 FLOW CHART

SIMULATION OF FISHERIES OPERATION

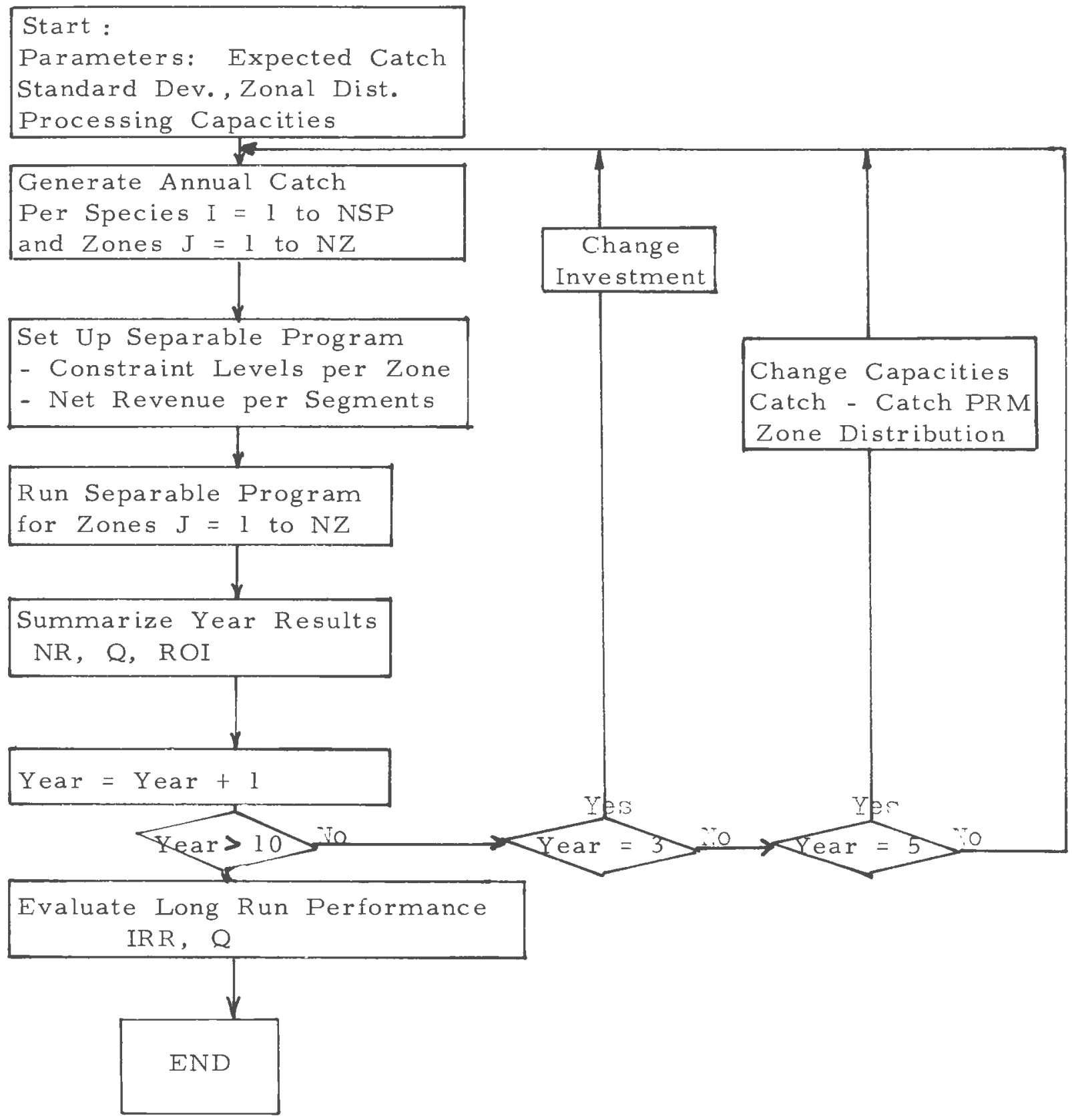




\section{CHAPTER III}

\section{SIMULATION OF ECONOMIC PERFORMANCE: RESULTS}

The objective of this chapter is to present the results of the simulated operation of the fisheries economic system under the two expansion alternatives defined in Chapter I, pages 40 and 41 . The two alternatives consider an increase in the availability of fishery resources, and differ on the adjustments done to transform the increased catch into final products. In the case of fresh production the adjustment involved is increasing the extractive capacity while in the production of processed commodities, the adjustment involved is the expansion of processing facilities. Alternative A considers solely the expansion of fresh production and fishmeal processing capacities while the current capacity for other processing methods is held constant. Alternative B considers the expansion of fresh production as well as conventional food processing capacities (canning, freezing), while fishmeal processing capacity is reduced in those zones where it is excessive.

1. Initial and Projected Conditions

The initial and projected conditions for the operation of the processing subsystem are given by

a) the current and potential expected catch, shown in Table 11, page 46, that determine the level of the resource 
constraints at a national level.

b) the current and potential zonal catch distribution shown in Table 12 , page 49 , that along with a) determine the level of the resource constraints at the zonal level.

c) the current and potential zonal processing capacities shown in Table 14, page 62 , that determine the level of the capacity constraints for each zone.

d) the net revenue function associated with the production of each commodity, shown in Table 13, page 56 , that determines the coefficients for the objective function; and

e) the investment embodied in existing facilities and that required to effect capacity increases, shown in Table 15 , page 70 , information utilized to complete the computations of returns on investment.

For both alternatives the investment required to expand capacity is made at the beginning of the third year of the simulation, and the capacity expansion is effected at the beginning of the fifth period.

\section{Short-Run Performance}

The indicators of yearly performance are
a) output and associated prices for each commodity
b) net revenues and static return on investment
c) slack available and associated shadow prices for the 
Table 15 Estimated Investment in the Production of Fishery Commodities in US\$ of $1975 \times 1000$

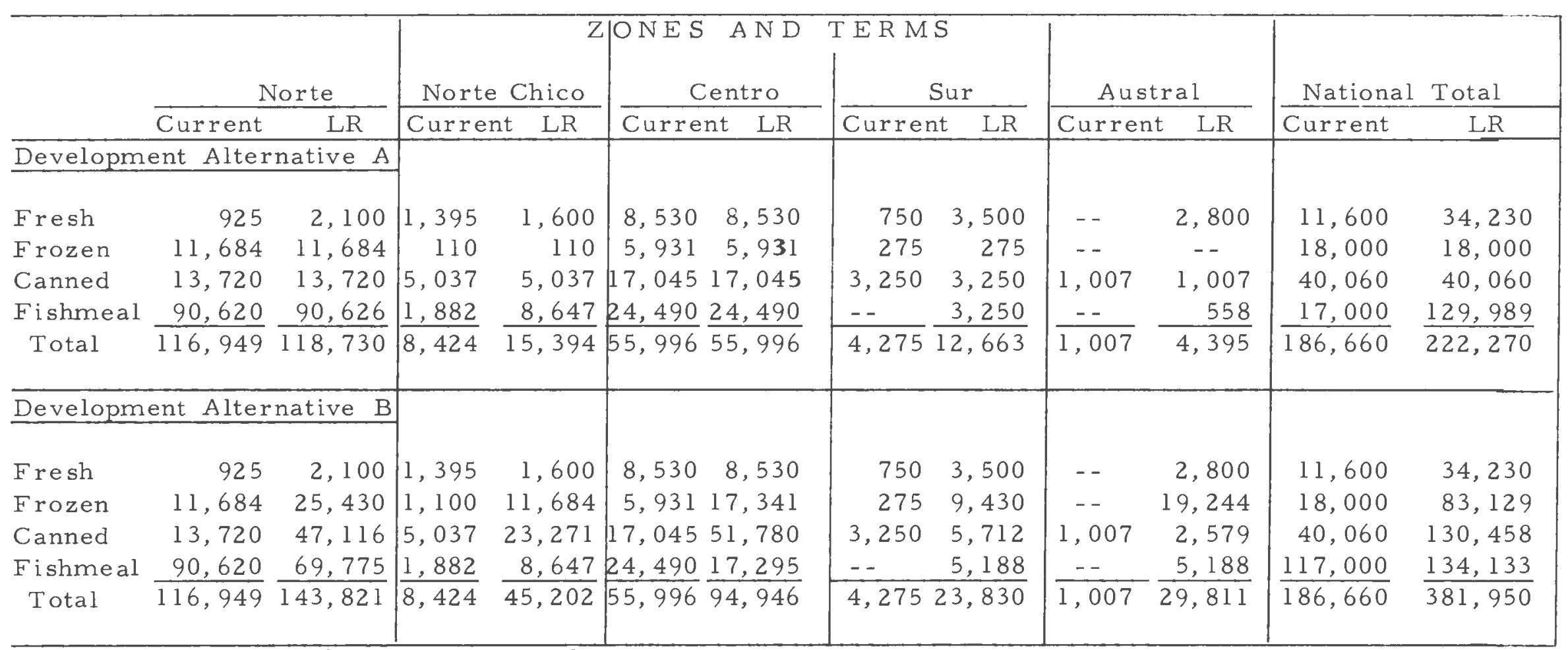

Source: IFOP, Sección Estudios Económicos for current investment in processing facilities and linear projections for expanded capacities. In the case of extraction for fresh marketing, assumed to be carried out by artisanal fishermen, an average investment of US $\$ 650$ per fisherman, and a productivity of 6.5 metric tons per year is initially assumed and projected linearly for the estimation of investment required for expanded output. 
constraints limiting production at each zone

d) employment

The optimal yearly output of each commodity is shown in Table 16 , pages 72 and 73 .

The net revenue and rate of return on investment for each zone and year are shown in Table 17, page 74 , and the slack available and shadow prices for the 13 constraints is shown for each zone and selected periods in Table 18, page 75. 
Table 16 - Separable Programming Results

Summary of Annual Outputs by Commodity (MT/yr.)

Alternative A.

Commodity

\begin{tabular}{|c|c|c|c|c|c|c|c|c|c|c|}
\hline & & f & 1 & & & & 10 & $\mathrm{r}$ & Yr. & $\mathrm{Yr}$ \\
\hline $\begin{array}{l}\text { 1. Canned Anch } \\
\text { 2. Anch FM }\end{array}$ & $\begin{array}{c}0 \\
85,000 \\
\end{array}$ & $\begin{array}{r}4,712 \\
156,100 \\
\end{array}$ & $\begin{array}{r}640 \\
62,890 \\
\end{array}$ & $\begin{array}{c}0 \\
124,800 \\
\end{array}$ & $\begin{array}{c}0 \\
172,300\end{array}$ & $\begin{array}{c}0 \\
97,180 \\
\end{array}$ & $\begin{array}{c}0 \\
110,800 \\
\end{array}$ & $\begin{array}{c}0 \\
171,300 \\
\end{array}$ & $\begin{array}{c}0 \\
173,000 \\
\end{array}$ & $\begin{array}{c}0 \\
173,000\end{array}$ \\
\hline 3. Fresh Jur.S & 0 & 0 & 0 & 2,030 & 76,910 & 86,940 & 73,520 & 80,000 & 79,440 & 69,270 \\
\hline 4. Frozen Jur. S & 0 & 15,000 & 0 & 0 & 15,000 & 0 & 0 & 15,000 & 15,000 & 15,000 \\
\hline 5. Canned J.S. & 12,690 & 6,925 & 13,920 & 18,200 & 24,260 & 26,310 & 24,500 & 24,000 & 24,500 & 21,580 \\
\hline 6.Jr.S.FM & 0 & 0 & 0 & 0 & 2,191 & 0 & 0 & 2,037 & 1,467 & 754 \\
\hline 7. Fresh Sard & 10,000 & 10,000 & 10,000 & 10,000 & 10,000 & 10,000 & 10,000 & 10,000 & 10,000 & 10,000 \\
\hline 8. Canned Sard & 17,410 & 15,970 & 14,550 & 14,300 & 7,920 & 9,822 & 12,420 & 7,920 & 7,920 & 1,341 \\
\hline 9. Sard FM & 25,380 & 11,420 & 9,205 & 17,320 & 18,710 & 3,746 & 14,760 & 17,070 & 10,940 & 5,667 \\
\hline 10. Canned Agu & 0 & 0 & 0 & 0 & 7,583 & 3,633 & 2,848 & 7,816 & 7,343 & 16,850 \\
\hline 11. Agu FM & 0 & 0 & 0 & 0 & 16,760 & 31,820 & 11,540 & 18,720 & 19,650 & 13,250 \\
\hline 12. OPF Fresh & 9,003 & 7,373 & 9,000 & 11,360 & 41,480 & 23,650 & 39,520 & 25,880 & 36,590 & 43,420 \\
\hline 13. OPF Canned & 6,346 & 8,384 & 7,157 & 3,555 & 0 & 0 & 0 & 0 & 0 & 0 \\
\hline 14. OPF Fishmeal & 6,431 & 0 & 3,775 & 2,513 & 6,033 & 785 & 5,000 & 1,379 & 4,221 & 7,209 \\
\hline 15. Fresh Merluza. & 49 & 174 & 53 & 0 & 0 & 2,075 & 1,385 & 79 & 2,514 & 1,009 \\
\hline 16. Frozen Merluza & 9,111 & 9,010 & 8,941 & 9,190 & 8,790 & 8,790 & 8,790 & 8,790 & 8,790 & 8,790 \\
\hline 17. MZA FM & 11,490 & 6,517 & 3,089 & 19,660 & 202,300 & 12,120 & 13,830 & 18,370 & 15,960 & 19,990 \\
\hline 18. Fresh Cong & 3,432 & 3,554 & 3,433 & 3,093 & 5,602 & 8,645 & 8,289 & 7,085 & 8,871 & 8,096 \\
\hline 19. Frozen Cong & 32 & 0 & 32 & 15 & 0 & 0 & 0 & 0 & 0 & 0 \\
\hline 20. Cong. FM & 0 & 0 & 0 & 0 & 0 & 0 & 0 & 0 & 0 & 0 \\
\hline 21.Frozen MdeC & 0 & 0 & 0 & 0 & 400 & 400 & 400 & 400 & 400 & 400 \\
\hline 22. MDeC FM & 0 & 0 & 0 & 0 & 4,695 & 3,799 & 4,059 & 5,245 & 4,641 & 3,184 \\
\hline 23. ODF Fresh & 879 & 1,186 & 2,576 & 927 & 16,690 & 17,510 & 14,460 & 11,080 & 13,700 & 18,610 \\
\hline 24. ODF Frozen & 251 & 0 & 736 & 965 & 0 & 0 & 0 & 0 & 0 & 0 \\
\hline $\begin{array}{l}\text { 25. ODF Fishmeal } \\
\text { SubIotals }\end{array}$ & 0 & 0 & 0 & 0 & 0 & 0 & 0 & 0 & 0 & 0 \\
\hline Eresh & 23,363 & 22,287 & 25,062 & 27,410 & 150,682 & 148,820 & 147,174 & 134,124 & 151,115 & 150,43 \\
\hline Frozen & 9,394 & 24,010 & 9,709 & 10,170 & 15,400 & 9,190 & 9,190 & 24,190 & 24,190 & 24,190 \\
\hline $\begin{array}{l}\text { Canned } \\
\text { Eisnmeal }\end{array}$ & $\begin{array}{r}36,446 \\
128,301\end{array}$ & $\begin{array}{r}35,991 \\
174,037\end{array}$ & $\begin{array}{l}36,267 \\
79,049\end{array}$ & $\begin{array}{r}36,055 \\
164,293\end{array}$ & $\begin{array}{r}39,763 \\
240,989\end{array}$ & $\begin{array}{r}39,765 \\
149,450\end{array}$ & $\begin{array}{r}36,920 \\
159,979\end{array}$ & $\begin{array}{r}39,766 \\
234,111\end{array}$ & $\begin{array}{r}39,763 \\
229,979\end{array}$ & $\begin{array}{rl}39 & 77 \\
223,281 & \end{array}$ \\
\hline
\end{tabular}


Table 16- Separable Programming Results

Summary of Annual Outputs by Commodity (MT/yr.)

Alternative $B$.

Commodity

\begin{tabular}{|c|c|c|c|c|c|c|c|c|c|c|}
\hline $\begin{array}{l}\text { 1. Canned Anch } \\
\text { 2. Anch FM }\end{array}$ & $\begin{array}{l}20,540 \\
83.870 \\
\end{array}$ & $\begin{array}{r}7,712 \\
154,400 \\
\end{array}$ & $\begin{array}{r}2,786 \\
61,800 \\
\end{array}$ & $\begin{array}{r}256 \\
124.700 \\
\end{array}$ & $\begin{array}{r}18,530 \\
166,800 \\
\end{array}$ & $\begin{array}{l}20,000 \\
86,160 \\
\end{array}$ & $\begin{array}{l}20,000 \\
99,770 \\
\end{array}$ & $\begin{array}{r}20,000 \\
165.800 \\
\end{array}$ & $\begin{array}{r}20,000 \\
167,400 \\
\end{array}$ & $\begin{array}{r}20,000 \\
167.500 \\
\end{array}$ \\
\hline 3. Fresh Jr.S. & 0 & 0 & 0 & 2,030 & 71,920 & 97,260 & 60,920 & 80,090 & 82,380 & 58,000 \\
\hline 4. Frozen Jr.S. & 0 & 12,000 & 0 & 0 & 15,000 & 0 & 0 & 15,000 & 15,000 & 15,000 \\
\hline 5. Canned J.S. & 12,690 & 6,925 & 13,920 & 18,200 & 36,760 & 40,210 & 38,630 & 36,760 & 36,610 & 36,990 \\
\hline 6. Jr. S.FM. & 0 & 0 & 0 & 0 & 0 & 0 & 0 & 0 & 0 & 0 \\
\hline 7.Fresh Sard & 10,000 & 10,000 & 10,000 & 10,000 & 10,000 & 10,000 & 10,000 & 10,000 & 10,000 & 10,000 \\
\hline 8. Canned Sard & 15,360 & 12,970 & 12,400 & 14,050 & 19,340 & 12,800 & 17,740 & 18,746 & 16,020 & 12,610 \\
\hline 9. Sard EM & 26,180 & 12.590 & $10,0 \pm 0$ & 17.420 & 16.300 & 2,584 & 12,680 & 14.746 & 9,155 & 2,178 \\
\hline 10. Canned Agu & 0 & 0 & 0 & 0 & 31,050 & 30,360 & 25,230 & 31,470 & 31,620 & 31,070 \\
\hline 11. Agu.FM & 0 & 0 & 0 & 0 & 7,615 & 21,400 & 28.170 & 9,509 & 10,190 & 7.707 \\
\hline 12.OPF Fresh & 9,003 & 7,373 & 9,000 & 11,360 & 34,710 & 7.210 & $29: 380$ & $10,6 \div 0$ & 24,760 & 30,470 \\
\hline T3.OPF Canned & 6,346 & 8,384 & 7,157 & 3,555 & 14,670 & 7,893 & 13,900 & 8,618 & 12,990 & 17,960 \\
\hline 14.OPF Fishmeal & 6.431 & 0 & 3,775 & 2,513 & 0 & 0 & 0 & 0 & 0 & . 716 \\
\hline 15. FreshMerIuza & 49 & 174 & 53 & 0 & 0 & 2,075 & 1,385 & 79 & 2,514 & 1,009 \\
\hline 16. Frozen Meriuza & 9,111 & 9,010 & 8,941 & 9,190 & 21,560 & 23,820 & 23,150 & 20,120 & 21,660 & 25,350 \\
\hline 17. MZA FM & 11,490 & 6,517 & 3,089 & 19,660 & 14,100 & 4,600 & 6,653 & 12,700 & 9,524 & 18,250 \\
\hline 18. FreshCong & 3,432 & 3,554 & 3,433 & 3,093 & 5,602 & 8,645 & 8,289 & 7,085 & 8.871 & 8,096 \\
\hline 19. Frozen Cong & 32 & 0 & 32 & 15 & 0 & 0 & 0 & 0 & 0 & 0 \\
\hline 20. Cong FM & 0 & 0 & 0 & 0 & $\underline{0}$ & 0 & 0 & 0 & 0 & 0 \\
\hline 21. Frozen MdeC. & 0 & 0 & 0 & 0 & 28,140 & 24,540 & 25,490 & 29,250 & 27,310 & 24,360 \\
\hline 22.MdeC FM & 0 & 0 & 0 & 0 & 14,300 & 8,160 & 9,779 & 15,000 & 12,890 & 7,857 \\
\hline 23. ODF Fresh & 879 & 1,186 & 2,576 & 927 & 16,690 & 17,510 & 14,460 & 11,080 & 13,700 & $18,6 \div 0$ \\
\hline 24. ODF Frozen & 251 & 0 & 736 & 265 & 0 & 0 & 0 & 0 & 0 & 0 \\
\hline 25. ODF Fishmeal & 0 & 0 & 0 & 0 & 0 & 0 & 0 & 0 & 0 & 0 \\
\hline $\begin{array}{l}\text { Subtotals } \\
\text { Eresh }\end{array}$ & 23,363 & 22,287 & 85,062 & $27,41 q$ & 138,922 & 142,700 & 124,434 & 118,974 & 142,225 & 126,21 \\
\hline $\begin{array}{l}\text { Frozen } \\
\text { Canned }\end{array}$ & $\begin{array}{r}9,394 \\
36,450\end{array}$ & $\begin{array}{l}24,010 \\
35,991\end{array}$ & $\begin{array}{r}9,671 \\
36,263\end{array}$ & $\begin{array}{r}9,470 \\
36,061\end{array}$ & $\begin{array}{r}64,700 \\
120,350\end{array}$ & $\begin{array}{r}48,360 \\
111,263\end{array}$ & $\begin{array}{r}48,640 \\
115,500\end{array}$ & $\begin{array}{r}64,370 \\
115,594\end{array}$ & $\begin{array}{r}63,970 \\
117,240\end{array}$ & $\begin{array}{r}64,71 \\
118,63\end{array}$ \\
\hline$F i \leq h$ & 127,971 & 173,507 & & $16 \div .29,3$ & 219.115 & 122.904 & 157,052 & 217,749 & 209,159 & 198,20 \\
\hline
\end{tabular}


Table 17 - Separable Programming Results: Net Revenues in US\$ x $10^{3}$ and Return on Investment $\%$ by Zone and Year

Internal Rate of Return by Zone

\begin{tabular}{|c|c|c|c|c|c|c|c|c|c|c|c|}
\hline \multirow{3}{*}{ Alternative } & \multicolumn{2}{|c|}{ ZONE I } & \multicolumn{2}{|c|}{ ZONE II } & \multicolumn{2}{|c|}{ ZONE III } & \multicolumn{2}{|c|}{ ZONE IV } & \multicolumn{2}{|c|}{ ZONE V } & \multirow{2}{*}{$\frac{\text { NATIONAL }}{\text { NR }}$} \\
\hline & A NR & $\mathrm{RO}$ & NR & $\mathrm{RO}$ & NR & $\mathrm{RO} 1$ & $\mathrm{NR}$ & ROl & NR & $\mathrm{ROl}$ & \\
\hline & 30,000 & 25 & 6,500 & 47 & 23,000 & 26 & 990 & 14 & 280 & 28 & 60,680 \\
\hline \multirow{9}{*}{$\overline{\text { Year }}$} & 38,000 & 32 & 4,100 & 29 & 20,000 & 22 & 550 & 8 & 140 & 14 & 63,110 \\
\hline & 27,000 & 21 & 5,900 & 27 & 23,000 & 25 & 850 & 3 & 230 & 2 & 56,690 \\
\hline & 34,000 & 27 & 7,200 & 33 & 25,000 & 26 & 630 & 2 & 160 & 1 & 67,080 \\
\hline & 39,999 & 31 & 10,000 & 46 & 28,000 & 32 & 8,000 & 30 & 6,200 & 40 & 91,990 \\
\hline & 31,000 & 24 & 8,800 & 40 & 27,000 & 30 & 7,400 & 28 & 5,000 & 36 & 79,380 \\
\hline & 32,000 & 26 & 9,200 & 42 & 28,000 & 31 & 7,700 & 29 & 6,200 & 40 & 83,150 \\
\hline & 39,000 & 31 & 9,200 & 421 & 27,000 & 31 & 6,800 & 26 & 4,800 & 31 & 87,480 \\
\hline & 39,000 & 31 & 9,900 & 45 & 28,000 & 31 & 7,700 & 29 & 6,200 & 40 & 91,240 \\
\hline & 39,000 & 31 & 10,000 & 47 & 29,000 & 32 & 8,300 & 31 & 6,600 & 43 & 93,080 \\
\hline
\end{tabular}

IR R

$34 \%$

$59 \%$

$24 \%$

$15 \%$

23,000
20,000
22,000
25,000
47,000
44,000
43,000
45,000
47,000
47,000

25

22

22
16

16

27,000

34,000

68,000

48,000

56,000

62,000

65,000

64,000

$33 \%$

$50 \%$

$30 \%$

990
550
850
6,300
13,000
12,000
12,000
12,000
13,000
13,000

$18 \%$

IRR

14
8
2
2
34
32
33
31
33
35

$23 \%$

Notes: (*) Sums may not check due to rounding errors. 


\begin{tabular}{|c|c|c|c|c|c|c|c|c|c|c|c|c|c|c|c|c|c|c|c|c|}
\hline \multirow[b]{3}{*}{ Constraint } & \multicolumn{4}{|c|}{ ZONE I. } & \multicolumn{4}{|c|}{ ZONE $\|$} & \multicolumn{4}{|c|}{ ZONE III } & \multicolumn{3}{|c|}{ ZONEIV } & \multicolumn{5}{|c|}{ ZONE } \\
\hline & \multicolumn{2}{|c|}{ Initial } & \multirow{2}{*}{\multicolumn{2}{|c|}{$\begin{array}{c}\text { Final } \\
\text { Slack ShP }\end{array}$}} & \multicolumn{2}{|c|}{ Initial } & \multicolumn{2}{|c|}{ Final } & \multicolumn{2}{|c|}{ Initial } & \multicolumn{2}{|c|}{ Final } & \multicolumn{2}{|c|}{ Initial } & \multicolumn{2}{|l|}{ Final } & \multicolumn{2}{|c|}{ Initial } & \multicolumn{2}{|c|}{ Final } \\
\hline & Slack & ShP & & & Slack & ShP & Slack & ShP & Slack & ShP & Slack & ShP & Slack & ShP & Slack & ShP S & Slack & $k$ ShP & Slack & ShP \\
\hline A. Mifenctive A & & & & & & & & & & & & & & & & & & & & \\
\hline 1. Fresh Capacity & 0 & 0.18 & 0 & 0.03 & 3,000 & 0 & 0 & .03 & 7,200 & 0.0 & 32,000 & 0.0 & 7,100 & 0.0 & 2,500 & 0.0 & 0 & .25 & 0 & .03 \\
\hline 2. Frozen & 17,000 & 0 & 2,000 & 0 & 0 & .13 & 0 & .13 & 0 & .13 & 0 & 0.13 & 79 & 0.0 & 0 & 0.14 & 0 & .15 & 0 & .15 \\
\hline 3. Carning & 0 & 1.2 & 0 & 1.2 & 0 & .60 & 0 & 1.2 & 0 & .44 & 0 & 1.2 & 2,500 & 0.0 & 0 & 1.2 & 770 & .0 & 0 & 1.2 \\
\hline 4. Fishmeal & 170,000 & 0.0 & 100,000 & 0.0 & 4,300 & 0.0 & 3,700 & 0.0 & 31,000 & 0.0 & 0 & 0.0 & 0 & 0.0 & 7,100 & 0.0 & 0 & .03 & 0 & .03 \\
\hline 5. Anchoveta Av & 0 & 0.0 & 160,000 & 0.0 & 0 & .03 & 0 & .03 & 0 & .03 & 0 & 0.03 & 0 & .12 & 0 & .026 & 0 & .12 & 0 & .02 \\
\hline 6. Jurel & 10,000 . & 0.0 & 60,000 & 0.0 & 0 & .26 & 26,000 & 0.00 & 0 & .005 & 0 & 0.005 & 0 & .50 & 0 & 0.03 & 0 & .50 & 0 & .00 \\
\hline 7. Sardina & 0 & 0.005 & 0 & 0.005 & 0 & .28 & 0 & .005 & 0 & .005 & 0 & 0.005 & 0 & .54 & 0 & 0.01 & 0 & .54 & 0 & .002 \\
\hline 8. Aguilila & 0 & 0.005 & 0 & 0.005 & 0 & .28 & 0 & .005 & 0 & .35 & 0 & 0.005 & 0 & .54 & 0 & 0.005 & 0 & .54 & 0 & .00 \\
\hline 9. OP Fish & 0 & 0.006 & 0 & 0.006 & 0 & .25 & 0 & .22 & 0 & .31 & 0 & 0.25 & 0 & .48 & 0 & 0.25 & 0 & .48 & 0 & .00 \\
\hline 10. Merluza & 0 & 0.06 & 0 & 0.06 & 0 & .06 & 0 & .006 & 0 & .006 & 0 & 0.006 & 0 & .06 & 0 & 0.006 & 0 & .00 & 2,700 & .00 \\
\hline 11. Congrio & 0 & 0.06 & 0 & 0.22 & 0 & .25 & 0 & .22 & 0 & .32 & 0 & 0.12 & 0 & .25 & 0 & 0.25 & 36 & .00 & 0 & .095 \\
\hline 12. Merluza de Cola & 0 & 0.07 & 0 & 0.07 & 0 & .007 & 0 & .007 & 0 & .007 & 0 & 0.007 & 0 & .07 & 0 & 0.006 & 0 & .00 & 7,100 & .00 \\
\hline 13. OD Fish & 0 & 0.06 & 0 & 0.09 & 0 & .10 & 0 & .09 & 0 & .10 & 0 & 0.10 & 0 & .10 & 0 & 0.10 & 0 & .00 & 0 & .088 \\
\hline \multicolumn{21}{|l|}{ B. Alternative B } \\
\hline 1. Fresh Capacity & 0 & 0.18 & 0 & 0.03 & 13,000 & .00 & 0 & .03 & 72,000 & 0.0 & 52,500 & 0.00 & $\$, 100$ & .00 & 6,500 & 0.0 & 0 & .25 & 180 & .00 \\
\hline 2. Frozen & 17,000 & 0.00 & 22,000 & 0.00 & 10 & .13 & 17,000 & .00 & 0 & .13 & 9,200 & 0.00 & 79 & .00 & 0 & 0.13 & 0 & .15 & 8,500 & .00 \\
\hline 3. Canning & 0 & 1.20 & 2,000 & 0.00 & 0 & .60 & 0 & .45 & 0 & .25 & 12,000 & 0.00 & 2,500 & .00 & 0 & 0.12 & 770 & .00 & 0 & 1.20 \\
\hline 4. Fishmeal & 170,000 & 0.00 & 110,000 & 0.00 & 4,300 & .00 & 4,600 & .00 & 31,000 & 0.00 & 5,200 & 0.00 & 0 & .00 & 12,000 & 0.00 & 0 & .03 & 7,100 & .00 \\
\hline 5. Anchoveta Av & 0 & 0.03 & 130,000 & 0.00 & 0 & .03 & 0 & .03 & 0 & 0.026 & 0 & 0.03 & 0 & .12 & 0 & 0.03 & 0 & .12 & 0 & .03 \\
\hline 6. Jurel & 10,000 & 0.00 & 53,000 & 0.00 & 0 & .26 & 7,800 & .00 & 0 & 0.40 & 0 & 0.03 & 0 & .50 & 0 & 0.03 & 0 & .50 & 0 & .03 \\
\hline 7. Sardino & 0 & 0.005 & 0 & 0.54 & 0 & .28 & 0 & .35 & 0 & 0.05 & 0 & 0.05 & 0 & .54 & 0 & 0.03 & 0 & .54 & 0 & .03 \\
\hline 8. Aģujilla & 0 & 0.005 & 0 & 0.005 & 0 & .28 & 0 & .005 & 0 & 0.43 & 0 & 0.005 & 0 & .54 & 0 & 0.03 & 0 & .54 & 0 & .03 \\
\hline 9. OP Fish & 0 & 0.006 & 0 & 0.005 & 0 & .25 & 0 & .31 & 0 & 0.38 & 0 & 0.48 & 0 & .25 & 0 & 0.25 & 0 & .48 & 0 & .03 \\
\hline 10. Merluza & 0 & 0.06 & 0 & 0.06 & 0 & .006 & 0 & .06 & 0 & 0.006 & 0 & .006 & 0 & .06 & 0 & 0.006 & 0 & .00 & 0 & .06 \\
\hline 11. Congrio & 0 & 0.06 & 0 & .22 & 0 & .25 & 0 & .22 & 0 & 0.12 & 0 & .12 & 0 & .25 & 0 & 0.25 & 36 & .00 & 0 & .12 \\
\hline 12. Merluza de Cola & 0 & 0.07 & 0 & .07 & 0 & .007 & 0 & .07 & 0 & 0.007 & 0 & .075 & 0 & .07 & 0 & 0.007 & 70 & .00 & 0 & .006 \\
\hline 13. CD Fish & 0 & 0.06 & 0 & .09 & 0 & .10 & 0 & .09 & 0 & 0.10 & 0 & .10 & 0 & .10 & 0 & 0.10 & 310 & .00 & 0 & .10 \\
\hline
\end{tabular}


Table 19

A Summary of the Yearly Performance:

Net Revenues and Aggregate Returns on Investment

\begin{tabular}{llccc}
\hline Year & $\begin{array}{l}\text { Net Revenue } \\
\text { Alternative }\end{array}$ & $\begin{array}{c}\text { Aggreg. } \\
\text { ROI\% }\end{array}$ & $\begin{array}{c}\text { Net Revenue } \\
\text { Alternative }\end{array}$ & $\begin{array}{c}\text { Aggreg. } \\
\text { ROI\% }\end{array}$ \\
\hline & & & & \\
1 & $60,068,000$ & 32 & $60,080,000$ & 32 \\
2 & $63,110,000$ & 34 & $62,550,000$ & 34 \\
3 & $56,690,000$ & 26 & $56,290,000$ & 15 \\
4 & $67,080,000$ & 30 & $67,030,000$ & 18 \\
5 & $91,990,000$ & 41 & $171,600,000$ & 45 \\
6 & $79,380,000$ & 36 & $144,300,000$ & 38 \\
7 & $83,150,000$ & 37 & $154,500,000$ & 40 \\
8 & $87,480,000$ & 39 & $160,800,000$ & 42 \\
9 & $91,240,000$ & 41 & $166,800,000$ & 44 \\
10 & $93,080,000$ & 42 & $166,600,000$ & 44 \\
& & & & \\
\hline
\end{tabular}

A summary of the yearly performance, shown on Table 19 , indicates that net revenues for both alternatives are nearly the same during the first five years, when the current conditions hold for both cases. Starting on year five of the simulation, when capacity increases are effected, the net revenues for Alternative A increase to approximately $150 \%$ of the initial level, and to approximately $300 \%$ of the initial level for Alternative $B$, while the aggregate rates of return on investment increase with reference to the initial rates by nearly $32 \%$ for Alternative $A$ and by $37 \%$ for Alternative B. 
3. Long-run Performance

The indicators of long-run performance are
a) gross output
b) employment
c) internal rate of return on investment

The total outputs and levels of employment associated with the ten year operation of the sector under the two alternatives are shown in Table 20, while a comparison of the initial and final output and employment levels are shown in Table 21, page 78 . The internal rate of return on the investment made on each zone is shown in Table 22, page 79.

Table 20

Ten Year Output of Fishery Commodities and Associated Employment as function of output

\begin{tabular}{|c|c|c|c|c|}
\hline \multirow[b]{3}{*}{$\begin{array}{l}\text { Type of } \\
\text { Product }\end{array}$} & \multicolumn{2}{|c|}{ ALTERNATIVE A } & \multicolumn{2}{|c|}{ ALTERNATIVE B } \\
\hline & & 玉mployment & & Employment \\
\hline & $\begin{array}{l}\text { Product Weight } \\
\mathrm{Q} \text { in } \mathrm{MT}\end{array}$ & $\begin{array}{l}\text { in Man Years } \\
\text { as } f(Q)\end{array}$ & $\begin{array}{l}\text { Product Weight } \\
\mathrm{Q} \text { in } \mathrm{MT}\end{array}$ & $\begin{array}{l}\text { in Man Years } \\
\text { as } f(Q)\end{array}$ \\
\hline Fresh & 980,000 & 116,114 & 890,000 & 105,450 \\
\hline Frozen & 170,000 & 16,521 & 410,000 & 39,844 \\
\hline Canned & 380,000 & 27,182 & 840,000 & 60,086 \\
\hline Fishmeal & $1,800,000$ & 5,812 & $1,600,000$ & 5,167 \\
\hline TOTALS & $3,330,000$ & 165,629 & $3,740,000$ & 210,547 \\
\hline
\end{tabular}


Summary of Annual Results

Capacity and Output (in Metric Tons per Year)

Employment as Function of Capacity

(in Man Years per Year)

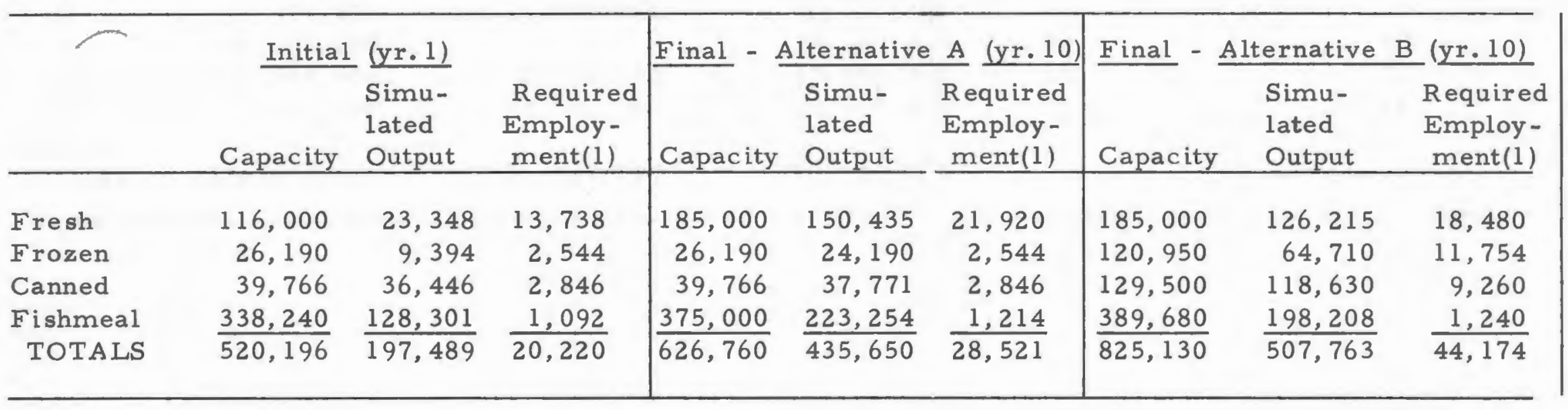

Notes. (1) as function of capacity. 


\begin{tabular}{|c|c|c|c|c|c|c|}
\hline \multirow[t]{2}{*}{ Zone } & \multirow[t]{2}{*}{ Current Investment } & \multicolumn{2}{|c|}{ Additional Inve stment } & \multicolumn{3}{|c|}{$\begin{array}{l}\text { 10-Year Internal Rate of Return } \\
\text { on Total Investment }\end{array}$} \\
\hline & & Alt. A & Alt. B & Alt. A & $\%$ & Alt. B \\
\hline I & $116,949,000$ & $1,781,000$ & $26,872,000$ & 34 & & 33 \\
\hline II & $8,424,000$ & $6,970,000$ & $36,778,000$ & 59 & & 50 \\
\hline III & $55,996,000$ & 0 & $38,950,000$ & 34 & & 30 \\
\hline IV & $4,275,000$ & $8,388,000$ & $19,555,000$ & 15 & & 18 \\
\hline $\mathrm{V}$ & $1,007,400$ & $3,388,000$ & $28,804,000$ & 23 & & 12 \\
\hline \multicolumn{7}{|l|}{ National } \\
\hline Total & $186,651,400$ & $20,527,000$ & $150,959,000$ & & & \\
\hline
\end{tabular}


4. Discussion of Results

Output Behavior

The outputs under both alternatives do not differ in the

first five periods. This is to be expected as the initial conditions are the same. Starting on period 5 and through to the end of the simulation differences exist in the composition of the output with a higher production of fishmeal for Alternative $A$ and higher production of frozen and canned products for Alternative B. As the extraction of fishery resources is increased nearly $100 \%$ (year 5 to the end of simulation) average output of fishery commodities increases by approximately $80 \%$ in Alternative $A$ and $100 \%$ for Alternative $B$, with the composition of average output broken down as shown in Table 23, page 81 .

As can be seen, the effect that the increase in capacity has on output is important but it is not the most important one. 
Table 23 - Impact of Capacity Change on National Output

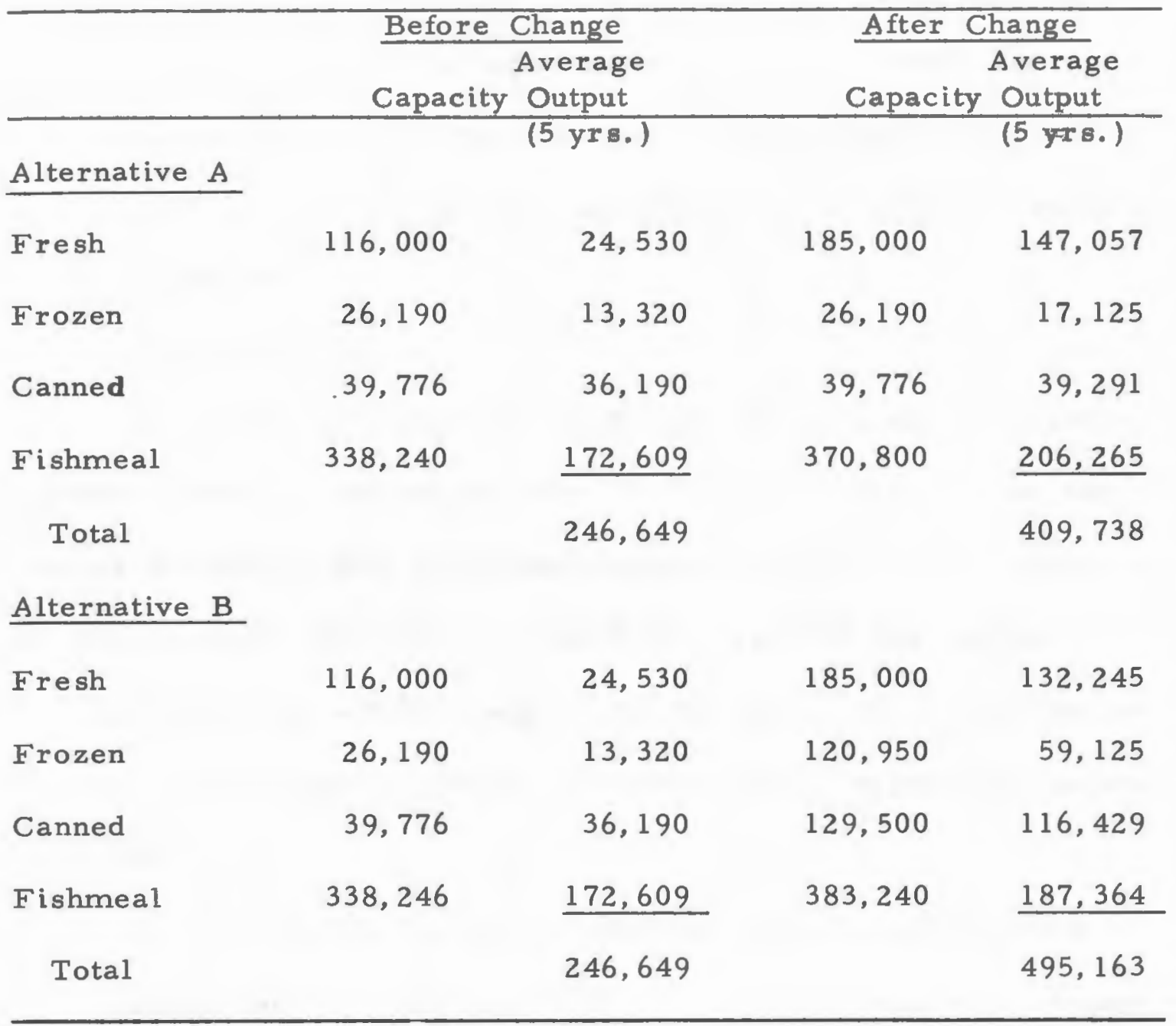

What really allows the increased production is the increased availability of fishery resources (nearly $200 \%$ of initial availability) particularly in zones where they were a constraining element under mitial conditions. This is apparent from the fact that under initial conditions simulated capacity utilization is quite low, except for the canning process.

The relation between the fresh and canned fish production in the initial years $(24,350$ tons to 36,190 tons) does not correspond 
to the current situation of the Chilean fisheries, (average fresh production is nearly 60,000 , while average canned production is nearly 12,000$)$. This is a sign that the relation between the prices used for these commodities over-values canned production, a clear indication of the weakness of the price information utilized for those commodities.

\section{Price Behavior}

The prices associated with the output of the different commodities produced, shown in Table 24, page 83 , reveal that for outputs of domestically consumed commodities that almost treble, the prices in the domestic market drop nearly $2 \%$ for canned products and experience an almost insignificant decrease for fresh jurel and merluza. The price of congrio however drops a significant amount (over $5 \%$ ).

It is clear that the price ratio between canned and fresh commodities does not correspond to reality, a nd implies a composition of consumption that overstates canned products by a factor of 3 . Furthermore, the price elasticity of demand for canned products, implied by the prices on Table 24 is another indication of the limited success that estimation efforts have had in these commodities. This is largely due to the quality of the aggregated information utilized which does not recognize the variety of canned fishery commodities.

The projected expansion of output implies a per capita 
Table 24 - Separable Programming Results:

Summary of Annual Output and Prices for Selected Commodities

(Outputs in Metric Tons, Prices in US\$/Ton)

\begin{tabular}{|c|c|c|c|c|c|c|c|c|c|c|}
\hline \multirow[b]{2}{*}{ Commodity } & \multicolumn{2}{|c|}{$\underline{1}$} & \multicolumn{2}{|c|}{2} & \multicolumn{2}{|l|}{3} & \multicolumn{2}{|c|}{4} & \multicolumn{2}{|c|}{$\underline{5}$} \\
\hline & $\mathrm{Q}$ & $\mathrm{P}$ & $Q$ & $\mathrm{P}$ & $Q$ & $\mathrm{P}$ & $Q$ & $\mathrm{P}$ & $Q$ & $\mathrm{P}$ \\
\hline \multicolumn{11}{|l|}{ Alternative A } \\
\hline Canned Prod & 36,446 & 2,418 & 35,991 & 2,418 & 36,267 & 2,418 & 36,055 & 2,418 & 39,763 & 2,416 \\
\hline Fresh Jurel & 0 & 167 & 0 & 167 & 0 & 167 & 2,030 & 167 & 76,910 & 136 \\
\hline Fresh Merluza & 49 & 283 & 174 & 283 & 53 & 283 & 0 & 283 & 0 & 283 \\
\hline Fresh Congrio & 3,432 & 690 & 3,554 & 688 & 3,433 & 690 & 3,093 & 694 & 5,602 & 670 \\
\hline Fresh OP & 9,003 & $*$ & 7,373 & $x^{*}$ & 9,000 & $*$ & 11,360 & $*$ & 41,480 & $*$ \\
\hline Fresh OD & 879 & $*$ & 1,186 & $*$ & 2,576 & * & 927 & $*$ & 16,690 & $*$ \\
\hline Frozen Prod & 9,394 & $*$ & 24,010 & $x^{k}$ & 9,709 & $*$ & 10,170 & $*$ & 15,400 & * \\
\hline Fishmeal & 128,301 & * & 174,037 & * & 79,047 & $*$ & 164,293 & $*$ & 240,989 & $*$ \\
\hline \multicolumn{11}{|l|}{ Alternative $B$} \\
\hline Canned Prod & 36,450 & 2,418 & 35,991 & 2,418 & 36,263 & 2,418 & 36,061 & 2,418 & 120,350 & 2,390 \\
\hline Fresh Jurel & 0 & 167 & 0 & 167 & 167 & 167 & 2,030 & 166 & 71,920 & 136 \\
\hline Fresh Merluza & 49 & 283 & 174 & 283 & 53 & 283 & 0 & 283 & 0 & 283 \\
\hline Fresh Congrio & 3,432 & 690 & 3,554 & 688 & 3,433 & 690 & 3,093 & 694 & 5,602 & 670 \\
\hline Fresh OP & 9,003 & $*$ & 7,373 & $*$ & 9,000 & $*$ & 11,360 & $*$ & 34,710 & $*$ \\
\hline Fresh OD & 879 & * & 1,186 & $*$ & 2,576 & $*$ & 927 & $*$ & 16,690 & $*$ \\
\hline Frozen Prod & 9,394 & * * & 24,010 & $*$ & 9,677 & $*$ & 9,470 & $*$ & 64,700 & $*$ \\
\hline Fishmeal & 127,971 & $*$ & 173,507 & $*$ & 78,704 & $*$ & 164,293 & $*$ & 219,115 & $*$ \\
\hline
\end{tabular}

$\begin{array}{llr}\text { * Parametric Prices: } & \text { Fresh OP and OD: } & \text { US\$375/MT } \\ & \text { Frozen Product(Merluza): } & 880 / \mathrm{MT} \\ & \text { Fishmeal and Oil: } & 272.5 / \mathrm{MT}\end{array}$


Table 24 (Cont.)

\begin{tabular}{|c|c|c|c|c|c|c|c|c|c|c|}
\hline \multirow[b]{2}{*}{ Commodity } & \multicolumn{2}{|c|}{6} & \multicolumn{2}{|c|}{$\underline{7}$} & \multicolumn{2}{|l|}{8} & \multicolumn{2}{|l|}{9} & \multicolumn{2}{|c|}{10} \\
\hline & $\mathbf{Q}$ & $P$ & $\mathbf{Q}$ & $P$ & $\mathbf{Q}$ & $\mathbf{P}$ & $\mathbf{Q}$ & $\mathbf{P}$ & $\mathbf{Q}$ & $\mathbf{P}$ \\
\hline \multicolumn{11}{|l|}{ Alternative A } \\
\hline Canned Prod & 39,765 & 2,416 & 36,920 & 2,417 & 39,766 & 2,416 & 39,763 & 2,416 & 39,771 & 2,416 \\
\hline Fresh Jurel & 86,940 & 131 & 73,520 & 137 & 80,000 & 131 & 79,440 & 131 & 69,270 & 136 \\
\hline Fresh Merluza & 2,075 & 282 & 1,385 & 282 & 79 & 283 & 2,514 & 282 & 1,009 & 282 \\
\hline Fresh Congrio & 8,645 & 638 & 8,280 & 640 & 7,085 & 650 & 8,871 & 636 & 8,096 & 643 \\
\hline Fresh OP & 23,650 & * & 39,520 & * & 25,880 & * & 36,590 & * & 43,420 & $*$ \\
\hline Fresh OD & 17,510 & * & 14,460 & * & 11,080 & * & 13,700 & * & 18,640 & * \\
\hline Frozen Prod & 9,190 & * & 9,190 & * & 24,190 & * & 24,190 & * & 24,190 & * \\
\hline Fishmeal & 149,450 & * & 159,979 & * & 234,111 & * & 229,879 & * & 223,254 & * \\
\hline \multicolumn{11}{|l|}{ Alternative B } \\
\hline Canned Prod & 111,263 & 2,393 & 115,500 & 2,392 & 115,594 & 2,392 & 117,240 & 2,391 & 118,630 & 2,391 \\
\hline Fresh Jurel & 97,260 & 131 & 60,920 & 141 & 80,090 & 131 & 82,380 & 132 & 58,000 & 143 \\
\hline Fresh Merluza & 2,075 & 282 & 1,385 & 282 & 79 & 283 & 2,514 & 282 & 1,009 & 282 \\
\hline Fresh Congrio & 8,645 & 638 & 8,289 & 640 & 7,085 & 650 & 8,871 & 636 & 8,096 & 643 \\
\hline Fresh OP & 7,210 & * & 29,360 & * & 10,640 & $*$ & 24,760 & * & 30,470 & * \\
\hline Fresh OD & 11,750 & * & 14,460 & * & 11,080 & * & 13,700 & * & 18,640 & * \\
\hline Frozen Products & 48,360 & * & 48,640 & * & 64,370 & * & 63,910 & * & 64,710 & * \\
\hline Fishmeal & 122,904 & * & 15,702 & * & 217,749 & * & 209,159 & * & 198,208 & * \\
\hline
\end{tabular}

* Parametric prices ( see previous page) 
consumption of fish of $23.25 \mathrm{~kg}$., that is twice the current one, with a composition that should remain constant unless the relative prices change significantly. That level of fish consumption should be based on price ratios to other food commodities that favor the consumption of fishery products, that is the price levels for these commodities would have to decrease.

An important element in the recognition of the relationship between price and quantity at the different marketing levels is a linkage between the demand faced by each (zonal) producer and the entire market demand. This element has not been included in this analysis, due to its limited scope. It would certainly be required in a more comprehensive application of the model proposed in this study. 


\section{Net Revenues and Return on Investment}

Net revenues during the first four years remain at a level near US\$60,000,000 for both alternatives $A$ and $B$, increasing after capacity expansion is effected to approximately US\$85,000,000 for alternative $A$ and to nearly US $\$ 160,000,000$ per year for alternative B. Static rates of return on investment differ from zone to zone, with the highest at $47 \%$ (Zone II) and lowest at $14 \%$ (Zone IV) before expansion. During the two years before expansion the ROI decreases significantly for some activities, as investment in expansion is effected on year 3 while the added output and revenue does not materialize until the end of year 5. This decrease in ROI levels is sharper for alternative $B$, where investment in expansion is heavier. After year five with the expansion of output and net revenues the rates of return increase above their initial levels for all zones. These increases are sharper in alternative $B$ for all zones except for zone V, where the increase in ROI is higher for alternative $A$.

\section{Interpretation of the Shadow Prices}

The shadow prices indicate the scarcity value of the constraints they are associated with, showing the potential contribution that a unitary relaxation of them would make to the objective function value.

Table 18 shows on a zone by zone basis the initial and final availability of unused slack and the shadow prices associated with each constraint. Examination of this table shows that the comple- 
mentary slackness property that falls out from the relationship between the primal of the maximization problem under consideration and its dual is met throughout. This property requires that the product of the value of each slack variable and its associated shadow price be zero. In practical terms it implies that if a constraint is not binding, i.e., if it has unused slack, its potential contribution to the objective function value has to be zero. If on $t$ he other hand, all the resource or capacity is used up, that is the value of the slack is zero, its potential contribution to the value of the objective function, given by the shadow price, must be equal to or greater than zero. Accordingly, the constraints the relaxation of which would contribute most to the value of our objective are, initially, the capacity for canning fishery products, particularly in Zone I and II which show shadow prices of 1200 and 600 US\$/ton of capacity expanded respectively.

Contrast between the final shadow prices of both expansion alternatives, indicate that the expansion considered for canning capacity in Zone I is more than required, while for zone II is insufficient, as there is still a high shadow price attached to that constraint after expansion. It can be also observed that as the catch is increased and processing capacity is held constant on Alternative A, the shadow price of canning increases in Zones II and III to its highest value, $1200 \mathrm{US} \$ /$ ton of capacity. Another important conclusion from the examination of the 
shadow prices is that only in Zone $\mathrm{V}$ there exists some scarcity of fishmeal processing capacity, and as evidenced by the value of the slack variable, there is considerable over capacity, particularly in Zones I and III.

The apparent attractiveness of the canning process as suggested by the high shadow prices must be taken with some reservation, as this is due to the high price used for canned products in relation to the other commodities, particularly to fresh products. If as indicated earlier the relative prices are biased towards canning, this suggestion could prove quite misleading. The validation of the prices utilized is an important pre-requirement to the application of the model's results since the accuracy of the signals given by the shadow prices will not be better than the accuracy of the prices used to run the model.

Long-Run Results

The simulated operation of the fisheries economic system during a ten year period yields results, shown in Table 20 and 21 , that indicate that aggregate capacity utilization after expansion is nearly $70 \%$ for Alternative $A$ and $60 \%$ for Alternative $B$, and that final employment as a function of capacity output is 2.2 times greater than initial employment for expansion Alternative B and 1.4 times greater for Alternative A. Employment as function of the simulated ten year output however is nearly twice as great for Alternative B, with both expansion alternatives exceeding current output levels by 
margins of 100 to $200 \%$.

Investment required for the expansion of production capacity (table 15) adds to US $\$ 20,527,000$ for Alternative $A$ and US $\$ 150,959,000$ for Alternative B. Internal rates of return on the total investment tied down in processing are higher for expansion Alternative $A$ in zones I, II, III and V, and for expansion Alternative B in zone IV. Sensitivity Analysis Results

The sensitivity of the system's performance was tested under two types of changes:

- flat increases or decreases in the net revenues per unit from the production and marketing of all commodities

- consideration of different objective functions for the different zones, recognizing the different costs of transportation that different zones would face in reaching the Santiago market. (The net revenue functions associated with the production in each zone are shown in Appendix D.)

The effect of increases or decreases in unitary net revenues did not change the level nor composition of the outputs, although as expected net revenues and returns on investment did increase or decrease by the same proportion that net revenues per unit were changed.

The effect of int roducing different objective functions for each zone on the output and net revenues is described below: 
Output Behavior Under Zonal Objective Functions

The level and composition of output that result from the operation of the model with different objective functions for each zone (Appendix E) changes since the attractiveness of the production of several commodities in zones away from the center becomes adversely affected by the costs of transportation to the reference market (central zone).

As in the case of single objective functions, the resulting composition of output shows an output ratio between canned and fresh products that is much greater than the ratio encountered in the operation of the real life system.

A notable difference in these results as opposed to those obtained under a single objective function, is that the optimal outputs are the same for the two expansion alternatives, showing only a response to the expansion of raw material availability, and none to the different extent of expansion of capacities for processing canned or frozen products. This indicates that contribution to the objective functions rather than the capacity constraints are limiting output, as in all cases the variable cost of transportation eventually limits the attractiveness of production.

In this case as well as for the operation under a single objective function, interyear variation in output levels is due to the randomly generated variation in the catch available for processing and secondly to the fact that after year five, the level of the catch 
available for processing is doubled.

The level of output of fresh commodities is significantly lower for the results of the model run under different objective function for each zone than under one aggregated objective function. This is to be expected as these commodities are the most severely affected by transportation and refrigeration costs.

Net Revenue and Return on Investment under Zonal Objective Functions.

Initial levels of the net revenue and returns on investment under this condition (Appendix F) are lower than for a single objective function. The use of zonal objective functions makes the increase in resource availability improve considerably the profitability of Zones II to III, by expanding their output and revenues from those commodities that are not affected by transportation costs. Under expansion alternative $B$ net revenues remain at the same level as in expansion alternative $A$, with a higher investment tied down, yielding therefore lower rates of return, in several cases below the initial ones.

5. Accuracy and Reliability of Results

The application of the separable programming model to the simulation of the economic system formed by the fisheries and related activities provides a reasonably close replication to its real life operation, but has not yet become an accurate tool for predicting the behavior of the system. Its main wekness has been 
its failure to reflect real life output composition. This is due mainly to the quality of the input information, particularly the prices of canned commodities and their sensitivity to changes in output, and to a lesser extent production costs. Improvement of the input data and validation of results constitute an iterative fine tuning process that is required for the improvement of the results from the application of this model. 
CHAPTER IV

CONCLUSIONS AND POLICY RAMIFICATIONS

\section{Summary of Results}

The most important conclusion from the first chapter is that there exists and important potential for the expansion of the physical production of the Chilean fisheries. Another conclusion is that this physical potential has not been realized, in part due to lack of information on the profit potential of investment in such activities, and in part due to lack of some services (usually of governmental provision) and infrastructure required for the successful expansion of productive activities.

The simulated operation of the fisheries economic system has given the following results:

a) as the extraction of fishery resources is expanded to meet their availability in Chilean waters, investment in the production of commodities from them offers returns on investment that are quite attractive for some zones and processes, with internal rates of return on the overall investment tied down that range from $12 \%$ to $59 \%$. Expansion of existing processing capacitities enhances the already achieved profitability of investment in processing facilities only in the central and southern zones, while in the other zones profitability of invest- 
ment decreases slightly if capacity is expanded. The existing over-capacity for fishmeal processing in Zones I and II exceeds the requirements of the expanded extraction and would allow for reductions of up to $25 \%$ to $30 \%$.

b) under the estimated market conditions output may be doubled and even trebled at attractive levels of return, for those commodities that have an outlet in the domestic market alone. The consideration of international market opportunities would make returns on investment in the production of these commodities more attractive yet.

c) the employment implications of the expansion of the production of fishery commodities are different for different output mixes. As fishmeal is the least labor intensive process, expanding its output makes the least contribution to employment. On the opposite extreme, fresh extraction, freezing and canning provide the higher needs for labor services, in that order.

d) the estimated investment required to expand fishery commodity production is approximately 20 million dollars for Alternative $A$ and nearly 150 million for Alternative B. The internal rates of return associated with the total investment tied down on each zone are higher for Alternative $A$ in all but one case (Zone IV), 
suggesting the convenience of holding the investment constant and expanding the utilization of existing facilities, improving therefore the profitability of investment already tied down in those facilities.

\section{Qualifications}

The stated results are valid for the following conditions:

a) fishery stocks and sustainable yields as estimated by IFOP 27

b) assumptions underlying simulation of fisheries extraction (independence of fish populations, random distribution of deviations from expected catch, etc.) hold.

c) assumptions underlying the separable programming model (i.e. profit maximizing behavior on the part of processors, processing activity at zonal level reflected by single operator's behavior, etc.) hold

d) cost and demand functions utilized in this study (Appendix B)

e) availability of port and road infrastructure as required to land and distribute the output of fishery commodities Of these conditions the most weakly met is d), therefore 
these results must be considered with much reservation. Their sensitivity to price relations requires that more extensive research be done on the demand and cost function used to run the model. In its present state the results from the application of this model can best be regarded as providing useful information on the relative advantage of investment in different zones. However, improvements in the cost and price data utilized to run the model are required before it can be used as a tool for assessing the relative advantage of investment in the production of different commodities or predicting the system's performance.

\section{Policy Ramifications}

Given the national objectives of fishery exploitation and in the light of the results of the analysis performed, the following recommendations would seem in order:

- given the availability of marine fish resources, efforts should be encouraged to exploit them rationally to their full potential, providing the fishery management and research required to generate such activity and prevent overexploitation. - along with the expansion of the supply of fishery commodities efforts should be made to shift the demands for the se commodities in the domestic market.

- research on the costs and benefits associated with the governmental investment in the provision of services and 
infrastructure required for the production and marketing of fishery commodities should be carried out.

- given the zonal availability of processing facilities and the concentration of fishery resources, services such as ports and transportation infrastructure should be made available so as to encourage the investment in processing facilities where required.

- marketing services should be provided to ensure the timely dissemination of information on prices for both domestic and export commodities.

The operation of the sector's extractive processing and marketing activities should be left to private activity, ensuring however, that resources are not overexploited and that competition is not hampered.

4. Limitations of the Present Study Price and Cost Information

Prices are the most critical set of data required for the application of the model utilized in this study. The information available on the domestic prices of Chilean fishery commodities is limited in the number of observations and there are some questions as to its accuracy. Because of the complexity of the Chilean economy a host of other variables should be considered in their estimation. A comprehensive demand study should provide more 
sophisticated economic estimators of demand. The focus of this study and the nature of the information available have not warranted, however, a more rigorous effort at demand and cost estimation. Pricing of export commodities (fishmeal and frozen products) has been parametric.

The reader is warned, therefore, about the questionnable accuracy of the estimated costs and prices, which are determinant for the composition of the optimal outputs, and for the profitability of the different investment patterns. Also troublesome for the latter is the estimation of the current and required investments. There is a strong possibility that the estimations of current investments are overvalued, and that needed investment is undervalued, making returns on investment appear more attractive than what they are really. Model Structure

The structure of the separable programming model as utilized in this study implies the following assumptions:

- productive activities in each zone are represented by a single profit maximizing producer, that has the option to sell fish fresh, frozen or canned, or to reduce to fishmeal the catch available to him. Processors in all zones face the same demand functions for commodities sold in the domestic market, or parametric prices for export commodities.

- There is one domestic market where fresh and canned 
products are consumed and one export market that buys the outputs of fishmeal and oil and frozen products. Abstraction is made of spatial relationships between supply and demand centers, although this is partially considered in the sensitivity analysis.

- there is a single activity in the extraction of the fishery resources and their transformation into each of the 25 fishery commodities considered.

5. Extension of Economic Research on the Production of Fishery Commodities in Chile

After some adjustment in the input data (cost and prices) the model presented in this study can give results that are reasonably useful for governmental policy and private investment decision making.

To make this tool a more accurate simulator of economic performance and improve its reliability for the analysis of investment, the following improvements would be required:

- efforts should be spent on the development of substantially more detailed cost and price information with which to feed the model

- disaggregation of zonal rates of returns by process to yield more information on the attractiveness of specific investment opportunities in fresh, frozen, canning, or reduction processes within each zone 
- different stages in the replication of the processors behavior should be considered and linkages should be provided between the resolution of the separable program at the national level and its resolution at the zonal levels

- zonal disaggregation of processing activities should be coupled to zonal disaggregation of marketing activities - Each of these should recognize the demand and supplies at each locale and their spatial relationships.

- performance in different periods could be linked in a sequential manner so that the results of the operation in one period be made use of in the next period, e.g., making investment in one period function of the shadow prices that fall out from the optimal solution of the programming problem in the previous period

- consideration should be made of other inputs or resources utilized in the production of fishery commodities, such as labor, that may or could become scarce on a regional context. 


\section{BIBLIOGRAPHY}

[1] Achurra M., and A. Couve. La Mano de Obra en el Sector Pesquero de Chile. FAO, Rome, 1971 .

[2] Adriasola, L.A. "Situacion Actual y Potencial de Desarollo del Sector Pesquero en Chile: Analisis Preliminar," Centro de Planeamiento, Santiago, July, 1975.

[3] Almenas, K.K., et al. Engineering Economic Model for Fish Protein Concentration Processes. National Marine Fisheries Service, Seattle, Washington, 1972.

[4] Bakovic and Balik/ESPES. Estudio de Racionalizacion de la Industria Pesquera CORFO de la Zona Norte: Santiago, November, 1974.

[5] Barros, 0. Investigacion Operativa y Analisis de Sistemas, Volumen I, Facultad de Ciencias Fisicas y Matematicas, Universidad de Chile, Sede Occidente, Santiago: Editorial Universitaria, 1974.

[6] Barros, O., and L.A. Adriasola. "Un Modelo para la Simulacion del Sector Pesquero en Chile," Centro de Planeamiento, Santiago, December, 1975.

[7] Barros, O., J. Escudero, J. Majluf, and R. Riverso. Diseno de un Sistema de Distribucion de Productos del Mar, Centro de Planeamiento, Fac. de Ciencias Fisicas y Matematicas de la Universidad de Chile, Santiago, 1973.

[8] Basaure, V. Luis, and Ruperto F. Cabello. Elaboracion de Embutidos a Base de Pulpa de Pescado. Instituto de Fomento Pesquero, Santiago, Chile, December, 1973.

[9] Cade, Consultores en Administracion de Empresas. Comercializacion de Pescados y Mariscos en el Gran Santiago, Vol. I al IV. Santiago, 1967.

[10] Campleman, G. A Preliminary Report on Fisheries Development and Planning in Chile, Santiago, Chile, I971.

[11] . "Chile: the Last Frontier of Fisheries Expanson," Fishing News International, Vol. 14, No. 9, September, 1975, p. 37. 
[12] Comision Coordinadora del Sector Pesquero-CORFO.

Informe Final Subcomision de Abastecimierto, Comercializacion y Consumo de Productos de $\perp$ Mar, CorFo, Santiago, March, 1971.

[13] Comision Coordinadora del Sector Pesquero-CORFo. Informe Final, Subcomision de Puertos, Corporacion de Fomento, Santiago, 1971.

[14] Comite Economico para America Latina Naciones Unida:. Manual de Proyectos de Desarrol to Economico. Moxico, December, 1958.

[15] Comite Sectorial Pesquero. Plan de Desarrollo Industrial Pesquero, Documento de Discusion, Departamento de Planificacion e Ingenieia y Desarrollo, Corporacion de Fomento, Santiago, 1972.

[16] Couve, Andres R. Consideraciones para el Desarrollo Integral de la Pesca en Chile, Seminario Sobre la Actividad Pesquera, Universidad Catolica de Valparaiso, 1972 .

[17] Crutchfield, J.A. Economics of Frozen Fish Marketirug; Freezing and Irradiation of Fish. FAO/Fishing Hews (Books) Ltd., London, 1969.

[18] Dazarola, Gabriel M. Perspectivas de Desarrolla de la Acuicultura. Deminario Sobre las Perspectivas de Desarrollo del Sector Pesquero Chileno, Universidad Catolica de Valparaiso, 1974.

[19] Eberhard, P., and R. Cerda. Perspectivas de Desarrollo de la Pesca Semi-Industrial en Chile, Seminario Sobre las Perspectivas de Desarrollo del Sector Pesquero Chileno, Universidad Catolica de Vaiparaiso, 1974.

[20] FAO. Anuario Estadistico de Pesca, Vol. 36, Capturas y Desembarques 1973. Food Agricultural Organization of the UN, Rome, Italy, 1974.

[21] FAO Jituacion y Perspectivas de los Productos Basicos 1972-73. Food and Agricultural Organization of the UN, Rome, Italy, 1974.

[22] FAO Fishing Commodities Review and Outlook 1972. Vol. 35. FAO, Rome, Italy, 1973.

[23] Gomez, A., and L.A. Adriasola. "El Papel del Analisis Economico y de Sistemas end el Estudio de las Pesquerias Antesanales," Centro de Planeamiento, Santiago, October, 1975. 
[24] Gomes, H., J. Santos, and J. Steel. Elaboracion de Camarones y Langostinos Congelados y en Conserva. Instituto de Fomento Pesquero, Santiago, Chile, 1969.

[25] Gonzalez, L.E., J.M. Hernandez, S. Santa Crui, ami $\because$. Silva. Perspectivas de Desarrollo de la Conquicultura en Chile. Seminario Sobre las Perspectivas de Desarrollo del Sector Pesquero Chileno. Universidad Catolica Valparaiso, September, 1974.

[26] Gross, M., M. Valenzuela, E. Corbalan, A. Sepulveda, J. Torres, and D. Downey. Diagnostico de la Pesca Artesanal en Chile. Instituto de Desarrollo Agropecuario, INDAP., Santiago, 1968.

[27] Guzman, Oscar F. Situacion y Perspectivas de la Explotacion de los Principales Recursos Pesqueros de Chile. Seminario Sobre las Perspectivas de Desarrollo del Sector Pesquero Chileno, Universidad Catolica de Valparaiso, 1974.

[28] Hadley, G. Linear Programming. Reading, Mass.: Addison Wesley Publishing Co., 1963.

[29] - Non Linear and Dynamic Programming. Reading, Mass.: Addison Wesley Publishing Co., 1964.

[30] Hancock, Donald A. La Pesqueria de Mariscos en Chile. Instituto de Fomento Pesquero, Santiago, Chile, 1969.

[31] Heen, E. Specific Problems and Techno-Economic Considerations in the Shore Based Fish Freezing Industry. Freezing and Irradiation of Fish, FAO/Fishing News (Books) Ltd., London, 1969.

[32] Henriquez, L., I. Asenjo, H. Gomez, and C. Varela. Estudio de las Posibilidades para Aumentar la Produccion de Filetes de Merluza Congelados para Exportacion en San Antonio. Instituto de Fomento Pesquero, Santiago, 1972.

[33] Herrera, L.P., Utilizacion de Recursos Marinos en Alimentos no Convencionales. Seminario Sobre las Perspectivas de Desarrollo del Sector Pesquero Chileno, U.C.V., Valparaiso, 1974. 
[34] Ibaceta, Marta. Algunos Aspectos de los Habitos de Consumo de Pescados y Mariscos y su lncidencia er el Envase. Instituto de Fomento Pesquero, SanEiago, Chile, 1973.

[35] Ibaceta, Marta, and Salvador Yates. Comercializacion y Mercado Interno de la Harina de Pescado en Chile, Instituto de Fomento Pesquero, Santiago, Chile, 1971 .

[36] Instituto de Fomento Pesquero (IFOP). Lista de Publiciacaciones del Instituto de Fomento Pesquero (IF'OP). Santiago, Chile, 1974.

[37] Instituto Nacional de Estadistica. Agricultura E Industrias Agropecuarias y Pesca. geveral issues from 1960 to 1970. Santiago, Chile.

[38] IBM Technical Publications Department. Mathematical Programming System/360, Version 2, Linear and Separable Programming User's Manual. White PLains, New York; 1968.

[39] - System/360 Scientific Subroutine Package, Version 2, Programmer's Manual. White Plains, New York, 1967.

[40] IFOP, Departamento de Economia. Datos Estadisticos de la Industria de Reduccion de Anchoveta, 1968.

[41] IFOP, Sèccion Estudios de Mercados. Informe sobre la Operacion de un Carro Movil para la Venta de Pescados y Mariscos y Resultados Obcnidoes. Instituto de Fomento Pesquero, Santiago, Chile, June, 1973.

[42] IFOP, Departamento de Estudios Economicos, Division Estudios de Mercado. Informaciones Generales de Interes para Exportar Productos Pesqueros. stituto de Fomento Pesquero, Santiago, Chile, April, 1970.

[43] IFOP, Departamento de Estudios Economicos, Seccion Economia Pesquera. Caracteristicas y Tendencias de la Industria Pesquera para Consumo Humano, 1967-70. Instituto de Fomento Pesquero, Santiago, Chile, December, 1971.

[44] IFOP, Departamento de Estudios Economicos. Chile: Nomina de Empresas Pesqueras y Direcciones de slis Plantas y Gerencias Comerciales, Scgun cl Tino de Actividad que Desarrollan. Instituto de Fomento Pesquero, Santiago, Chile, June, 1970. 
[45] IFOP, Departamento de Technologia. Manipulacion de Merluza a Bordo, IFOP, Santiago, Chile, 1971.

[46] IFOP. Nueva Estructura Organico-Administrativa. Instituto de Fomento Pesquero, Cantiago, Chile, 1973.

[47] IFOP. Plan Operativo Preliminar 1974. Santiago, Chile, $197 \overline{73}$

[48] Kreuzer, R., Ed. Freezing and Irradiation of Fish. Fishing News (Books) Ltd., London, 1969.

[49] Lampe, H.C., and M. Afurra. Estudio del Comercio Regional y Extraregional de Productos Pesqueros

Latino Americanos. Banco Interamericano de Desarrollo y Organizacion de las Naciones Unidas para la Agricultura y Alimentacion, FAO, Washington, 1971 .

[49] Lampe, H.C., and F.J. Farrell. The New Engliand Fishing Industry: Functional Markets for Finned Food Fish I and II. Department of Resource Economics, University of Rhode Island, 1965.

[50] Lennon, C.0. A Corporate Planning Model of the Irish Sea Fishing Industry. 7 th International Confercnce of Operations Research, Tokyo, Kyoto, Japan, 1975.

[51] Liebeschutz, M., and H. Aliaga. Inversiones y Capacidad de Produccion en la Industria de Harina de Pescado en el Norte de Chile, Un Modelo Matematico para su Racionalizacion. Instituto de Fomento Pesquero, Santiago, Chile, 1966.

[52] Luna, J. Informe sobre Orientaciones para un Plan Sectorial de DeSarrollo Pesquero en Chile. Banco Interamericano de Desarrollo, February-March, 1971.

[53] Massachusetts Institute of Technology. The Economics of Fish Protein Concentrate, MIT, Boston, Mass., 1970.

[54] Mery, J., and D. Meyer. Consideraciones Economico-Tecnicas de Desarrollo del Sector Pesquero en Chile. Instituto de Fomento Pesquero, Santiago, Chile, 1972.

[55] Miranda, M. Obtencion de Concentrados Proteicos Solubles $y$ de Sustitutos Lacteos Para Consumo Humano y Arimal. Seminario Sobre las Perspectivas de Desarrollo del Sector Pesquero Chileno, Universidad de Catolica de Valparaiso, Chile, 1974. 
[56] NMFS Market Research and Services Division. Food Fish Market Review and Outlook. National Marine Fisheries Service, Washington, D.C., May, 1974.

[57] NMFS Market Research and Services Division. Industrial Fishery Products, Market Review and Outl.ok. National Marine Fisheries Service, Washington, D.C., May, 1974.

[58] NMFS Market Research and Services Division, Current Economic Analysis S-27. Shellfish, Market Reviev and Outlook, NOAA, U.S. Department of Commerce, Washington, D.C.

[59] ODEPLAN. Cuentas Nacionales de Chile 1965-72, Santiurro, 1974.

[60] ODEPLAN. Informe Economico ano 1974, Santiago, 1975.

[61] Ovenden, A.E. Investigaciones sobre Costos y Beneficios en las Industrias Pesqueras Primarias, un Estudio de los Conceptos y Definiciones. FAO, Rome, 1961 .

[62] Purcell, Maschke, A. Comercializacion de Conservas de Pescado en Chile. Instituto de Pomento Pesquero, Santiago, 1969.

[63] Purcell, Maschke, A., and J. Viel. El Mercado Nacional y los Principales Mercados Internacionales para Pescados y Mariscos Congelados Chilenos, Instituto de Fomento Pesquero, Santiago, 1970.

[64] Rasmussen, C.L. Economic Appraisal of Different Freezing Methods. Freezing and Irradiation of Fish, FAO/Fishing News (Books) Ltd., London, 1969.

[65] Roe, Terry L. "Modeling of Nonlinear Functions irto a Linear Programming Format, Staff Paper \#P75-9, Department of Agriculture and Applied Economics, University of Minnesota, St. Paul, Minnesota, June, 1975.

[66] Robles, F. La Oceanologia en Chile y Sus Perspectivas de Desarrollo, Documento Preliminar, CONICYT, Santiago, 1970 .

[67] Sanhueza, W.R., L. Toro, A., A.J. Muga, and P.J. Sal.a.. Perspectivas de Desarrollo de la Industria Pesquera Chileno. Universidad Catolica de Valparaiso, 1974. 
[68] Servicio Agricola y Ganadero, Division de Pesca y Caza. Anuario Estadistico de Pesca, 1970-1971. Ministerio de Agricultura, Chile, 1973, 1974.

[69] Servicio Agricola y Gandero, Division de Pesca y Caza. Sintesis Estadistica de Pesca, 1972-1973. Ministerio de Agricultura, Santiago, 1973, 1974.

[70] Sintesis Estadistica. Several Issues 1970 to 1975, Santiago, Chile.

[71] Stansby, M.E., Ed. Industrial Fishery Technology. Reinhold Publishing Co., New York, 1963.

[72] Viel, J., R. Claro, and S. Yates. Comercializacion y Mercado de Productos Pesqueros Originarios de las Provincias de Llanquihue, Chiloe y Aysen. Instituto Fomento Pesquero, Santiago, Chile, 1973.

[73] Viel, J., and S. Molina. Posibilidad de Mercado en Bolivia, Peru y Chile segun Preparaciones Desarrolladas por IFOP para Conservas de Pescados y Mariscos. Circular \#71, Instituto de Fomento Pesquero, Santiago, Chile, 1971.

[74] Waugh, F.V., and V.J. Norton. Some Analysis of Fish Prices. University of Rhode Island Agricultural Experiment Station, Kingston, R.I., 1969. 
Common Spanish Name

Agujilla

Anchoveta

Atun alets amarilla

Atun aleta larga

Azulejo

Bacalao de Juan Gernandez

Bacalao de profundidad

Blanquillo

Bonito

Breca de Juan Fernandez

Brotula

Caballa

Cabinza

Cabrilla

Cachurreta

Chancharro

Cojinova

Congrio colorado

Congrio dorado

Congrio negro

Corvina

Jurel

Lenguajo

Lisa

Lisa del norte

Machuelo

Marrajo

Merluza

Merluza espanola

Merluza de cola

Merluza je tres aletas
Rough English Equivalent

Scientific Name

\section{Saury \\ Anchovey \\ Tuna \\ Tuna \\ Cod \\ Cod}

Bonito

Cusk eel

Cusk eel

Cusk eel

Mackerel

Sole

Hake

Hake

Grenadier

Hake
Scombersox stolátus

Engraulins ringen

Thunus albacares

Thunus ala lunga

Prionace glauca

Polyprion oxygeneius

Dissostichus amissus

Prolatilus jugularis

Sarda chilensis

Chilodactilus gayi

Salilota australis

Pneumatophorus peruanis

Isacia conceptionis

Sebastodes oculatus

Helicolemis lengerichi

Euthymus pelamis

Sebastodes chilensis

Neptomenus crassus

Genypterus chilensis

Genypterus reedi

Genypterus maculatus

Cilus montti

Trachurus murphyi

Paralichtye microps

Mugil cephalus

Mugil curema

Icevoontia maculata

Isufus Oryrinchus

Merluccius cryi gayi

Merluccius polylepis

Miacruronus magellanicus

Micronesistius australis 
Pejegallo

Pejerrey

Pez espada

Reineta

Robalo

Saruina comun

Sardina espanola

Sardina de los canales

Sierra

Tollo

Vidriola de Juan Fernandez

Smelt

Swordfish

Pilchard

Pilchard

Herring

Snake mackerel

Shark

\section{Almeja}

Clam

Berberecho

Calamar

Camaron

Centolia

Cholga

Chorito

Choro

Erizo

Jaiva mora

Jaiva peluda

Jibia

Langosta de Isla de Pascua Langosta de Juan Fernandez

Langostino amarillo

Langostino colorado

Loco
Lobster

Lobster

Snail
Callorhynchus callorhynchus odontesthes regia

Xiphias gladius

Lepidotus australis

Eleginops maclovinus

Strangomera bentincki

Sardiros sagax musica

Clupea fueguensia

Thyrsites atun

Mustelus mento

Seriola mazatlana

Protothaca thaca

Ameghinomya antigua

Tagelus dombeii

Loligo gahi

Heterocarpus reedi

Lithodes antarctica

Aulacomya ater

Mytilus edulis chilensis

Choremytilus chorus

Loxechimus albus

Homalaspis plana

Cancer cetosus

Dosidicus gigas

Palinurus pascuensis

Jasus frontaiis

Cervimunid ionni

Plevirancodes l.unjan

Conchalenas concholenas 
Common Spanish Name

Macha

Ostion

Ostra

Picoroco

Piure

Pulpo

Taca

Kril1
Rough English Equivalent

Clam

Oyster

Squid
Scientific Name

Mesodesma donacium

Chlamys argopecten purpurata

Ostrea chilensis

Megabalamus psittacus

Pyura chilensis

octopus vulgaris

Protothaca thaca

Eupheusia superba

Source: Guzman, op.cit., p. 131. 


\section{APPENDIX B}

Prices and Costs for Chilean Fishery Comnodities

1. Prices, or price relationships

( $P$ in $1975 \mathrm{US} \$ /$ metric ton $-Q$ in metric tons)

Fresh Commodities

(1)

Congrio

Merluza

Jurel

Other Pelagic

Other Demersal

Processed Commodities

Canned Commodities

Frozen Commodities

Fishmeal

Fish Oil

$$
\begin{aligned}
& P=724-.00099 Q \\
& P=283-.000027 Q \\
& P=167-.000039 Q \\
& P=375 \\
& P=375
\end{aligned}
$$

(2)

$$
\begin{aligned}
& P=2430-.00034 Q \\
& P=880 \\
& P=220 \\
& P=300
\end{aligned}
$$

Notes: Costs, Prices and Price Relationships developed from information collected from:

(1) Sociedad de Terminales Pesqueros - Corporacion de Fomento de la Produccion - Santiago, Chile.

(2) U.N./F.A.O. Statistical Yearbook, several years. 


\section{Appendix B (Continued)}

2. Average Production Cost ${ }^{(3)}$, in US\$ 1975 per metric ton of product

\begin{tabular}{l|c|c|c|} 
& $\begin{array}{c}\text { Average } \\
\text { Variable } \\
\text { Cost }\end{array}$ & $\begin{array}{c}\text { Average } \\
\text { Fixed Cost } \\
\text { at Capacity }\end{array}$ & $\begin{array}{c}\text { Average Total } \\
\text { Cost at Capa- } \\
\text { city Output. }\end{array}$ \\
\hline Fresh Commodities & 218.4 & 50 & 268.4 \\
Frozen Commodities & 393 & 240 & 633 \\
Canned Commodities & 510 & 14 & 524 \\
\hline
\end{tabular}

(3) IFOP, Seccion Estudios Economicos, and Bakovic and Balic/ESPES op.cit. 
- List of Separable Programming Variables

No. Description

Tpye

I ANCN

2 ANCNL

3 ANCN2

4 ANCN3

5 ANCIN4

6 ANCN5

7 ANEM

8 ANFMI

9 ANFM2

10 ANFIM 3

11 ANFM4

12 ANFM5

13 JUSFS

14 JUSFSI

15 JUSFS2

16 JUSFS 3

17 JUSFS4

18 JUSFS5

19 JUSFZ

20 JUSFZI

21 JUSFZ2

22 JUSFZ3

23 JUSFZ4

24 JUSFZ5

25 JUSCN

26 JUSCNI

27 JUSCN2

28 JUSCN3

29 JUSCN4

30 JUSCN5

31 JUSFM

32 JUSFMI

33 JUSFM2

34 JUSFM3

35 JUSFM 4

36 JUSFM5

37 SARFS

38 SARFSI

39 SARFS2

40 SARFS 3

41 SARFS4

42 SARFS5
Canned Anchoveta Production

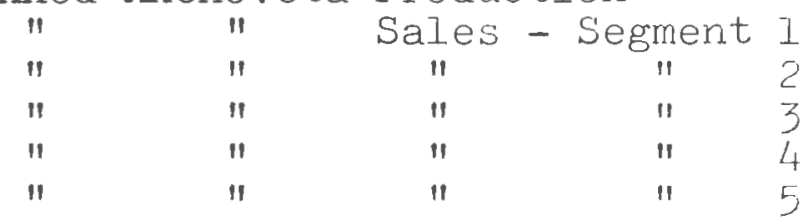

real

Anchoveta Fish Meal Production

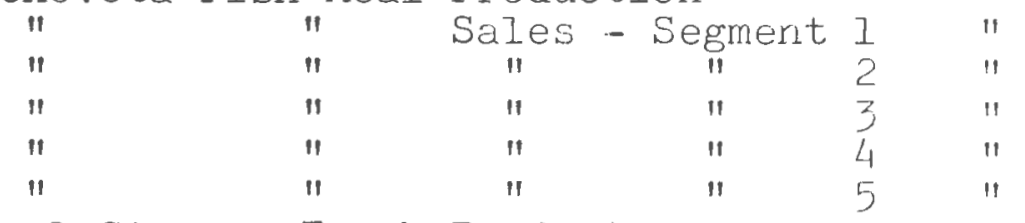

Jurel Sierra, Fresh Broduction

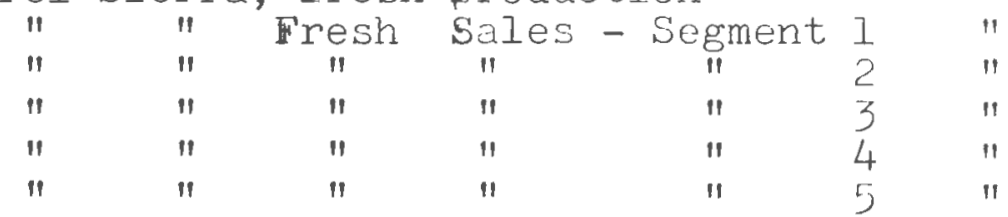

Jurel Sierra, Frozen Production

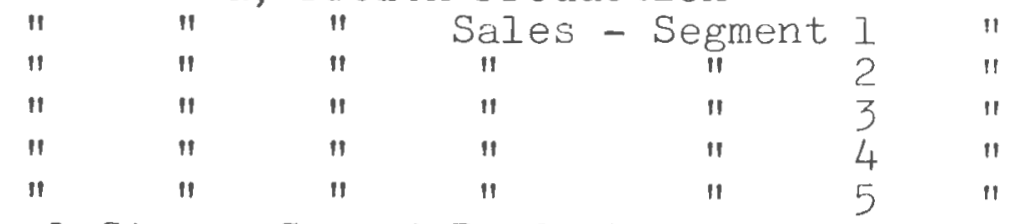

Jurel Sierra Canned Production

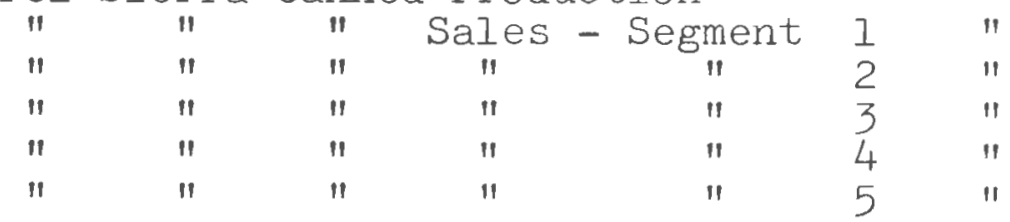

Jurel Sierra Fish Meal Production

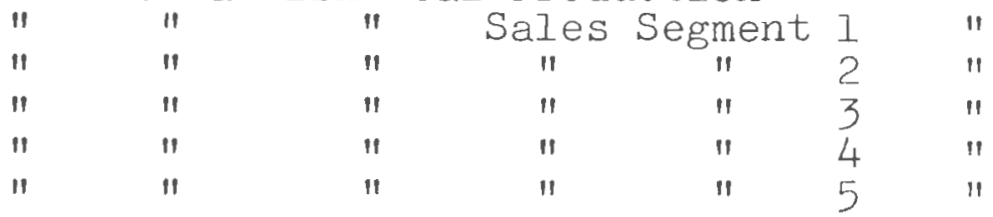

Fresh Sardina Production

\begin{tabular}{|c|c|c|c|}
\hline " & $" 1$ & Sales & - Segment \\
\hline " & $"$ & $"$ & "I \\
\hline " & $"$ & $"$ & $"$ \\
\hline 11 & $"$ & $"$ & $"$ \\
\hline
\end{tabular}

11
11
11
11 
Appendix C - (Cont.)

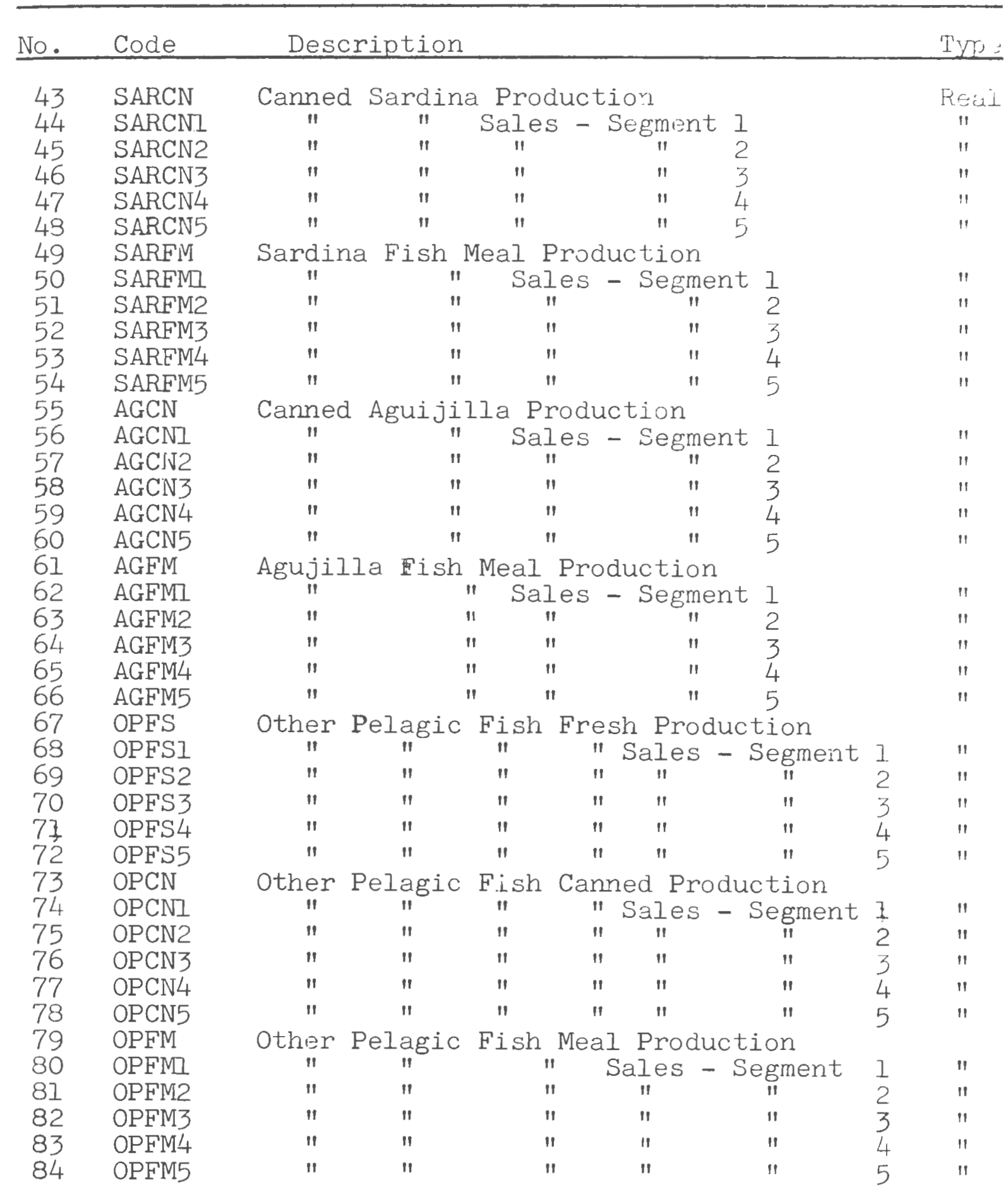


Appendix C - (Cont.)

No.

Description

Type

\begin{tabular}{|c|c|c|c|c|c|}
\hline 85 & MZFS & Fresh & Merluza & Produc & tion \\
\hline 86 & MZFSI & 11 & 11 & Sales - & Segment \\
\hline 87 & MZFS2 & 11 & "I & $"$ & 11 \\
\hline 88 & MZFS3 & $" 1$ & $" 1$ & $"$ & " \\
\hline 89 & MZFS4 & $" 1$ & $" 1$ & $" 1$ & " \\
\hline $90 \mathrm{q}$ & MZFS 5 & 11 & $" 1$ & $"$ & 11 \\
\hline
\end{tabular}

$\begin{array}{ll}1 & " 1 \\ 2 & 11 \\ 3 & 11 \\ 4 & 11 \\ 5 & 11\end{array}$

91 MZFZ

92 MZFZI

93 MZFZ2

$94 \quad$ MZFZ3

$95 \quad \mathrm{MZFZ} 4$

$96 \quad$ MZFZ5

97 MZFM

98 MZFMI

99 MZFM2

$100 \quad$ MZFM3

101 MZFM4

102 MZFM5

103 CGFS

104 CGESI

105 CGFS2

106 CGFS3

107 CGFS4

108 CGFS5

109 CGFZ

$110 \quad$ CGEZ1

111 CGEZ2

112 CGFZ3

113 CGFZ4

114 CGFZ5

115 CGFM

116 CGFM

117 CGFM2

118 CGFM3

119 CGFM4

120 CGFM5

121 MZCFZ

122 MZCFZ1

123 MZCFZ2

$124 \quad \mathrm{MZCFZ} 3$

$125 \mathrm{MZCEZ4}$

$126 \quad \mathrm{MZCFZ} 5$

$127 \quad$ MZCFM

Frozen Merluza Production

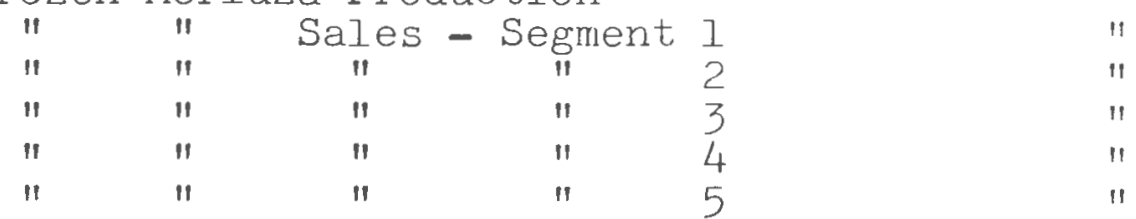

Merluza Fish Meal Production

\begin{tabular}{|c|c|c|c|c|}
\hline$"$ & $" 1$ & Sales & - Segment & 1 \\
\hline 11 & 11 & 11 & $" 1$ & 2 \\
\hline$"$ & "1 & " & $" 1$ & 3 \\
\hline " & $" 1$ & 11 & $" 1$ & 4 \\
\hline " & $" 1$ & $" 1$ & $" 1$ & 5 \\
\hline
\end{tabular}

Fresh Congrio Production

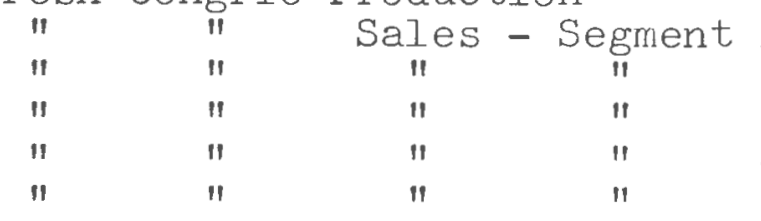

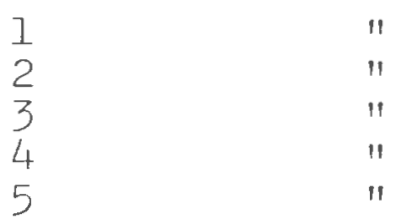

Frozen Congrio lroduction

\begin{tabular}{|c|c|c|c|c|c|}
\hline $1 "$ & & Sales & - Segment & 1 & $"$ \\
\hline 11 & $\|$ & 11 & 11 & 2 & $" 1$ \\
\hline " & $"$ & $" 1$ & 11 & 3 & $" 1$ \\
\hline 11 & II & 11 & $" 1$ & 4 & $" 1$ \\
\hline " & " & 11 & " & 5 & 11 \\
\hline
\end{tabular}

Congrio Fish Meal Production

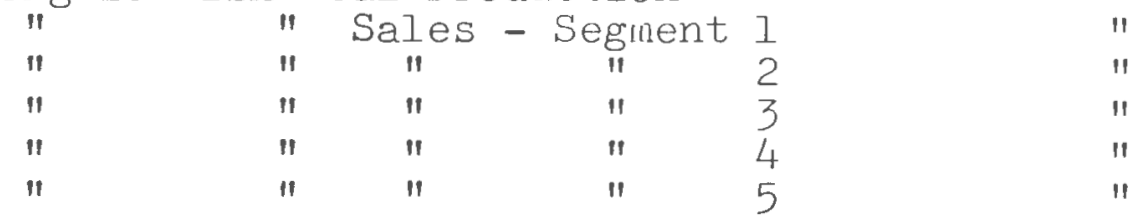

Frozen Merluza de Cola Production

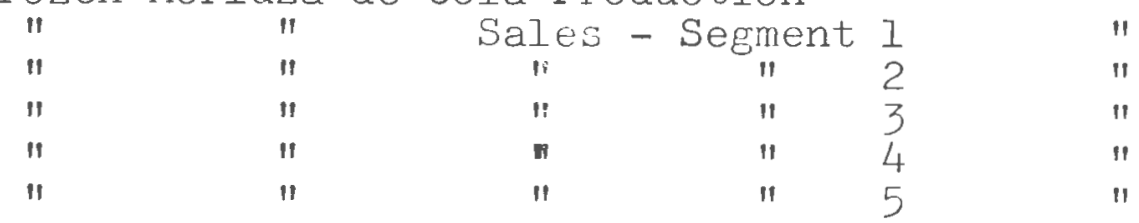

128 MZOFM

129 MZCFM2

$130 \quad$ MZCEM3

131 MZCFM4

132 MZCFM5

Merluza de Cola Fish Meal Production

\begin{tabular}{|c|c|c|c|c|}
\hline 11 & $" 1$ & Sales & - Segment & 1 \\
\hline$" 1$ & $" 1$ & 11 & $" 1$ & 2 \\
\hline$"$ & $n$ & 11 & $" 1$ & 3 \\
\hline " & 11 & $" 1$ & $" 1$ & 4 \\
\hline if & $"$ & 11 & "1 & [ \\
\hline
\end{tabular}


Appendix $\mathrm{C}-($ Cont.)

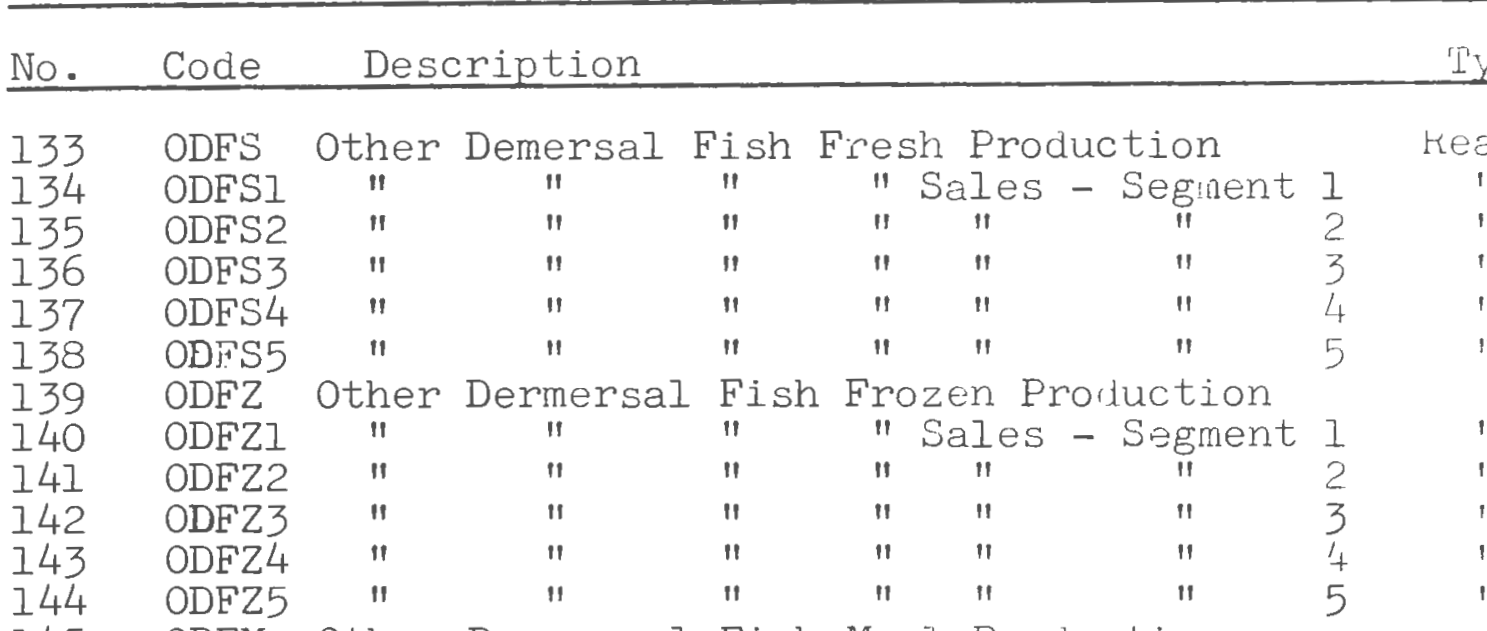

145

146

147

ODFM

Other Dermersal Fish Meal Production

148

ODFMI

ODFM2

149

ODFM3

150

ODFI4

"

"1
$" 1$
"

$\begin{array}{lcc}" & \text { Sales } & \text { " Segment } \\ " & " 1 & " 1 \\ " & " 1 & " 1 \\ " & " 1 & \end{array}$

1
2
3
4
5

151

ODFM5

Iype

152

153

154

FSHPK

Fresh Fish Production Capacity Availuble

Keal

FZPK Frozen Fish Production Capacity Available

II

11

II

11

155

156

CANPK

Canned Fish Production

Capacity Available

FMPK Fish Meal Production Capacity Available

ANAV Anchoveta Available

157

JUSAV Jurel Sierra Available

158

SARAV Sardina Available

159

AGAV Agujilla Available

160

OPAV Other Pelagic Fish Available

161

162

MEAV

Merluza Available

CGAV Congrio Available

163

MZCAV

Merluza de Cola Available

ODAV Other Dermersal Fish Available

164

FNANON Canned Anchoveta Net Rorexie Fun ti...:

165

GDANON Canned Anchoveta Net Revemue dixiliny

166

FNANFM Anchoveta Fish Meal Net Revenue Functionil

167

GDANFM Anchoveta Fish Meal Net Revenue Auxiliary

168

FNJUSFS Fresh Jurel-Sierra Net Revenue Functional

169

GDJUSFS Fresh Jurel-Sierra Net Revenue Auxiliary

170

FNJUSFZ Frozen Jurel-Sierra Net Revenue Functional

171

172

GDJUSFZ FrC

.173

FNJUSCN Canned Jurel-Sierra Net Revenue Functional
GDJUSCN Canned Jurel-Sierra Net Revenue Auxiliary

Canned Jurel-Sien

Net Revenue Auxiliary

174

FNJUSFM Jurel Sierra Fish Meal Net Revenue Functional"

175

GDJUSFM Jurel Sierra Fish Meal Net Revenue Auxiliary " 
Appendix C- (Cont.)

No. Code

176 FNSARFS

177 GDSARFS

178 FNSARCN

179 GDSARCN

180 FNSARFM

181 GDSARFM

182 FNAGCN

183 GDAGCN

184 FNAGFM

185 GDAGFM

186 FNOPES

187 GDOPFS

188 FNOPCN

189 GDOPCN

190 FNOPFM

191 GDOPFM

192 FNMZFS

193 GDMZFS

194 FNMZFZ

195 GDMZFZ

196 FNMZFM

197 GDMZFM

198 FNCGFS

199 GDCGES

200 FNCGF'

201 GDCGFZ

202 FNCGFM

203 GDCGFM

204 FNMCF'

205 GDMCEZ

206 FNMCF'M

207 GDMCFM

208 FNODFS

209 GDODFS

210 FNODFZ

211 GDODFZ

212 FNODFM

213 GDODEM
Description

Fresh Sardina Net Revenue Functional

Fresh Sardina Net Revenue Auxiliary

Canned Sardina Net Revenue Functional

Canned Sardina Net Revenue Auxiliary

Sardina FishmMeal Net Revenue Functional

Sardina Fish Meal Net Revenue Auxiliary

Canned Agujilla Net Revenue Functional

Canned Agujilla Net Revenue Auxiliary

Agujilla Fish Meal Net Revenue Functional

Agujilla Fish Meal Net Revenue Auxiliary

Other Pelagic Fish Net Revenue Functional

Other Pelagic Fish Net Revenue Auxiliary

Other Pelagic Fish Net Revenue Functional

Other Pelagic Fish Net Revenue Auxiliary

Other Pelagic Fish Net Revenue Functional

Other Pelagic Fish Net Revenue Auxiliary

Fresh Merluza Net Revenues Functional

Fresh Merluza Net Revenues Auxiliary

Frozen Merluza Net Revenue Functional

Frozen Merluza Net Revenue Auxiliary

Merluza Fish Meal Net Revenue Functional

Merluza Fish Meal Net Revenue Auxiliary

Fresh Congrio Net Revenue Functional

Fresh Congrio Net Revenue Auxiliary

Frozen Congrio Net Revenue Functional

Frozen Congrio Net Revenue Auxiliary

Congrio Fish Meal Net Revenue Functional

Congrio Fish Meal Net Revenue Auxiliary

Frozen Merluza de Cola Net Revenue Functional "

Frozen Merluza de Cola Net Revenue Auxiliary "

Merluza de Cola Fish Meal Net Revenue Functional "

Merluza de Cola Fish Meal Net Revenue Auxiliary "

Other Dermersal Fresh Fish Net Revenue Functional"

Other Dermersal Fresh Fish Net Revenue Auxiliary "

Other Dermersal Frozen Fish Net Revenue

Fuctional

Other Dermersal Frozen Fish Net Revenue Auxiliary

11

II

Other Dermersal Fish Meal Net Revenue

Functional

II

Other Dermersal Fish Meal Net Revenue

Auxiliary
II

11

II

"

"

4 , 11 11 11

11

II

II

II

"I

11

II

11

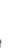


Appeniz D- Total Net Rovenue (in US $\$ \times 10^{3}$ ) and Associated Ouputs (in MT/Yr) for Zonal Production of Selected Fishery Commodities

Zone 1

\begin{tabular}{|c|c|c|c|c|c|c|}
\hline Commodity & & Segment 1 & Segment, 2 & Segment 3 & Segment 4 & Segment 5 \\
\hline $\begin{array}{l}\text { Achoveta } \\
\text { Canned }\end{array}$ & $\underset{Q}{T N R}$ & $\begin{array}{l}1,104 \\
3,000\end{array}$ & $\begin{array}{r}960 \\
6,000\end{array}$ & $\begin{array}{r}-2,340 \\
9,000\end{array}$ & $\begin{array}{l}-8,160 \\
12,000\end{array}$ & $\begin{array}{r}-16,500 \\
15,000\end{array}$ \\
\hline $\begin{array}{l}\text { Anchoveta } \\
\text { Fish Meal \& } \text { Qil }\end{array}$ & $\underset{Q}{\text { TNR }}$ & $\begin{array}{l}6,150 \\
5,000\end{array}$ & $\begin{array}{r}12,300 \\
100,000\end{array}$ & $\begin{array}{r}18,450 \\
150,000\end{array}$ & $\begin{array}{r}24,600 \\
200,000\end{array}$ & $\begin{array}{r}30,750 \\
250,000\end{array}$ \\
\hline $\begin{array}{l}\text { Jurel } \\
\text { Fresh }\end{array}$ & $\underset{Q}{T N R}$ & 1,000 & $\begin{array}{r}-200 \\
2,000\end{array}$ & $\begin{array}{r}-240 \\
3,000\end{array}$ & $\begin{array}{r}-640 \\
4,000\end{array}$ & $\begin{array}{r}-950 \\
5,000\end{array}$ \\
\hline $\begin{array}{l}\text { Jurel } \\
\text { Frozen }\end{array}$ & $\begin{array}{c}\text { TNR } \\
Q\end{array}$ & 5,000 & $\begin{array}{r}20 \\
10,000\end{array}$ & 15,000 & $\begin{array}{r}40 \\
20,000\end{array}$ & $\begin{array}{r}60 \\
25,000\end{array}$ \\
\hline $\begin{array}{l}\text { Jurel } \\
\text { Canned }\end{array}$ & $\begin{array}{c}\text { TNR } \\
Q\end{array}$ & $\begin{array}{l}1,104 \\
3,000\end{array}$ & $\begin{array}{r}960 \\
6,000\end{array}$ & $\begin{array}{r}-2,340 \\
9,000\end{array}$ & $\begin{array}{l}-8,160 \\
12,000\end{array}$ & $\begin{array}{l}16,500 \\
15,000\end{array}$ \\
\hline $\begin{array}{l}\text { Jurel } \\
\text { Fish Meal \& Oil }\end{array}$ & $\underset{Q}{\mathrm{TNR}}$ & $\begin{array}{r}1,230 \\
10,000\end{array}$ & $\begin{array}{r}2,460 \\
20,000\end{array}$ & $\begin{array}{r}3,690 \\
30,000\end{array}$ & $\begin{array}{r}4,920 \\
40,000\end{array}$ & $\begin{array}{r}6,150 \\
60,000\end{array}$ \\
\hline $\begin{array}{l}\text { Sardina } \\
\text { Fresh }\end{array}$ & $\underset{Q}{\mathrm{TNR}}$ & 1,000 & 2,000 & $\begin{array}{r}-150 \\
3,000\end{array}$ & $\begin{array}{r}-200 \\
4,000\end{array}$ & $\begin{array}{r}-250 \\
5,000\end{array}$ \\
\hline $\begin{array}{l}\text { Sardina } \\
\text { Canned }\end{array}$ & $\underset{Q}{T N R}$ & $\begin{array}{l}1,104 \\
3,000\end{array}$ & $\begin{array}{r}960 \\
6,000\end{array}$ & $\begin{array}{r}-2,340 \\
9,000\end{array}$ & $\begin{array}{l}-8,160 \\
12,000\end{array}$ & $\begin{array}{r}-16,500 \\
15,000\end{array}$ \\
\hline $\begin{array}{l}\text { Sardina } \\
\text { Fish Neal \& Oil }\end{array}$ & $\underset{Q}{T N R}$ & $\begin{array}{r}1,230 \\
10,000\end{array}$ & $\begin{array}{r}2,460 \\
20,000\end{array}$ & $\begin{array}{r}5,690 \\
30,000\end{array}$ & $\begin{array}{r}4,920 \\
40,000\end{array}$ & $\begin{array}{r}0,150 \\
50,000\end{array}$ \\
\hline Agujilla & TNR & 1,140 & 960 & $-2,340$ & $-3,160$ & $-10,500$ \\
\hline Canned & $Q$ & 3,000 & 6,000 & 9,000 & 12,000 & 15,000 \\
\hline
\end{tabular}




\begin{tabular}{|c|c|c|c|c|c|c|}
\hline Commodity & & Segne:- $\quad 1$ & Segment 2 & Segment 3 & Segment 4 & Segment 5 \\
\hline $\begin{array}{l}\text { Agujilla } \\
\text { Fish Meal \& Oil }\end{array}$ & $\begin{array}{c}\text { TNR } \\
Q\end{array}$ & $\begin{array}{r}1,230 \\
10,000\end{array}$ & $\begin{array}{r}2,460 \\
20,000\end{array}$ & $\begin{array}{r}3,690 \\
30,000\end{array}$ & $\begin{array}{r}4,920 \\
40,000\end{array}$ & $\begin{array}{r}6,150 \\
50,000\end{array}$ \\
\hline $\begin{array}{l}\text { Other Pelagic } \\
\text { Fresh }\end{array}$ & $\begin{array}{c}\text { TNR } \\
Q\end{array}$ & $\begin{array}{r}36 \\
3,000\end{array}$ & $\begin{array}{r}72 \\
6,000\end{array}$ & $\begin{array}{r}108 \\
9,000\end{array}$ & $\begin{array}{r}144 \\
12,000\end{array}$ & $\begin{array}{r}180 \\
15,000\end{array}$ \\
\hline $\begin{array}{l}\text { Other Pelagic } \\
\text { Canned }\end{array}$ & $\underset{Q}{T N R}$ & $\begin{array}{l}1,104 \\
3,000\end{array}$ & $\begin{array}{r}960 \\
6,000\end{array}$ & $\begin{array}{r}-2,340 \\
9,000\end{array}$ & $\begin{array}{l}-8,160 \\
12,000\end{array}$ & $\begin{array}{r}-16,500 \\
15,000\end{array}$ \\
\hline $\begin{array}{l}\text { Other Pelagic } \\
\text { Fish Meal \& Oil }\end{array}$ & $\begin{array}{c}\text { TNR } \\
Q\end{array}$ & $\begin{array}{r}1,230 \\
10,000\end{array}$ & $\begin{array}{r}2,460 \\
20,000\end{array}$ & $\begin{array}{r}3,690 \\
30,000\end{array}$ & $\begin{array}{r}4,920 \\
40,000\end{array}$ & $\begin{array}{r}6,150 \\
50,000\end{array}$ \\
\hline $\begin{array}{l}\text { Merluza } \\
\text { Fresh }\end{array}$ & $\begin{array}{c}\text { TNR } \\
Q\end{array}$ & 10,000 & $\begin{array}{c}0 \\
20,000\end{array}$ & 30,000 & $\begin{array}{c}0 \\
40,000\end{array}$ & $\begin{array}{c}0 \\
50,000\end{array}$ \\
\hline $\begin{array}{l}\text { Merluza } \\
\text { Frozen }\end{array}$ & $\underset{Q}{T N R}$ & 4,000 & $8, \stackrel{0}{0}$ & 12,000 & 16,000 & $20, \stackrel{0}{0} 000$ \\
\hline $\begin{array}{l}\text { Merluza } \\
\text { Fish Meal \& Oil }\end{array}$ & $\begin{array}{c}\text { TNR } \\
Q\end{array}$ & $\begin{array}{r}1,230 \\
10,000\end{array}$ & $\begin{array}{r}2,460 \\
20,000\end{array}$ & $\begin{array}{r}3,690 \\
30,000\end{array}$ & $\begin{array}{r}4,920 \\
40,000\end{array}$ & $\begin{array}{r}6,150 \\
50,000\end{array}$ \\
\hline $\begin{array}{l}\text { Congrio } \\
\text { Fresh }\end{array}$ & $\stackrel{+N R}{Q}$ & $\begin{array}{r}188 \\
1,500\end{array}$ & $\begin{array}{r}306 \\
1,000\end{array}$ & $\begin{array}{r}354 \\
1,500\end{array}$ & $\begin{array}{r}332 \\
2,000\end{array}$ & $\begin{array}{r}240 \\
2,500\end{array}$ \\
\hline $\begin{array}{l}\text { Congrio } \\
\text { Frozen }\end{array}$ & $\begin{array}{c}\text { TNR } \\
Q\end{array}$ & $\begin{array}{r}68 \\
400\end{array}$ & $\begin{array}{l}136 \\
800\end{array}$ & $\begin{array}{r}204 \\
1,200\end{array}$ & $\begin{array}{r}272 \\
1,600\end{array}$ & $\begin{array}{r}340 \\
2,000\end{array}$ \\
\hline $\begin{array}{l}\text { Congrio } \\
\text { Fish Meal \& Oil }\end{array}$ & $\begin{array}{c}\text { TNR } \\
Q\end{array}$ & $\begin{array}{r}1,230 \\
10,000\end{array}$ & $\begin{array}{r}2,460 \\
20,000\end{array}$ & $\begin{array}{r}5,690 \\
30,000\end{array}$ & $\begin{array}{r}4,920 \\
40,000\end{array}$ & $\begin{array}{r}6,150 \\
50,000\end{array}$ \\
\hline
\end{tabular}


Appendix D (Cont.)

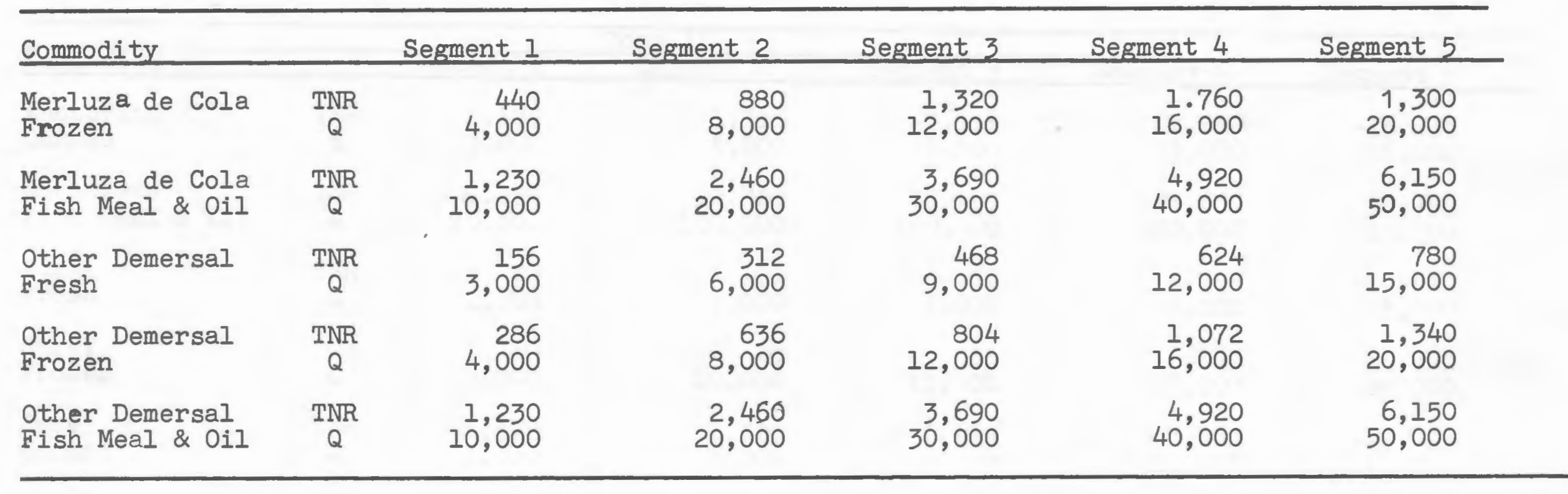


Arreniz: = -Total Net Revenue (in US $\$ \mathrm{x}$ 103) and Associated Outputs (NT/yr) for Zonal Production of Selected Fishery Commodities

\begin{tabular}{|c|c|c|c|c|c|c|}
\hline \multicolumn{7}{|c|}{ Zone II } \\
\hline Commodity & & Segment I & Segment 2 & Segment 3 & Segment 4 & Segment 5 \\
\hline $\begin{array}{l}\text { Anchoveta } \\
\text { Canned }\end{array}$ & $\underset{Q}{T N R}$ & $\begin{array}{l}1,179 \\
3,000\end{array}$ & $\begin{array}{l}1,110 \\
6,000\end{array}$ & $\begin{array}{r}-8,115 \\
9,000\end{array}$ & $\begin{array}{l}-7,860 \\
12,000\end{array}$ & $\begin{array}{r}-16,125 \\
15,000\end{array}$ \\
\hline $\begin{array}{l}\text { Anchoveta } \\
\text { Fish Mieal \& Oil }\end{array}$ & $\underset{Q}{\mathrm{TNR}}$ & $\begin{array}{r}6,150 \\
50,000\end{array}$ & $\begin{array}{r}12,300 \\
100,000\end{array}$ & $\begin{array}{r}18,400 \\
150,000\end{array}$ & $\begin{array}{r}24,600 \\
200,000\end{array}$ & $\begin{array}{r}30,750 \\
250,000\end{array}$ \\
\hline $\begin{array}{l}\text { Jurel } \\
\text { Fresh }\end{array}$ & $\underset{Q}{T N R}$ & 1,000 & 2,000 & $\begin{array}{r}-126 \\
3,000\end{array}$ & $\begin{array}{r}-288 \\
4,000\end{array}$ & $\begin{array}{r}-510 \\
5,000\end{array}$ \\
\hline $\begin{array}{l}\text { Jurel } \\
\text { Frozen }\end{array}$ & $\underset{Q}{T N R}$ & $\begin{array}{r}10 \\
5,000\end{array}$ & 10,000 & 15,000 & $\begin{array}{r}40 \\
20,000\end{array}$ & 25,000 \\
\hline $\begin{array}{l}\text { Jurel } \\
\text { Canned }\end{array}$ & $\begin{array}{c}\text { TNR } \\
Q\end{array}$ & $\begin{array}{l}1,179 \\
3,000\end{array}$ & $\begin{array}{l}1,110 \\
6,000\end{array}$ & $\begin{array}{r}-2,115 \\
9,000\end{array}$ & $\begin{array}{l}-7,860 \\
12,000\end{array}$ & $\begin{array}{r}-16,125 \\
15,000\end{array}$ \\
\hline $\begin{array}{l}\text { Jurel } \\
\text { Fish Meal \& Oil }\end{array}$ & $\underset{Q}{T N R}$ & $\begin{array}{r}1,230 \\
10,000\end{array}$ & $\begin{array}{r}2,460 \\
20,000\end{array}$ & $\begin{array}{r}3,690 \\
30,000\end{array}$ & $\begin{array}{r}4.920 \\
40,000\end{array}$ & $\begin{array}{r}6,150 \\
60,000\end{array}$ \\
\hline $\begin{array}{l}\text { Sardina } \\
\text { Fresh }\end{array}$ & $\begin{array}{c}\text { TNR } \\
Q\end{array}$ & $\begin{array}{r}38 \\
1,000\end{array}$ & $\begin{array}{r}76 \\
2,000\end{array}$ & $\begin{array}{r}114 \\
3,000\end{array}$ & $\begin{array}{r}152 \\
4,000\end{array}$ & $\begin{array}{r}190 \\
5,000\end{array}$ \\
\hline $\begin{array}{l}\text { Sardina } \\
\text { Canned }\end{array}$ & $\underset{Q}{T N R}$ & $\begin{array}{l}1,179 \\
3,000\end{array}$ & $\begin{array}{l}1,110 \\
6,000\end{array}$ & $\begin{array}{r}-2,115 \\
9,000\end{array}$ & $\begin{array}{l}-7,860 \\
12,000\end{array}$ & $\begin{array}{r}-16,125 \\
15,000\end{array}$ \\
\hline $\begin{array}{l}\text { Sardina } \\
\text { Fish Meal \& Oil }\end{array}$ & $\begin{array}{c}\text { TNR } \\
Q\end{array}$ & $\begin{array}{r}1,230 \\
10,000\end{array}$ & $\begin{array}{r}2,460 \\
20,000\end{array}$ & $\begin{array}{r}3,690 \\
30,000\end{array}$ & $\begin{array}{r}4,920 \\
40,000\end{array}$ & $\begin{array}{r}6,150 \\
50,000\end{array}$ \\
\hline
\end{tabular}




\section{ipperzix D (Cont.)}

\begin{tabular}{|c|c|c|c|c|c|c|}
\hline Commodity & & gment 1 & Segment 2 & Segment 3 & Segment 4 & Segment \\
\hline $\begin{array}{l}\text { Agujilla } \\
\text { Canned }\end{array}$ & $\underset{Q}{T N R}$ & $\begin{array}{l}1,179 \\
3,000\end{array}$ & $\begin{array}{l}1,110 \\
6,000\end{array}$ & $\begin{array}{r}-2,115 \\
9,000\end{array}$ & $\begin{array}{l}-7,860 \\
12,000\end{array}$ & $\begin{array}{r}-16,125 \\
15,000\end{array}$ \\
\hline $\begin{array}{l}\text { Agujilla } \\
\text { Fish Meal \& Oil }\end{array}$ & $\underset{Q}{T N R}$ & $\begin{array}{r}1,230 \\
10,000\end{array}$ & $\begin{array}{r}2,460 \\
20,000\end{array}$ & $\begin{array}{r}3,690 \\
30,000\end{array}$ & $\begin{array}{r}4.920 \\
40,000\end{array}$ & $\begin{array}{r}6,150 \\
50,000\end{array}$ \\
\hline $\begin{array}{l}\text { Other Pelagic } \\
\text { Fresh }\end{array}$ & $\underset{Q}{T N R}$ & $\begin{array}{r}36 \\
3,000\end{array}$ & $\begin{array}{r}72 \\
6,000\end{array}$ & $\begin{array}{r}108 \\
9,000\end{array}$ & $\begin{array}{r}144 \\
12,000\end{array}$ & $\begin{array}{r}180 \\
15,000\end{array}$ \\
\hline $\begin{array}{l}\text { Other Pelagic } \\
\text { Canned }\end{array}$ & $\begin{array}{c}\text { TNR } \\
Q\end{array}$ & $\begin{array}{l}1,203 \\
3,000\end{array}$ & $\begin{array}{l}1,158 \\
6,000\end{array}$ & $\begin{array}{r}-2,043 \\
9,000\end{array}$ & $\begin{array}{l}-7,764 \\
12,000\end{array}$ & $\begin{array}{r}-16,005 \\
15,000\end{array}$ \\
\hline $\begin{array}{l}\text { Other Pelagic } \\
\text { Fish Meal \& Oil }\end{array}$ & $\underset{Q}{T N R}$ & $\begin{array}{r}1,230 \\
10,000\end{array}$ & $\begin{array}{r}2,460 \\
20,000\end{array}$ & $\begin{array}{r}3,690 \\
30,000\end{array}$ & $\begin{array}{r}4,920 \\
40,000\end{array}$ & $\begin{array}{r}6,150 \\
50,000\end{array}$ \\
\hline $\begin{array}{l}\text { Merluza } \\
\text { Fresh }\end{array}$ & $\begin{array}{c}\text { TNR } \\
Q\end{array}$ & $\begin{array}{r}45 \\
10,000\end{array}$ & $\begin{array}{r}30 \\
20,000\end{array}$ & $\begin{array}{r}-45 \\
30,000\end{array}$ & $\begin{array}{r}-180 \\
40,000\end{array}$ & $\begin{array}{r}-375 \\
50,000\end{array}$ \\
\hline $\begin{array}{l}\text { Merluza } \\
\text { Frozen }\end{array}$ & $\underset{Q}{T N R}$ & $\begin{array}{r}668 \\
4,000\end{array}$ & $\begin{array}{l}1,336 \\
8,000\end{array}$ & $\begin{array}{r}2,004 \\
12,000\end{array}$ & $\begin{array}{r}2,672 \\
16,000\end{array}$ & $\begin{array}{r}3,340 \\
20,000\end{array}$ \\
\hline $\begin{array}{l}\text { Merluza } \\
\text { Fish Meal \& Oil }\end{array}$ & $\underset{Q}{T N R}$ & $\begin{array}{r}1,230 \\
10,000\end{array}$ & $\begin{array}{r}2,460 \\
20,000\end{array}$ & $\begin{array}{r}3,690 \\
30,000\end{array}$ & $\begin{array}{r}4,920 \\
40,000\end{array}$ & $\begin{array}{r}6,150 \\
50,000\end{array}$ \\
\hline $\begin{array}{l}\text { Congrio } \\
\text { Fresh }\end{array}$ & $\begin{array}{c}\text { TNR } \\
Q\end{array}$ & $\begin{array}{l}232 \\
500\end{array}$ & $\begin{array}{r}394 \\
1,000\end{array}$ & $\begin{array}{r}486 \\
1,500\end{array}$ & $\begin{array}{r}508 \\
2,000\end{array}$ & $\begin{array}{r}460 \\
2,500\end{array}$ \\
\hline $\begin{array}{l}\text { Congrio } \\
\text { Frozen }\end{array}$ & $\underset{Q}{\mathrm{TNR}}$ & $\begin{array}{r}68 \\
400\end{array}$ & $\begin{array}{l}136 \\
300\end{array}$ & $\begin{array}{r}204 \\
1,200\end{array}$ & $\begin{array}{r}272 \\
1,600\end{array}$ & $\begin{array}{r}3,30 \\
2,000\end{array}$ \\
\hline $\begin{array}{l}\text { Congrio } \\
\text { Fish Meal \& Oil }\end{array}$ & $\begin{array}{c}\text { TINR } \\
Q\end{array}$ & 1,230 & 2,460 & 3,090 & 4,920 & 0,150 \\
\hline
\end{tabular}


Appendix D (Cont.)

\begin{tabular}{|c|c|c|c|c|c|c|}
\hline Commodity & & Segment 1 , & Segment 2 & Segment 3 & Segment 4 & Segment 5 \\
\hline $\begin{array}{l}\text { Merluza de Cola } \\
\text { Frozen }\end{array}$ & $\begin{array}{c}\mathrm{TNR} \\
\mathrm{Q}\end{array}$ & $\begin{array}{r}440 \\
4,000\end{array}$ & $\begin{array}{r}880 \\
8,000\end{array}$ & $\begin{array}{r}1,320 \\
12,000\end{array}$ & $\begin{array}{r}1,760 \\
16,000\end{array}$ & $\begin{array}{r}2,200 \\
20,000\end{array}$ \\
\hline $\begin{array}{l}\text { Merluza de Cola } \\
\text { Fish Meal \& Oil }\end{array}$ & TNR & $\begin{array}{r}1,230 \\
10,000\end{array}$ & $\begin{array}{r}2,460 \\
20,000\end{array}$ & $\begin{array}{r}3,690 \\
30,000\end{array}$ & $\begin{array}{r}4,920 \\
40,000\end{array}$ & $\begin{array}{r}6,150 \\
50,000\end{array}$ \\
\hline $\begin{array}{l}\text { Other Demersal } \\
\text { Fresh }\end{array}$ & $\begin{array}{c}\text { TNR } \\
Q\end{array}$ & $\begin{array}{r}420 \\
3,000\end{array}$ & $\begin{array}{r}840 \\
6,000\end{array}$ & $\frac{1,260}{9,000}$ & $\begin{array}{r}1,680 \\
12,000\end{array}$ & $\begin{array}{r}2,100 \\
15,000\end{array}$ \\
\hline $\begin{array}{l}\text { Other Demersal } \\
\text { Frozen }\end{array}$ & $\begin{array}{c}\text { TNR } \\
Q\end{array}$ & $\begin{array}{r}286 \\
4,000\end{array}$ & $\begin{array}{r}536 \\
8,000\end{array}$ & $\begin{array}{r}804 \\
12,000\end{array}$ & $\begin{array}{r}1,072 \\
16,000\end{array}$ & $\begin{array}{r}1,340 \\
20,000\end{array}$ \\
\hline $\begin{array}{l}\text { Other Demersal } \\
\text { Fish Meal \& Oil }\end{array}$ & $\begin{array}{c}\text { TNR } \\
Q\end{array}$ & $\begin{array}{r}1,230 \\
10,000\end{array}$ & $\begin{array}{r}2,460 \\
20,000\end{array}$ & $\begin{array}{r}3,690 \\
30,000\end{array}$ & $\begin{array}{r}4,920 \\
40,000\end{array}$ & $\begin{array}{r}6,150 \\
50,000\end{array}$ \\
\hline
\end{tabular}


Appenaix J . Total Net Revenue (in US $\$ \times 10^{3}$ ) and Associated Outputs (in MT/Yr) for Zonal Production of Selected Fishery Commodities

\begin{tabular}{|c|c|c|c|c|c|c|}
\hline & & & Zone III & & & \\
\hline Commodity & & Segment I & Segment 2 & Segment 3 & Segment 4 & Segment 5 \\
\hline $\begin{array}{l}\text { Anchoveta } \\
\text { Canned }\end{array}$ & $\begin{array}{c}\mathrm{TNR} \\
\mathrm{Q}\end{array}$ & $\begin{array}{l}1,203 \\
3,000\end{array}$ & $\begin{array}{l}1,158 \\
6,000\end{array}$ & $\begin{array}{r}-2,043 \\
9,000\end{array}$ & $\begin{array}{l}-7,764 \\
12,000\end{array}$ & $\begin{array}{r}-16,005 \\
15,000\end{array}$ \\
\hline $\begin{array}{l}\text { Anchoveta } \\
\text { Fish Meal \& Oil }\end{array}$ & $\begin{array}{c}\mathrm{TNR} \\
\mathrm{Q}\end{array}$ & $\begin{array}{r}6,150 \\
50,000\end{array}$ & $\begin{array}{r}12,300 \\
100,000\end{array}$ & $\begin{array}{r}18,450 \\
150,000\end{array}$ & $\begin{array}{r}24,600 \\
200,000\end{array}$ & $\begin{array}{r}30,750 \\
250,000\end{array}$ \\
\hline $\begin{array}{l}\text { Jurel } \\
\text { Fresh }\end{array}$ & $\begin{array}{c}\text { TNR } \\
Q\end{array}$ & $\begin{array}{r}40 \\
1,000\end{array}$ & $\begin{array}{r}20 \\
2,000\end{array}$ & $\begin{array}{r}-60 \\
3,000\end{array}$ & $\begin{array}{r}-200 \\
4,000\end{array}$ & $\begin{array}{r}-400 \\
5,000\end{array}$ \\
\hline $\begin{array}{l}\text { Jurel } \\
\text { Frozen }\end{array}$ & $\begin{array}{c}\text { TNR } \\
Q\end{array}$ & $\begin{array}{r}10 \\
5,000\end{array}$ & $\begin{array}{r}20 \\
10,000\end{array}$ & $\begin{array}{r}30 \\
15,000\end{array}$ & $\begin{array}{r}40 \\
20,000\end{array}$ & $\begin{array}{r}50 \\
25,000\end{array}$ \\
\hline $\begin{array}{l}\text { Jurel } \\
\text { Canned }\end{array}$ & $\begin{array}{c}\text { TNR } \\
Q\end{array}$ & $\begin{array}{l}1,203 \\
3,000\end{array}$ & $\begin{array}{l}1,158 \\
6,000\end{array}$ & $\begin{array}{r}-2,043 \\
9,000\end{array}$ & $\begin{array}{l}-7,764 \\
12,000\end{array}$ & $\begin{array}{r}-16,005 \\
15,000\end{array}$ \\
\hline $\begin{array}{l}\text { Jurel } \\
\text { Fish Meal \& Oil }\end{array}$ & $\begin{array}{c}\text { TNR } \\
Q\end{array}$ & $\begin{array}{r}1,230 \\
10,000\end{array}$ & $\begin{array}{r}2,460 \\
20,000\end{array}$ & $\begin{array}{r}3,090 \\
30,000\end{array}$ & $\begin{array}{r}4,920 \\
40,000\end{array}$ & $\begin{array}{r}6,150 \\
50,000\end{array}$ \\
\hline $\begin{array}{l}\text { Sardina } \\
\text { Fresh }\end{array}$ & $\begin{array}{l}\text { TNR } \\
\mathrm{Q}\end{array}$ & $\begin{array}{r}60 \\
1,000\end{array}$ & $\begin{array}{r}120 \\
2,000\end{array}$ & $\begin{array}{r}180 \\
3,000\end{array}$ & $\begin{array}{r}240 \\
4,000\end{array}$ & $\begin{array}{r}300 \\
5,000\end{array}$ \\
\hline $\begin{array}{l}\text { Sardina } \\
\text { Canned }\end{array}$ & $\begin{array}{c}\text { TNR } \\
\mathrm{Q}\end{array}$ & $\begin{array}{l}1,203 \\
3,000\end{array}$ & $\begin{array}{l}1,158 \\
6,000\end{array}$ & $\begin{array}{r}-2,043 \\
9,000\end{array}$ & $\begin{array}{l}-7,764 \\
12,000\end{array}$ & $\begin{array}{r}-16,005 \\
15,000\end{array}$ \\
\hline $\begin{array}{l}\text { Sardina } \\
\text { Fish Meal \& Oil }\end{array}$ & $\begin{array}{c}\text { TNR } \\
Q\end{array}$ & $\begin{array}{r}1,230 \\
10,000\end{array}$ & $\begin{array}{r}2,460 \\
20,000\end{array}$ & $\begin{array}{r}3,690 \\
30,000\end{array}$ & $\begin{array}{r}4,920 \\
40,000\end{array}$ & $\begin{array}{r}6,150 \\
50,000\end{array}$ \\
\hline
\end{tabular}


Appendix $D$ (Cont.)

\begin{tabular}{|c|c|c|c|c|c|c|}
\hline Commodity & & Segment 1 & Segment 2 & Segment 3 & Segment 4 & Segment 5 \\
\hline $\begin{array}{l}\text { Agujilla } \\
\text { Canned }\end{array}$ & $\begin{array}{c}\mathrm{TNR} \\
\mathrm{Q}\end{array}$ & $\begin{array}{l}1,203 \\
3,000\end{array}$ & $\begin{array}{l}\frac{1}{6}, 158 \\
6,000\end{array}$ & $\begin{array}{r}-2,043 \\
9,000\end{array}$ & $\begin{array}{l}-7.764 \\
12,000\end{array}$ & $\begin{array}{r}-16,005 \\
15,000\end{array}$ \\
\hline $\begin{array}{l}\text { Other Pelagic } \\
\text { Fresh }\end{array}$ & $\begin{array}{c}\text { TNR } \\
Q\end{array}$ & $\begin{array}{r}366 \\
3,000\end{array}$ & $\begin{array}{r}732 \\
6,000\end{array}$ & $\begin{array}{l}1,098 \\
9,000\end{array}$ & $\begin{array}{r}1,464 \\
12,000\end{array}$ & $\begin{array}{r}1,830 \\
15,000\end{array}$ \\
\hline $\begin{array}{l}\text { Other Pelagic } \\
\text { Canned }\end{array}$ & $\begin{array}{c}\text { TNR } \\
Q\end{array}$ & $\begin{array}{l}1.203 \\
3,000\end{array}$ & $\begin{array}{l}1,158 \\
6,000\end{array}$ & $\begin{array}{r}-2,043 \\
9,000\end{array}$ & $\begin{array}{l}-7,764 \\
12,000\end{array}$ & $\begin{array}{r}-16,005 \\
15,000\end{array}$ \\
\hline $\begin{array}{l}\text { Other Pelagic } \\
\text { Fish Meal \& Oil }\end{array}$ & $\begin{array}{c}\text { TNR } \\
Q\end{array}$ & $\begin{array}{r}1,230 \\
10,000\end{array}$ & $\begin{array}{r}2,460 \\
20,000\end{array}$ & $\begin{array}{r}3,690 \\
30,000\end{array}$ & $\begin{array}{r}4,920 \\
40,000\end{array}$ & $\begin{array}{r}6,150 \\
50,000\end{array}$ \\
\hline $\begin{array}{l}\text { Merluza } \\
\text { Fresh }\end{array}$ & $\begin{array}{l}\text { TNR } \\
\mathrm{Q}\end{array}$ & $\begin{array}{r}67 \\
10,000\end{array}$ & $\begin{array}{r}74 \\
20,000\end{array}$ & 30,000 & 40,000 & $\begin{array}{r}-265 \\
50,000\end{array}$ \\
\hline $\begin{array}{l}\text { Merluza } \\
\text { Fish Meal \& Oil }\end{array}$ & $\begin{array}{l}\text { TNR } \\
Q\end{array}$ & $\begin{array}{r}1,230 \\
10,000\end{array}$ & $\begin{array}{r}2,460 \\
20,000\end{array}$ & $\begin{array}{r}3,690 \\
30,000\end{array}$ & $\begin{array}{r}4,920 \\
40,000\end{array}$ & $\begin{array}{r}6,150 \\
50,000\end{array}$ \\
\hline $\begin{array}{l}\text { Congrio } \\
\text { Fresh }\end{array}$ & $\begin{array}{c}\text { TNR } \\
Q\end{array}$ & $\begin{array}{l}248 \\
500\end{array}$ & $\begin{array}{r}426 \\
1,000\end{array}$ & $\begin{array}{r}534 \\
1,500\end{array}$ & $\begin{array}{r}572 \\
2,000\end{array}$ & $\begin{array}{r}540 \\
2,500\end{array}$ \\
\hline $\begin{array}{l}\text { Congrio } \\
\text { Frozen }\end{array}$ & $\begin{array}{c}\text { TNR } \\
Q\end{array}$ & $\begin{array}{l}618 \\
400\end{array}$ & $\begin{array}{l}136 \\
800\end{array}$ & $\begin{array}{r}204 \\
1,200\end{array}$ & $\begin{array}{r}272 \\
1,600\end{array}$ & $\begin{array}{r}340 \\
2,000\end{array}$ \\
\hline $\begin{array}{l}\text { Congrio } \\
\text { Fish Iveal \& Oil }\end{array}$ & $\begin{array}{c}\text { TNR } \\
Q\end{array}$ & $\begin{array}{r}1,230 \\
10,000\end{array}$ & $\begin{array}{r}2,460 \\
20,000\end{array}$ & $\begin{array}{r}5,600 \\
50,000\end{array}$ & $\begin{array}{l}4,020 \\
40,000\end{array}$ & 50,150 \\
\hline
\end{tabular}


Aprosity (Cont.)

\begin{tabular}{|c|c|c|c|c|c|c|}
\hline Commodity & & Segment I & Segment 2 & Segment 3 & Segment 4 & Segment 5 \\
\hline $\begin{array}{l}\text { Merluza de Cola } \\
\text { Frozen }\end{array}$ & $\underset{Q}{T N R}$ & $\begin{array}{r}400 \\
4,000\end{array}$ & $\begin{array}{r}880 \\
8,000\end{array}$ & $\begin{array}{r}1,320 \\
12,000\end{array}$ & $\begin{array}{r}1,760 \\
16,000\end{array}$ & $\begin{array}{r}2,200 \\
20,000\end{array}$ \\
\hline $\begin{array}{l}\text { Mierluza de Cola } \\
\text { Fish Meal \& Oil }\end{array}$ & $\begin{array}{c}\text { TNR } \\
Q\end{array}$ & $\begin{array}{r}1,230 \\
10,000\end{array}$ & $\begin{array}{r}2,460 \\
20,000\end{array}$ & $\begin{array}{r}3,690 \\
30,000\end{array}$ & $\begin{array}{r}4,920 \\
40,000\end{array}$ & $\begin{array}{r}6,150 \\
50,000\end{array}$ \\
\hline $\begin{array}{l}\text { Other Demersal } \\
\text { Fresh }\end{array}$ & $\begin{array}{c}\text { TNR } \\
Q\end{array}$ & $\begin{array}{r}486 \\
3,000\end{array}$ & $\begin{array}{r}972 \\
6,000\end{array}$ & $\begin{array}{l}1,458 \\
9,000\end{array}$ & $\begin{array}{r}1,944 \\
12,000\end{array}$ & $\begin{array}{r}2,430 \\
15,000\end{array}$ \\
\hline $\begin{array}{l}\text { Other Demersal } \\
\text { Frozen }\end{array}$ & $\begin{array}{c}\text { TNR } \\
Q\end{array}$ & $\begin{array}{r}286 \\
4,000\end{array}$ & $\begin{array}{r}536 \\
8,000\end{array}$ & $\begin{array}{r}804 \\
12,000\end{array}$ & $\begin{array}{r}1,072 \\
16,000\end{array}$ & $\begin{array}{r}1,340 \\
20,000\end{array}$ \\
\hline $\begin{array}{l}\text { Other Demersal } \\
\text { Fish Meal \& Oil }\end{array}$ & $\begin{array}{c}\text { TNR } \\
Q\end{array}$ & $\begin{array}{r}1,230 \\
10,000\end{array}$ & $\begin{array}{r}2,460 \\
20,000\end{array}$ & $\begin{array}{r}3,690 \\
30,000\end{array}$ & $\begin{array}{r}4,920 \\
40,000\end{array}$ & $\begin{array}{r}6,150 \\
50,000\end{array}$ \\
\hline
\end{tabular}




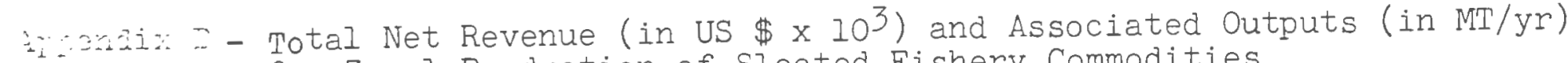 for Zonal Production of Slected Fishery Commodities}

\begin{tabular}{|c|c|c|c|c|c|c|}
\hline Commodity & & Segment I & $\begin{array}{l}\text { Zone IV } \\
\text { Segment } 2 \\
\end{array}$ & Segment 3 & Segment 4 & Segment 5 \\
\hline $\begin{array}{l}\text { Anchoveta } \\
\text { Canned }\end{array}$ & $\begin{array}{c}\text { TNR } \\
Q\end{array}$ & $\begin{array}{l}1,152 \\
3,000\end{array}$ & $\begin{array}{l}1,056 \\
6,000\end{array}$ & $\begin{array}{r}-2,196 \\
0,000\end{array}$ & $\begin{array}{l}-7,968 \\
12,000\end{array}$ & $\begin{array}{l}-16,260 \\
15,000\end{array}$ \\
\hline $\begin{array}{l}\text { Ancchoveta } \\
\text { Fish Meal \& Oil }\end{array}$ & $\begin{array}{c}\text { TNR } \\
Q\end{array}$ & $\begin{array}{r}6,150 \\
50,000\end{array}$ & $\begin{array}{r}12,300 \\
100,000\end{array}$ & $\begin{array}{r}18,450 \\
150,000\end{array}$ & $\begin{array}{r}24,600 \\
200,000\end{array}$ & $\begin{array}{r}30,750 \\
250,000\end{array}$ \\
\hline $\begin{array}{l}\text { Jurel } \\
\text { Fresh }\end{array}$ & $\begin{array}{c}\text { TNR } \\
Q\end{array}$ & $\begin{array}{r}-10 \\
1,000\end{array}$ & 2,000 & $\begin{array}{r}-210 \\
3,000\end{array}$ & $\begin{array}{r}-400 \\
4,000\end{array}$ & $\begin{array}{r}-650 \\
5,000\end{array}$ \\
\hline $\begin{array}{l}\text { Jurel } \\
\text { Frozen }\end{array}$ & $\begin{array}{c}\text { TNR } \\
Q\end{array}$ & $\begin{array}{r}10 \\
5,000\end{array}$ & $\begin{array}{r}20 \\
10,000\end{array}$ & $\begin{array}{r}30 \\
15,000\end{array}$ & $\begin{array}{r}40 \\
20,000\end{array}$ & $\begin{array}{r}50 \\
25,000\end{array}$ \\
\hline $\begin{array}{l}\text { Jurel } \\
\text { Canned }\end{array}$ & $\begin{array}{c}\text { TNR } \\
Q\end{array}$ & $\begin{array}{l}1,152 \\
3,000\end{array}$ & $\begin{array}{l}1,056 \\
6,000\end{array}$ & $\begin{array}{r}-2,196 \\
9,000\end{array}$ & $\begin{array}{l}-7,968 \\
12,000\end{array}$ & $\begin{array}{r}-16,260 \\
15,000\end{array}$ \\
\hline $\begin{array}{l}\text { Jurel } \\
\text { Fish Meal \& Oil }\end{array}$ & $\begin{array}{c}\text { TNR } \\
Q\end{array}$ & $\begin{array}{r}1,230 \\
10,000\end{array}$ & $\begin{array}{r}2,460 \\
20,000\end{array}$ & $\begin{array}{r}3,690 \\
30,000\end{array}$ & $\begin{array}{r}4,920 \\
40,000\end{array}$ & $\begin{array}{r}6,150 \\
50,000\end{array}$ \\
\hline $\begin{array}{l}\text { Sardina } \\
\text { Fresh }\end{array}$ & $\begin{array}{c}\text { TNR } \\
Q\end{array}$ & $\begin{array}{r}10 \\
1,000\end{array}$ & $\begin{array}{r}20 \\
2,000\end{array}$ & $\begin{array}{r}30 \\
3,000\end{array}$ & $\begin{array}{r}40 \\
4,000\end{array}$ & $\begin{array}{r}50 \\
5,000\end{array}$ \\
\hline $\begin{array}{l}\text { Sardina } \\
\text { Canned }\end{array}$ & $\underset{Q}{\mathrm{TNR}}$ & $\begin{array}{l}1,152 \\
3,000\end{array}$ & $\begin{array}{l}1,056 \\
6,000\end{array}$ & $\begin{array}{l}2,196 \\
9,000\end{array}$ & $\begin{array}{r}7.963 \\
12.000\end{array}$ & $\begin{array}{l}16,260 \\
15,000\end{array}$ \\
\hline $\begin{array}{l}\text { Sardina } \\
\text { Fish …al \& Oil }\end{array}$ & $\begin{array}{c}\text { TNR } \\
Q\end{array}$ & $\begin{array}{r}1,230 \\
10,000\end{array}$ & $\begin{array}{r}2,460 \\
20,000\end{array}$ & $\begin{array}{r}3,600 \\
53,200\end{array}$ & $\begin{array}{r}4,020 \\
+\quad, 000\end{array}$ & $5, \frac{150}{5,000}$ \\
\hline
\end{tabular}




$$
\text { inpendiz }=\text { - (Cont.) }
$$

\begin{tabular}{|c|c|c|c|c|c|c|}
\hline Commodity & & Segment I & Segment 2 & Segment 3 & Segment 4 & Segment 5 \\
\hline $\begin{array}{l}\text { Agujilla } \\
\text { Canned }\end{array}$ & $\begin{array}{c}\text { TNR } \\
Q\end{array}$ & $\begin{array}{l}1,152 \\
3,600\end{array}$ & $\begin{array}{l}1,056 \\
6,000\end{array}$ & $\begin{array}{r}-2,196 \\
9,000\end{array}$ & $\begin{array}{l}-7,968 \\
12,000\end{array}$ & $\begin{array}{l}16,260 \\
15,000\end{array}$ \\
\hline $\begin{array}{l}\text { Agujilla } \\
\text { Fish Meal \& Oil }\end{array}$ & $\begin{array}{c}\text { TNR } \\
Q\end{array}$ & $\begin{array}{r}1,230 \\
10,000\end{array}$ & $\begin{array}{r}2,460 \\
20,000\end{array}$ & $\begin{array}{r}3,690 \\
30,000\end{array}$ & $\begin{array}{r}4,920 \\
40,000\end{array}$ & $\begin{array}{r}6,150 \\
50,000\end{array}$ \\
\hline $\begin{array}{l}\text { Other Pelagic } \\
\text { Fresh }\end{array}$ & $\begin{array}{c}\mathrm{TNR} \\
\mathrm{Q}\end{array}$ & $\begin{array}{r}210 \\
3,000\end{array}$ & $\begin{array}{r}420 \\
6,000\end{array}$ & $\begin{array}{r}630 \\
9,000\end{array}$ & $\begin{array}{r}340 \\
12,000\end{array}$ & $\begin{array}{r}1,050 \\
15,000\end{array}$ \\
\hline $\begin{array}{l}\text { Other Pelagic } \\
\text { Canned }\end{array}$ & $\begin{array}{c}\text { PNR } \\
Q\end{array}$ & $\begin{array}{l}1,152 \\
3,000\end{array}$ & $\begin{array}{l}1,056 \\
6,000\end{array}$ & $\begin{array}{r}-2,196 \\
9,000\end{array}$ & $\begin{array}{l}-7,968 \\
12,000\end{array}$ & $\begin{array}{r}-16,260 \\
15,000\end{array}$ \\
\hline $\begin{array}{l}\text { Other Pelagic } \\
\text { Fish Meal \& Oil }\end{array}$ & $\begin{array}{c}\text { TNR } \\
Q\end{array}$ & $\begin{array}{r}1,230 \\
10,000\end{array}$ & $\begin{array}{r}2,460 \\
20,000\end{array}$ & $\begin{array}{r}3,690 \\
30,000\end{array}$ & $\begin{array}{r}4,920 \\
40,000\end{array}$ & $\begin{array}{r}6,150 \\
50,000\end{array}$ \\
\hline $\begin{array}{l}\text { Merluza } \\
\text { Fresh }\end{array}$ & $\begin{array}{c}\text { TNR } \\
\mathrm{Q}\end{array}$ & $\begin{array}{r}17 \\
10,000\end{array}$ & $\begin{array}{r}-26 \\
20,000\end{array}$ & $\begin{array}{r}-129 \\
30,000\end{array}$ & $\begin{array}{r}-292 \\
40,000\end{array}$ & $\begin{array}{r}-515 \\
50,000\end{array}$ \\
\hline $\begin{array}{l}\text { Merluza } \\
\text { Frozen }\end{array}$ & $\begin{array}{c}\text { TNR } \\
Q\end{array}$ & $\begin{array}{r}668 \\
4,000\end{array}$ & $\begin{array}{l}1,336 \\
8,000\end{array}$ & $\begin{array}{r}2,004 \\
12,000\end{array}$ & $\begin{array}{r}2,672 \\
16,000\end{array}$ & $\begin{array}{r}3,340 \\
20,000\end{array}$ \\
\hline $\begin{array}{l}\text { Merluza } \\
\text { Fish Meal \& Oil }\end{array}$ & $\begin{array}{l}\text { TNR } \\
Q\end{array}$ & $\begin{array}{r}1,230 \\
10,000\end{array}$ & $\begin{array}{r}2,460 \\
20,000\end{array}$ & $\begin{array}{r}3,690 \\
30,000\end{array}$ & $\begin{array}{r}4,920 \\
40,000\end{array}$ & $\begin{array}{r}6,150 \\
50,000\end{array}$ \\
\hline $\begin{array}{l}\text { Congrio } \\
\text { Fresh }\end{array}$ & $\begin{array}{c}\text { TNR } \\
Q\end{array}$ & $\begin{array}{l}233 \\
500\end{array}$ & $\begin{array}{r}396 \\
1,000\end{array}$ & $\begin{array}{r}480 \\
1,500\end{array}$ & $\begin{array}{r}512 \\
2,000\end{array}$ & 2,500 \\
\hline $\begin{array}{l}\text { Congrio } \\
\text { Froze: }\end{array}$ & $\begin{array}{c}\text { TINR } \\
Q\end{array}$ & $\begin{array}{r}68 \\
400\end{array}$ & $\begin{array}{l}136 \\
300\end{array}$ & 1,200 & 1,600 & 2,000 \\
\hline $\begin{array}{l}\text { Congrio } \\
\text { Fish ilieal \& Oil }\end{array}$ & $\begin{array}{c}\text { TNR } \\
Q\end{array}$ & $\begin{array}{r}1,230 \\
10,000\end{array}$ & $\begin{array}{r}2,460 \\
20,000\end{array}$ & $\begin{array}{r}3,600 \\
30,000\end{array}$ & $\begin{array}{l}4,927 \\
40,000\end{array}$ & $\begin{array}{r}0,1,00 \\
50,000\end{array}$ \\
\hline
\end{tabular}


arveritzo (Cont.)

\begin{tabular}{|c|c|c|c|c|c|c|}
\hline Commodity & & Segment 1 & Segment 2 & Segment 3 & Segment 4 & Segment 5 \\
\hline $\begin{array}{l}\text { Merluza de Cola } \\
\text { Frozen }\end{array}$ & $\begin{array}{c}\mathrm{TNR} \\
\mathrm{Q}\end{array}$ & $\begin{array}{r}440 \\
4,000\end{array}$ & $\begin{array}{r}880 \\
8,000\end{array}$ & $\begin{array}{r}1,320 \\
12,000\end{array}$ & $\begin{array}{r}1,760 \\
16,000\end{array}$ & $\begin{array}{r}2,200 \\
20,000\end{array}$ \\
\hline $\begin{array}{l}\text { Merluza de Cola } \\
\text { Fish Meal \& Oil }\end{array}$ & $\underset{Q}{T N}$ & $\begin{array}{r}1,230 \\
10,000\end{array}$ & $\begin{array}{r}2,460 \\
20,000\end{array}$ & $\begin{array}{r}3,690 \\
30,000\end{array}$ & $\begin{array}{r}4,920 \\
40,000\end{array}$ & $\begin{array}{r}6,150 \\
50,000\end{array}$ \\
\hline $\begin{array}{l}\text { Other Demersal } \\
\text { Fresh }\end{array}$ & $\begin{array}{c}\text { TNR } \\
Q\end{array}$ & $\begin{array}{r}336 \\
3,000\end{array}$ & $\begin{array}{r}672 \\
6,000\end{array}$ & $\begin{array}{l}1,008 \\
9,000\end{array}$ & $\begin{array}{r}1,344 \\
12,000\end{array}$ & $\begin{array}{r}1,680 \\
15,000\end{array}$ \\
\hline $\begin{array}{l}\text { Other Demersal } \\
\text { Frozen }\end{array}$ & $\begin{array}{c}\text { TNR } \\
Q\end{array}$ & $\begin{array}{r}286 \\
4,000\end{array}$ & $\begin{array}{r}536 \\
8,000\end{array}$ & $\begin{array}{r}804 \\
12,000\end{array}$ & $\begin{array}{r}1,072 \\
16,000\end{array}$ & $\begin{array}{r}1,340 \\
20,000\end{array}$ \\
\hline $\begin{array}{l}\text { Other Demersal } \\
\text { Fish Meal \& Oil }\end{array}$ & $\begin{array}{c}\mathrm{TNR} \\
\mathrm{Q}\end{array}$ & $\begin{array}{r}1,230 \\
10,000 \\
\end{array}$ & $\begin{array}{r}2,460 \\
20,000 \\
\end{array}$ & $\begin{array}{r}3,690 \\
30,000 \\
\end{array}$ & $\begin{array}{r}4,920 \\
40,000 \\
\end{array}$ & $\begin{array}{r}6,150 \\
50,000 \\
\end{array}$ \\
\hline
\end{tabular}


A resiz: - Total Net Revenue (in US $\$$ x 103) and Associated Outputs (in INT/YR) For Zonal Production of Selected Fishery Commodities

\begin{tabular}{|c|c|c|c|c|c|c|}
\hline & & & Zone $\mathrm{V}$ & & & \\
\hline Commodity & & Segment I & Segment 2 & Segment 3 & Segment 4 & Segment 5 \\
\hline $\begin{array}{l}\text { Anchoveta } \\
\text { Canned }\end{array}$ & $\begin{array}{c}\text { TNR } \\
Q\end{array}$ & $\begin{array}{l}1,137 \\
3,000\end{array}$ & $\begin{array}{l}1,026 \\
6,000\end{array}$ & $\begin{array}{r}-2,241 \\
9,000\end{array}$ & $\begin{array}{l}-8,028 \\
12,000\end{array}$ & $\begin{array}{r}-16,335 \\
15,000\end{array}$ \\
\hline $\begin{array}{l}\text { Anchoveta } \\
\text { Fish Meal \& Oil }\end{array}$ & $\begin{array}{c}\text { TNR } \\
Q\end{array}$ & $\begin{array}{r}6,150 \\
50,000\end{array}$ & $\begin{array}{r}12,300 \\
100,000\end{array}$ & $\begin{array}{r}18,450 \\
150,000\end{array}$ & $\begin{array}{r}24,600 \\
200,000\end{array}$ & $\begin{array}{r}30,750 \\
250,000\end{array}$ \\
\hline $\begin{array}{l}\text { Jurel } \\
\text { Fresh }\end{array}$ & $\begin{array}{c}\text { TNR } \\
Q\end{array}$ & $\begin{array}{r}-42 \\
1,000\end{array}$ & $\begin{array}{r}-144 \\
2,000\end{array}$ & $\begin{array}{r}-306 \\
3,000\end{array}$ & $\begin{array}{r}-528 \\
4,000\end{array}$ & $\begin{array}{r}-310 \\
5,000\end{array}$ \\
\hline $\begin{array}{l}\text { Jurel } \\
\text { Frozen }\end{array}$ & $\begin{array}{c}\text { TNR } \\
Q\end{array}$ & $\begin{array}{r}10 \\
5,000\end{array}$ & $\begin{array}{r}20 \\
10,000\end{array}$ & $\begin{array}{r}30 \\
15,000\end{array}$ & $\begin{array}{r}40 \\
20,000\end{array}$ & $\begin{array}{r}50 \\
25,000\end{array}$ \\
\hline $\begin{array}{l}\text { Jurel } \\
\text { Canned }\end{array}$ & $\begin{array}{c}\text { TNR } \\
Q\end{array}$ & $\begin{array}{l}1,137 \\
3,000\end{array}$ & $\begin{array}{l}1,026 \\
6,000\end{array}$ & $\begin{array}{r}-2,241 \\
9,000\end{array}$ & $\begin{array}{l}-8,028 \\
12,000\end{array}$ & $\begin{array}{r}-16,335 \\
15,000\end{array}$ \\
\hline $\begin{array}{l}\text { Jurel } \\
\text { Fish ileal \& Oil }\end{array}$ & $\begin{array}{l}\text { TNR } \\
Q\end{array}$ & $\begin{array}{r}1,230 \\
10,000\end{array}$ & $\begin{array}{r}2,460 \\
20,000\end{array}$ & $\begin{array}{r}3,690 \\
30,000\end{array}$ & $\begin{array}{r}4,920 \\
40,000\end{array}$ & $\begin{array}{r}6,750 \\
50,000\end{array}$ \\
\hline $\begin{array}{l}\text { Sardina } \\
\text { Fresh }\end{array}$ & $\begin{array}{c}\text { TNR } \\
Q\end{array}$ & 1,000 & 2,000 & $\begin{array}{l}0 \\
3,000\end{array}$ & $\begin{array}{l}0 \\
4,000\end{array}$ & $\begin{array}{c}0 \\
5,000\end{array}$ \\
\hline $\begin{array}{l}\text { Sardina } \\
\text { Canned }\end{array}$ & $\begin{array}{c}\text { TNR } \\
Q\end{array}$ & $\begin{array}{l}1,137 \\
3,000\end{array}$ & $\begin{array}{l}1,026 \\
6,000\end{array}$ & $\begin{array}{r}-2,241 \\
9,000\end{array}$ & $\begin{array}{l}-8,028 \\
12,000\end{array}$ & $\begin{array}{r}-16,335 \\
15,000\end{array}$ \\
\hline $\begin{array}{l}\text { Sardina } \\
\text { Fish Neal \& Oil }\end{array}$ & $\begin{array}{c}\text { TNR } \\
Q\end{array}$ & $\begin{array}{r}1,230 \\
10,000\end{array}$ & $\begin{array}{r}2,460 \\
20,000\end{array}$ & $\begin{array}{r}3,690 \\
30,000\end{array}$ & $\begin{array}{r}4,920 \\
40,000\end{array}$ & $\begin{array}{r}6,150 \\
50,000\end{array}$ \\
\hline
\end{tabular}


apperistro (Cont.)

\begin{tabular}{|c|c|c|c|c|c|c|}
\hline Commodity & & Segment I & Segment 2 & Segment 3 & Segment 4 & Segment 5 \\
\hline $\begin{array}{l}\text { Agujilla } \\
\text { Canned }\end{array}$ & $\begin{array}{c}\text { TNR } \\
Q\end{array}$ & $\begin{array}{l}1,137 \\
3,000\end{array}$ & $\begin{array}{l}\frac{1}{6}, 026 \\
6,000\end{array}$ & $\begin{array}{r}-2,241 \\
9,000\end{array}$ & $\begin{array}{l}-8,028 \\
12,000\end{array}$ & $\begin{array}{r}-16,335 \\
15,000\end{array}$ \\
\hline $\begin{array}{l}\text { Agujilla } \\
\text { Fish Meal \& Oil }\end{array}$ & $\begin{array}{c}\text { TNR } \\
Q\end{array}$ & $\begin{array}{r}1,230 \\
10,000\end{array}$ & $\begin{array}{r}2,460 \\
20,000\end{array}$ & $\begin{array}{r}3,690 \\
30,000\end{array}$ & $\begin{array}{r}4,920 \\
40,000\end{array}$ & $\begin{array}{r}6,150 \\
50,000\end{array}$ \\
\hline $\begin{array}{l}\text { Other Pelagic } \\
\text { Fresh }\end{array}$ & $\begin{array}{l}\text { TNR } \\
Q\end{array}$ & $\begin{array}{r}114 \\
3,000\end{array}$ & $\begin{array}{r}228 \\
6,000\end{array}$ & $\begin{array}{r}342 \\
9,000\end{array}$ & $\begin{array}{r}456 \\
12,000\end{array}$ & $\begin{array}{r}570 \\
15,000\end{array}$ \\
\hline $\begin{array}{l}\text { Other Pelagic } \\
\text { Canned }\end{array}$ & $\begin{array}{l}\text { TNR } \\
Q\end{array}$ & $\begin{array}{l}1,137 \\
3,000\end{array}$ & $\begin{array}{l}1,026 \\
6,000\end{array}$ & $\begin{array}{r}-2,241 \\
9,000\end{array}$ & $\begin{array}{l}-8,028 \\
12,000\end{array}$ & $\begin{array}{r}-16,335 \\
15,000\end{array}$ \\
\hline $\begin{array}{l}\text { Other Pelagic } \\
\text { Fish MeaI \& Oil }\end{array}$ & $\begin{array}{c}\text { TNR } \\
Q\end{array}$ & $\begin{array}{r}1,230 \\
10,000\end{array}$ & $\begin{array}{r}2,460 \\
20,000\end{array}$ & $\begin{array}{r}3,690 \\
30,000\end{array}$ & $\begin{array}{r}4,920 \\
40,000\end{array}$ & $\begin{array}{r}6,150 \\
50,000\end{array}$ \\
\hline $\begin{array}{l}\text { Merluza } \\
\text { Fresh }\end{array}$ & $\begin{array}{c}\text { TNR } \\
Q\end{array}$ & $10,000^{-5}$ & 20,000 & $\begin{array}{r}-120 \\
30,000\end{array}$ & $\begin{array}{r}-280 \\
40,000\end{array}$ & $\begin{array}{r}-625 \\
50,000\end{array}$ \\
\hline $\begin{array}{l}\text { Merluza } \\
\text { Frozen }\end{array}$ & $\begin{array}{c}\text { TNR } \\
Q\end{array}$ & $\begin{array}{r}668 \\
4,000\end{array}$ & $\begin{array}{l}1,336 \\
8,000\end{array}$ & $\begin{array}{r}2,004 \\
12,000\end{array}$ & $\begin{array}{r}2,672 \\
16,000\end{array}$ & $\begin{array}{r}334 \\
20,000\end{array}$ \\
\hline $\begin{array}{l}\text { I.ierluza } \\
\text { Fish Ileal }\end{array}$ & $\begin{array}{c}\mathrm{TNR} \\
\mathrm{Q}\end{array}$ & $\begin{array}{r}1,230 \\
10,000\end{array}$ & $\begin{array}{r}2,460 \\
20,000\end{array}$ & $\begin{array}{r}3,690 \\
30,000\end{array}$ & $\begin{array}{r}4,920 \\
40,000\end{array}$ & $\begin{array}{r}0,150 \\
50,000\end{array}$ \\
\hline $\begin{array}{l}\text { Congrio } \\
\text { Fresh }\end{array}$ & $\begin{array}{l}\text { TINR } \\
Q\end{array}$ & $\begin{array}{l}217 \\
500\end{array}$ & $\begin{array}{r}364 \\
1,000\end{array}$ & $\begin{array}{r}441 \\
1,500\end{array}$ & $\begin{array}{r}443 \\
2,000\end{array}$ & $\begin{array}{r}385 \\
2,500\end{array}$ \\
\hline $\begin{array}{l}\text { Congrio } \\
\text { Frozer }\end{array}$ & $\begin{array}{l}\text { TNR } \\
Q\end{array}$ & $\begin{array}{r}63 \\
400\end{array}$ & $\begin{array}{l}136 \\
300\end{array}$ & $\begin{array}{r}204 \\
1,207\end{array}$ & $\begin{array}{r}272 \\
1,620\end{array}$ & 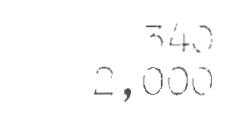 \\
\hline $\begin{array}{l}\text { Congrio } \\
\text { Fish Ivieal \& Oil }\end{array}$ & $\begin{array}{c}\text { TNRR } \\
Q\end{array}$ & $\begin{array}{r}1,230 \\
10,000\end{array}$ & $\begin{array}{r}2,400 \\
20,000\end{array}$ & $\begin{array}{l}7,600 \\
=0,000\end{array}$ & $\begin{array}{l}4,020 \\
40,002\end{array}$ & $\begin{array}{l}0,152 \\
50,002\end{array}$ \\
\hline
\end{tabular}




\section{Appenaix J- (Cont.)}

\begin{tabular}{|c|c|c|c|c|c|c|}
\hline Commodity & & Segment 1 & Segment 2 & Segment 3 & Segment 4 & Segment 5 \\
\hline $\begin{array}{l}\text { Merluza de Cola } \\
\text { Frozen }\end{array}$ & $\begin{array}{c}\text { TNR } \\
Q\end{array}$ & $\begin{array}{r}440 \\
4,000\end{array}$ & $\begin{array}{r}880 \\
8,000\end{array}$ & $\begin{array}{r}1,320 \\
12,000\end{array}$ & $\begin{array}{r}1,760 \\
16,000\end{array}$ & $\begin{array}{r}2,220 \\
20,000\end{array}$ \\
\hline $\begin{array}{l}\text { Merluza de Cola } \\
\text { Fish Meal \& Oil }\end{array}$ & $\begin{array}{c}\text { TNR } \\
Q\end{array}$ & $\begin{array}{r}1,230 \\
10,000\end{array}$ & $\begin{array}{r}2,460 \\
20,000\end{array}$ & $\begin{array}{r}3,690 \\
30,000\end{array}$ & $\begin{array}{r}4,920 \\
40,000\end{array}$ & $\begin{array}{r}6,150 \\
50,000\end{array}$ \\
\hline $\begin{array}{l}\text { Other Demersal } \\
\text { Fresh }\end{array}$ & $\begin{array}{c}\mathrm{TNR} \\
\mathrm{Q}\end{array}$ & $\begin{array}{r}240 \\
3,000\end{array}$ & $\begin{array}{r}480 \\
6,000\end{array}$ & $\begin{array}{r}720 \\
9,000\end{array}$ & $\begin{array}{r}960 \\
12,000\end{array}$ & $\begin{array}{r}1,200 \\
15,000\end{array}$ \\
\hline $\begin{array}{l}\text { Other Demersal } \\
\text { Frozen }\end{array}$ & $\begin{array}{c}\text { TNR } \\
Q\end{array}$ & $\begin{array}{r}286 \\
4,000\end{array}$ & $\begin{array}{r}536 \\
8,000\end{array}$ & $\begin{array}{r}804 \\
12,000\end{array}$ & $\begin{array}{r}1,072 \\
16,000\end{array}$ & $\begin{array}{r}1,340 \\
20,000\end{array}$ \\
\hline $\begin{array}{l}\text { Other Demersal } \\
\text { Fish Meal \& Oil }\end{array}$ & $\underset{Q}{T N R}$ & $\begin{array}{r}1,230 \\
10,000\end{array}$ & $\begin{array}{r}2,460 \\
20,000\end{array}$ & $\begin{array}{r}3,690 \\
30,000\end{array}$ & $\begin{array}{r}4,920 \\
40,000\end{array}$ & $\begin{array}{r}6,150 \\
50,000\end{array}$ \\
\hline
\end{tabular}


aprenżi E- Separable Programming Results: Summary of Annual Outputs by Commodity (MT/YR) Alternative A - Zonal Objective Functions

\begin{tabular}{|c|c|c|c|c|c|c|c|c|c|}
\hline & & & & ear & & & & & \\
\hline Commodity & 1 & 2 & 3 & 4 & 5 & 6 & 7 & 8 & 9 \\
\hline $\begin{array}{l}1 \text { Canned Anch } \\
2 \text { Anch FM }\end{array}$ & $\begin{array}{l}10,820 \\
79,040\end{array}$ & $\begin{array}{r}14,890 \\
165,500\end{array}$ & $\begin{array}{l}12,220 \\
56,600\end{array}$ & $\begin{array}{r}11,810 \\
118,300\end{array}$ & $\begin{array}{c}0 \\
202.700\end{array}$ & $\frac{0}{97.180}$ & $\begin{array}{r}805 \\
110.300\end{array}$ & $\begin{array}{c}0 \\
194.000\end{array}$ & $\frac{0}{208.600}$ \\
\hline 3 Fresh Jr. S. & 5,231 & 5,000 & 6,913 & $\frac{1+0,000}{15,000}$ & $\frac{20,100}{25,000}$ & $\frac{91,2,00}{25,000}$ & $\frac{1 \pm, 2,00}{25,000}$ & $\frac{174,000}{25,000}$ & $\frac{20,0,000}{25,000}$ \\
\hline 4 Frozen Jr. S & $\frac{251}{0}$ & $\frac{2000}{0}$ & $\frac{0}{1212}$ & $\frac{12,000}{0}$ & $\frac{2,00}{0}$ & $\frac{2,000}{0}$ & $\frac{2,200}{0}$ & $\frac{2,200}{0}$ & $\frac{c 2000}{0}$ \\
\hline $\begin{array}{l}5 \text { Canned J.S. } \\
6 \text { Jr.S.FM }\end{array}$ & 6,597 & 4,523 & $0^{7,158}$ & 8,551 & 3,998 & 1,000 & 4,630 & 2,889 & 2,491 \\
\hline 7 Fresh Sara & 7,00 & 5,000 & 5,000 & 9,282 & 10,780 & 11,380 & 11,070 & 12,000 & 11,490 \\
\hline $\begin{array}{l}8 \text { Canned Sard } \\
9 \text { Sard FM }\end{array}$ & $\begin{array}{l}18,080 \\
25,630\end{array}$ & $\begin{array}{l}15,970 \\
12,270\end{array}$ & $\begin{array}{r}15,400 \\
9,719\end{array}$ & 15,180 & $\begin{array}{r}6,298 \\
21,250\end{array}$ & $\frac{1}{6}, 920$ & $\begin{array}{l}13,100 \\
14,300\end{array}$ & $\begin{array}{r}5,189 \\
19,630\end{array}$ & $\begin{array}{r}4,791 \\
13.280\end{array}$ \\
\hline 10 Cai:.ned Agu & $\frac{2,200}{0}$ & $\frac{125}{0}$ & $\frac{0}{21+2}$ & $\frac{12}{0}$ & 29,470 & 36,850 & 21,230 & 31,690 & 32,480 \\
\hline $11 \mathrm{Agu} \mathrm{FM}$ & 0 & 0 & 0 & 0 & 8,230 & 18,880 & 4,377 & 9,424 & 9,853 \\
\hline 12 OPF Fresh & 14,150 & 7.001 & 11,350 & 8,081 & 30,600 & 11,650 & 27,520 & 13,830 & 24,590 \\
\hline 13 OPF Canned & 907 & 449 & 727 & 518 & 0 & 0 & $\frac{1}{0}$ & 0 & 0 \\
\hline 14 OPF Fish Meal & 8,161 & 4.039 & 6,541 & 4,662 & 8.126 & 3,093 & 7,308 & 3,686 & 6,529 \\
\hline 15 Fresh Merluza & 549 & 674 & 553 & 243 & 197 & 2,716 & 2,402 & 1,228 & 1,000 \\
\hline 16 Frozen Merluza & 9,031 & 9,010 & 8,941 & 9,094 & 8,790 & 8,790 & 8,790 & 8,790 & 8,790 \\
\hline 17 MZA FM & 11.490 & 6,517 & 3,089 & 19.660 & 20,440 & 12,120 & 13,830 & 18,370 & 14,530 \\
\hline 18 Fresh Cong & 2,754 & 2,791 & 2,755 & 2,663 & 4,485 & 6,225 & 5,869 & 5,016 & 5,951 \\
\hline 19 Frozen Cong & 109 & 115 & 109 & 95 & 400 & 400 & 400 & 400 & 400 \\
\hline 20 Cong FM & 0 & 0 & 0 & 0 & 0 & 330 & 186 & 0 & 1,352 \\
\hline 21 Frozen MdeC & 0 & O & $\overline{0}$ & $\overline{0}$ & $\overline{0}$ & 0 & 0 & 0 & 0 \\
\hline 22 ilice FM & 0 & 0 & 0 & 0 & 4,855 & 3,959 & 4,219 & 5,405 & 6,676 \\
\hline 23 ODF Fresh & 879 & 922 & 2,576 & 927 & 16,020 & 16,810 & 13,880 & 10,640 & 13,150 \\
\hline 24 ODF Frozen & 251 & 263 & & & & & & & \\
\hline 25 ODF Fish Meal & 0 & 0 & 0 & 0 & 0 & 0 & 0 & 0 & 0 \\
\hline Subtotals & & & & & & & & & \\
\hline $\begin{array}{l}\text { Fresh } \\
\text { Frozen } \\
\text { Canned } \\
\text { Fish Meal }\end{array}$ & $\begin{array}{r}30,563 \\
9,441 \\
36,404 \\
124,321\end{array}$ & $\begin{array}{r}21,388 \\
9,388 \\
35,832 \\
.183,326\end{array}$ & $\begin{array}{r}29,137 \\
9,786 \\
35,505 \\
75,949\end{array}$ & $\begin{array}{r}36,196 \\
9,455 \\
36059 \\
159,712\end{array}$ & $\begin{array}{r}87,032 \\
9,657 \\
39,766 \\
265,601\end{array}$ & $\begin{array}{r}73,781 \\
9,890 \\
38,770 \\
142,150\end{array}$ & $\begin{array}{r}85,741 \\
9,763 \\
39,765 \\
154,410\end{array}$ & $\begin{array}{c}67,764 \\
9,663 \\
45,763 \\
250,565\end{array}$ & $\begin{array}{r}81,181 \\
9,738 \\
29,762 \\
260,820\end{array}$ \\
\hline
\end{tabular}




\begin{tabular}{|c|c|c|c|c|c|c|c|c|c|}
\hline Commodity & 7 & 2 & 3 & Year & 5 & 6 & 7 & 8 & 9 \\
\hline I Canned Anch & $\frac{1}{10,820}$ & 14,890 & 12,220 & $\frac{4}{11,810}$ & $\frac{3}{0}$ & 0 & 804 & $\frac{8}{0}$ & $y$ \\
\hline 2 Anch FM & 79,040 & 105,500 & 56.500 & 113,300 & 202,700 & 97,130 & 110,300 & 194,000 & 208,600 \\
\hline 3 Fresh Jr. S. & 5,231 & 5,000 & 6,913 & 15,000 & 25,000 & 25,000 & 25,000 & 25,000 & 25,000 \\
\hline $\begin{array}{l}4 \text { Frozen Jr.S. } \\
5 \text { Canned J.S. } \\
6 \text { Jr.S.FM }\end{array}$ & 6,597 & $\begin{array}{l}0 \\
4,523 \\
0\end{array}$ & $\theta^{0}, 158$ & 8,551 & 3,998 & 1,000 & $4_{0}^{0}, 630$ & 2,889 & 2,491 \\
\hline 7 Fresh Sard & 7,000 & 5,000 & 5,000 & 9,282 & 10,780 & 11,330 & 11,070 & 12,000 & 11,490 \\
\hline $\begin{array}{l}8 \text { Canned Sard } \\
9 \text { Sard FM }\end{array}$ & $\begin{array}{l}18,030 \\
25,630\end{array}$ & $\begin{array}{l}15,970 \\
12,270\end{array}$ & $\begin{array}{r}15,400 \\
9,719\end{array}$ & $\begin{array}{l}15,180 \\
17,090\end{array}$ & $\begin{array}{r}6,298 \\
21,250\end{array}$ & $\begin{array}{l}1,920 \\
6.594\end{array}$ & $\begin{array}{l}13,100 \\
14,300\end{array}$ & $\begin{array}{r}5,189 \\
19.680\end{array}$ & $\begin{array}{r}4,791 \\
13.280\end{array}$ \\
\hline $\begin{array}{l}10 \text { Canned Agu } \\
11 \text { Agu FN }\end{array}$ & $\begin{array}{l}-20 \\
0 \\
0\end{array}$ & $\begin{array}{l}0 \\
0 \\
0\end{array}$ & $\begin{array}{l}0 \\
0\end{array}$ & $\frac{1+170}{0}$ & $\begin{array}{r}29,470 \\
8,230\end{array}$ & $\begin{array}{l}36,850 \\
18,8860\end{array}$ & 21,230 & 31,690 & 32,480 \\
\hline 12 OPF Fresh & 14,150 & 7,001 & 11,340 & 8,081 & 30,600 & 11,650 & 27,520 & 13,880 & 24,590 \\
\hline 13 OPF Canned & 907 & 449 & 729 & 518 & 0 & 0 & 0 & 0 & 0 \\
\hline 14 OPF Fish Meal & 8,161 & 4,039 & 6,541 & $4, \overline{662}$ & 8,126 & 3,093 & 7,308 & 3,686 & 5,529 \\
\hline 15 Fresh Merluza & 549 & 674 & 553 & 243 & 197 & 2,716 & 2,402 & 1,228 & 1,000 \\
\hline $\begin{array}{l}16 \text { Frozen Merluza } \\
17 \text { MZA FM }\end{array}$ & $\begin{array}{r}908 \\
11,490\end{array}$ & $\begin{array}{l}9,010 \\
6,517\end{array}$ & $\begin{array}{l}8,941 \\
3,089\end{array}$ & $\begin{array}{r}9,094 \\
19,660\end{array}$ & $\begin{array}{r}8,790 \\
20,440\end{array}$ & $\begin{array}{r}8,790 \\
12,120\end{array}$ & $\begin{array}{r}8,790 \\
13,830\end{array}$ & $\begin{array}{r}8,790 \\
18,370\end{array}$ & $\begin{array}{r}8,790 \\
14,530\end{array}$ \\
\hline 18 Fresh Cong & 2,754 & 2,791 & 2,755 & 2,663 & 4,485 & 6,225 & 5,869 & 5,016 & 5,951 \\
\hline 19 Frozen Cong & 109 & 115 & 109 & 96 & 400 & 400 & 400 & 400 & 400 \\
\hline 20 Cong FN & 0 & 0 & 0 & 0 & 0 & 330 & 186 & 0 & 1,352 \\
\hline 21 Frozen MideC & $\overline{0}$ & 0 & $\overline{0}$ & 0 & $\overline{0}$ & 0 & 0 & $\overline{0}$ & 0 \\
\hline 22 MdeC FM & D & 0 & 0 & 0 & 4,855 & 3,959 & 4,219 & 5,405 & 6,676 \\
\hline 23 ODF Fresh & 879 & 922 & 2,576 & 927 & 16,020 & 16,810 & 13.8 .30 & 10,640 & 13,150 \\
\hline 24 ODF Frozen & 251 & 263 & 736 & & & & & & \\
\hline 25 ODF Fish Meal & 0 & 0 & 0 & 0 & 0 & 0 & 0 & 0 & 0 \\
\hline $\begin{array}{l}\text { Subtotals } \\
\text { Fresh } \\
\text { Frozen } \\
\text { Cain.ad } \\
\text { Fish Meal }\end{array}$ & $\begin{array}{r}30,563 \\
9,441 \\
36,404 \\
124,321\end{array}$ & $\begin{array}{r}21,388 \\
9,388 \\
35,832 \\
189,326\end{array}$ & $\begin{array}{r}29,137 \\
9,786 \\
35,505 \\
75,949\end{array}$ & $\begin{array}{r}36,196 \\
9,455 \\
36,059 \\
159,712\end{array}$ & $\begin{array}{r}87,082 \\
9,857 \\
39,766 \\
265,601\end{array}$ & $\begin{array}{r}73,731 \\
9,390 \\
33,770 \\
142,150\end{array}$ & $\begin{array}{r}35,741 \\
9,768 \\
39,765 \\
154,420\end{array}$ & $\begin{array}{r}67,764 \\
9,663 \\
45,763 \\
250,565\end{array}$ & $\begin{array}{r}81,181 \\
9,738 \\
20,762 \\
260,320\end{array}$ \\
\hline
\end{tabular}




\begin{tabular}{|c|c|c|c|c|c|c|c|c|c|c|c|}
\hline Alt. $A$ & $\mathrm{NR}^{\mathrm{ZO}}$ & $\begin{array}{l}\text { I } \\
\text { ROI }\end{array}$ & $\mathrm{NR}^{\text {Zon }}$ & II & $N^{Z}$ & $\begin{array}{l}\text { III } \\
\text { ROI }\end{array}$ & ZR & $\begin{array}{l}\text { IV } \\
\text { ROI }\end{array}$ & $N^{\text {Zor }}$ & $\begin{array}{l}\text { V } \\
\text { ROI }\end{array}$ & $\begin{array}{c}\text { National } \\
\text { NR }\end{array}$ \\
\hline $\begin{aligned} & \text { Year } \\
& 2 \\
& 3 \\
& 4 \\
& 4 \\
& 6 \\
& 7 \\
& 8 \\
& 9 \\
& 10\end{aligned}$ & $\begin{array}{l}25,630 \\
25,630 \\
13,000 \\
20,000 \\
37,000 \\
28,000 \\
24,000 \\
37,000 \\
39,000 \\
38,000\end{array}$ & $\begin{array}{l}14 \\
22 \\
11 \\
17 \\
32 \\
23 \\
21 \\
31 \\
33 \\
32\end{array}$ & $\begin{array}{l}2,345 \\
2,345 \\
2,300 \\
3,100 \\
9,400 \\
9,200 \\
8,400 \\
9,200 \\
9,600 \\
9,500\end{array}$ & $\begin{array}{l}31 \\
28 \\
15 \\
20 \\
61 \\
60 \\
55 \\
60 \\
62 \\
62\end{array}$ & $\begin{array}{l}15,390 \\
15,390 \\
15,000 \\
18,000 \\
25,000 \\
23,000 \\
21,000 \\
24,000 \\
24,000 \\
23,000\end{array}$ & $\begin{array}{l}32 \\
27 \\
27 \\
33 \\
44 \\
42 \\
38 \\
43 \\
43 \\
41\end{array}$ & $\begin{array}{r}31 \\
31 \\
35 \\
30 \\
7,20 \\
7,00 \\
6,60 \\
7,00 \\
7,30 \\
7,40\end{array}$ & $\begin{array}{r}9 \\
7 \\
3 \\
2 \\
57 \\
56 \\
52 \\
55 \\
57 \\
58\end{array}$ & $\begin{array}{r}42 \\
42 \\
69 \\
49 \\
3,000 \\
2,700 \\
2,900 \\
2,500 \\
3,300 \\
3,000\end{array}$ & $\begin{array}{l}8 \\
4 \\
2 \\
1 \\
67 \\
62 \\
65 \\
57 \\
74 \\
67\end{array}$ & $\begin{array}{l}43,730 \\
43,730 \\
30,880 \\
41,730 \\
81,560 \\
69,860 \\
63,250 \\
79,510 \\
83,000 \\
80,900\end{array}$ \\
\hline
\end{tabular}

\begin{tabular}{|c|c|c|c|c|c|c|c|c|c|c|c|}
\hline $\begin{array}{r}1 \\
2 \\
3 \\
4 \\
5 \\
6 \\
7 \\
8 \\
9 \\
10\end{array}$ & $\begin{array}{l}16,000 \\
26,000 \\
13,000 \\
20,000 \\
37,000 \\
28,000 \\
24,000 \\
27,000 \\
39,000 \\
38,000\end{array}$ & $\begin{array}{r}14 \\
22 \\
8 \\
12 \\
23 \\
17 \\
15 \\
22 \\
24 \\
23\end{array}$ & $\begin{array}{l}2,600 \\
2,300 \\
2,300 \\
3,100 \\
9,400 \\
9,200 \\
8,400 \\
9,200 \\
9,600 \\
9,500\end{array}$ & $\begin{array}{r}31 \\
23 \\
5 \\
7 \\
21 \\
20 \\
19 \\
20 \\
21 \\
21\end{array}$ & $\begin{array}{l}18,000 \\
15,000 \\
15,000 \\
18,000 \\
25,000 \\
23,000 \\
21,000 \\
24,000 \\
24,000 \\
23,000\end{array}$ & $\begin{array}{l}32 \\
27 \\
15 \\
18 \\
24 \\
23 \\
21 \\
24 \\
23 \\
23\end{array}$ & $\begin{array}{r}380 \\
310 \\
350 \\
300 \\
7,200 \\
7,000 \\
6,600 \\
7,000 \\
7,300 \\
7,400\end{array}$ & $\begin{array}{l}9 \\
7 \\
1 \\
7 \\
30 \\
30 \\
28 \\
20 \\
30 \\
31\end{array}$ & $\begin{array}{r}86 \\
43 \\
69 \\
49 \\
3,000 \\
2,700 \\
2,900 \\
2,500 \\
3,300 \\
3,000\end{array}$ & $\begin{array}{l}8 \\
4 \\
0.2 \\
0.2 \\
10 \\
9 \\
10 \\
8 \\
11 \\
10\end{array}$ & $\begin{array}{l}37,240 \\
43,730 \\
30,880 \\
41,730 \\
81,560 \\
69,860 \\
63,250 \\
79,510 \\
83,030 \\
80,903\end{array}$ \\
\hline
\end{tabular}

